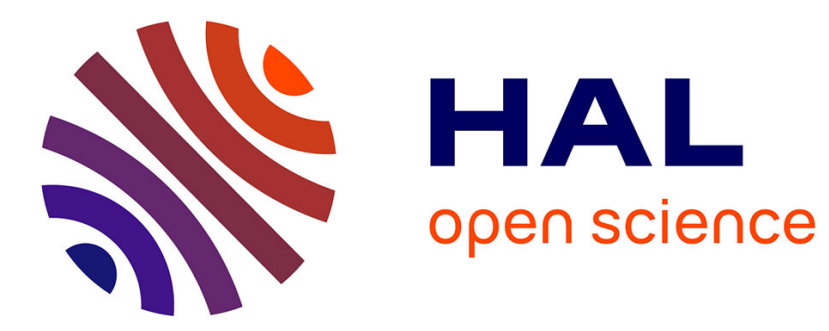

\title{
Multi-stage crustal growth and Neoarchean geodynamics in the Eastern Dharwar Craton, southern India
}

\author{
M. Jayananda, K.R. R Aadhiseshan, Monika A Kusiak, Simon A Wilde, \\ Kowete-U Sekhamo, Martin Guitreau, M. Santosh, R.V. V Gireesh
}

\section{- To cite this version:}

M. Jayananda, K.R. R Aadhiseshan, Monika A Kusiak, Simon A Wilde, Kowete-U Sekhamo, et al.. Multi-stage crustal growth and Neoarchean geodynamics in the Eastern Dharwar Craton, southern India. Gondwana Research, 2020, 78, pp.228-260. 10.1016/j.gr.2019.09.005 . hal-03153546

\author{
HAL Id: hal-03153546 \\ https://hal.uca.fr/hal-03153546
}

Submitted on 26 Feb 2021

HAL is a multi-disciplinary open access archive for the deposit and dissemination of scientific research documents, whether they are published or not. The documents may come from teaching and research institutions in France or abroad, or from public or private research centers.
L'archive ouverte pluridisciplinaire HAL, est destinée au dépôt et à la diffusion de documents scientifiques de niveau recherche, publiés ou non, émanant des établissements d'enseignement et de recherche français ou étrangers, des laboratoires publics ou privés. 
1 GR Focus Review

2

3

4

5

6 M.Jayananda $^{1 *}$, K.R. Aadhiseshan ${ }^{1,2}$, Monika A. Kusiak ${ }^{3}$, Simon A. Wilde $^{4}$, Kowete-u 7 Sekhamo $^{2,5}$, M. Guitreau ${ }^{6}$, M. Santosh ${ }^{7}$, R.V. Gireesh ${ }^{8}$

\section{Multi-stage crustal growth and Neoarchean geodynamics in the Eastern Dharwar Craton, Southern India}

1. Centre for Earth, Ocean and Atmospheric Sciences, University of Hyderabad, Hyderabad - 500 046, India

2. Department of Geology, University of Delhi, Delhi - 110 007, India

3. Institute of Geophysics, Polish Academy of Sciences, Księcia Janusza 64, PL-01452 Warsaw, Poland

4. School of Earth and Planetary Sciences, Curtin University, PO Box U1987, Perth, WA 6845, Australia

5. Department of Geology, Patkai Christian College, Dimapur-797103, India

6. Université Clermont Auvergne, Laboratoire Magmas et Volcans, IRD, CNRS, UMR 6524, 6 Avenue Blaise Pascal, 63178 Aubière, France

7. School of Earth Sciences and Resources, China University of Geosciences Beijing, 29 Xueyuan Road, Beijing 100083, China

8. Department of Mines and Geology, Government of Karnataka, Mysore, India

*Corresponding author

E-mail address: mjayan.geol@gmail.com 


\section{Abstract}

The Dharwar Craton is a composite Archean cratonic collage that preserves important records of crustal evolution on the early Earth. Here we present results from a multidisciplinary study involving field investigations, petrology, zircon SHRIMP U-Pb geochronology with in-situ $\mathrm{Hf}$ isotope analyses, and whole-rock geochemistry, including $\mathrm{Nd}$ isotope data on migmatitic TTG (tonalite-trondhjemite-granodiorite) gneisses, dark grey banded gneisses, calc-alkaline and anatectic granitoids, together with synplutonic mafic dykes along a wide Northwest Southeast corridor forming a wide time window in the Central and Eastern blocks of the Dharwar Craton. The dark grey banded gneisses are transitional between TTGs and calcalkaline granitoids, and are referred to as 'transitional TTGs', whereas the calc-alkaline granitoids show sanukitoid affinity. Our zircon $\mathrm{U}-\mathrm{Pb}$ data, together with published results, reveal four major periods of crustal growth (ca. 3360-3200 Ma, 3000-2960 Ma, 2700-2600 $\mathrm{Ma}$ and 2570-2520 Ma) in this region. The first two periods correspond to TTG generation and accretion that is confined to the western part of the corridor, whereas widespread 26702600 transitional TTG, together with a major outburst of 2570-2520 Ma juvenile calcalkaline magmatism of sanukitoid affinity contributed to peak continental growth. The transitional TTGs were preceded by greenstone volcanism between 2746-2700 Ma, whereas the calc-alkaline magmatism was contemporaneous with 2570-2545 Ma felsic volcanism. The terminal stage of all four major accretion events was marked by thermal events reflected by amphibolite to granulite facies metamorphism at ca. $3200 \mathrm{Ma}, 2960 \mathrm{Ma}, 2620 \mathrm{Ma}$ and $2520 \mathrm{Ma}$. Elemental ratios $\left.\left[(\mathrm{La} / \mathrm{Yb})_{\mathrm{N}}, \mathrm{Sr} / \mathrm{Y}, \mathrm{Nb} / \mathrm{Ta}, \mathrm{Hf} / \mathrm{Sm}\right)\right]$ and $\mathrm{Hf}-\mathrm{Nd}$ isotope data suggest that the magmatic protoliths of the TTGs emplaced at different time periods formed by melting of thickened oceanic arc crust at different depths with plagioclase + amphibole \pm garnet + titanite/ilmenite in the source residue, whereas the elemental $\left(\mathrm{Ba}-\mathrm{Sr},\left[(\mathrm{La} / \mathrm{Yb})_{\mathrm{N}}\right.\right.$, $\mathrm{Sr} / \mathrm{Y}, \mathrm{Nb} / \mathrm{Ta}, \mathrm{Hf} / \mathrm{Sm})]$ and $\mathrm{Hf}-\mathrm{Nd}$ isotope data $\left[\varepsilon^{-\mathrm{Hf}_{(\mathrm{T})}}=-0.67\right.$ to $5.61 ; \varepsilon \mathrm{Nd}_{(\mathrm{T})}=0.52$ to $\left.4.23 ;\right]$ of the transitional TTGs suggest that their protoliths formed by melting of composite sources involving mantle and overlying arc crust with amphibole + garnet + clinopyroxene \pm plagioclase + ilmenite in the residue. The highly incompatible and compatible element contents (REE, K-Ba-Sr, $\mathrm{Mg}, \mathrm{Ni}, \mathrm{Cr}$ ), together with $\mathrm{Hf}$ and $\mathrm{Nd}$ isotope data $\left[\mathrm{\varepsilon Hf}_{(\mathrm{T})}=4.5\right.$ to $3.2 ; \varepsilon \mathrm{Nd}_{(\mathrm{T})}=1.93$ to $-1.26 ;$; , of the sanukitoids and synplutonic dykes suggest their derivation from enriched mantle reservoirs with minor crustal contamination. Field, elemental and isotope data $\left[\varepsilon \mathrm{EH}_{(\mathrm{T})}=-4.3\right.$ to $-15.0 ; \varepsilon \mathrm{Nd}_{(\mathrm{T})}=-0.5$ to -7.0$]$ of the anatectic granites suggest their derivation through reworking of ancient as well as newly formed juvenile crust. Secular increase in incompatible as well as compatible element contents in the transitional TTGs to sanukitoids imply progressive enrichment of Neoarchean mantle reservoirs, possibly through melting of continent-derived detritus in a subduction zone setting, resulting in the establishment of a sizable continental mass by $2700 \mathrm{Ma}$, which in turn is linked to the evolving Earth. The Neoarchean geodynamic evolution is attributed to westward convergence of hot oceanic lithosphere, with continued convergence resulted in the assembly of microblocks, with eventual slab break-off leading to asthenosphere upwelling caused extensive mantle melting and hot juvenile magma additions to the crust. This led to lateral flow of hot ductile crust and 3D mass distribution and formation of an orogenic plateaux with subdued topography, as indicated by strain fabric data and strong seismic reflectivity along an E-W crustal profile in the Central and Eastern blocks of the Dharwar Craton.

Key words: Dharwar Craton; Zircon U-Pb geochronology; Lu-Hf-Sm-Nd isotopes; Crustal evolution; Archean Earth. 


\section{Contents}

1. Introduction

2. Regional geological framework of the Dharwar Craton

3. Geological setting of the study area

3.1 Central block

3.2 Eastern block

4. Petrography

5. Zircon $\mathrm{U}-\mathrm{Pb}$ geochronology and in situ $\mathrm{Hf}$ isotopes

5.1 Central block

5.1.1 Migmatitic gneisses and transitional TTGs

5.1.2 Calc-alkaline granitoids

5.2 Eastern block

5.2.1 Transitional TTGs and diatexites

5.2.2 Calc-alkaline granitoids

6. Whole-rock geochemistry

6.1 Major and trace elements

6.2 Zircon in-situ Hf isotopes and whole-rock Nd isotopes

7. Discussion

7.1 Effects of secondary processes on elemental compositions

7.2 Petrogenesis and sources

7.2.1 Ca.3360-3000 Ma Migmatitic TTGs

7.2.2 Ca. 2670-2600 Ma Transitional TTGs

7.2.3 Ca. 2570-2535 Ma Sanukitoids

7.2.4 Ca. 2535 Ma Synplutonic mafic dykes

7.2.5 Ca. 2535-2520 Ma anatectic granites

7.3 Multi-stage crust accretion, continental growth and reworking

7.4 Mantle evolution through the Neoarchean: Implications for enrichment of source reservoirs

7.4.1 Constraints from greenstone volcanism (2746-2670 Ma)

7.4.2 Constraints from transitional TTGs (2670-2600 Ma) and sanukitoids (2570$2520 \mathrm{Ma}$ )

7.5 Evolving geodynamic processes through the Neoarchean: implications for assembly of crustal blocks, orogenic plateau formation and cratonization

8. Conclusions

Acknowledgements

References

108

109

\section{Introduction}

The Archean witnessed major periods of juvenile crustal accretion, continental growth and craton formation (Goodwin, 1996; Hawkesworth et al., 2010; Dhuime et al., 2012; Condie et al., 2014). Models proposed for continental growth suggest that 60-70 percent of the preserved continental crust on our globe formed by $2500 \mathrm{Ma}$ (e.g. Armstrong and Harmon, 1981; Reymer and Schubert, 1984; Cawood et al., 2013; Hawkesworth et al., 2013; Taylor 
and McLennan, 1995; Dhuime et al., 2018). During the past two decades, attention has been focused on the changes in petrogenetic, thermal and tectonic processes involved in the differentiation of crust from the mantle and the transformation of newly-formed juvenile crust into Archean cratons (e.g. Martin et al., 2005; Mueller et al., 2010; Chardon et al., 2009; Moyen, 2011; Spencer et al., 2017; Jayananda et al., 2018; Korenaga, 2018). The Archean cratons were constructed by episodic juvenile accretion, recycling of pre-existing crustal materials and assembly of micro-blocks through multiple collisions (e.g. Manikyamba et al., 2017; Roberts and Santosh, 2018; Jayananda et. al., 2018; Li et al., 2018a). However, the tectonic context of crustal accretion remains equivocal, with debates on stagnant lid, through vertical accretion associated with plumes, to modern-style horizontal tectonic processes (Choukroune et al., 1997; Smithies et al., 2005; Bedard, 2006, 2013; Dhuime et al 2012; Gerya, 2014; Sizova et al., 2015; Kamber et al., 2015; Brown and Johnson, 2018; Cawood et al., 2018; Jayananda et al., 2018; Moyen and Laurent, 2018). Despite significant advances in our understanding of the timing and mechanisms of major Archean craton building processes, secular changes in the compositions of juvenile additions, as well as the tectonic context of Archean continental growth, are still topics of debate. In this context, the Dharwar Craton forms an ideal target as it consists of a large tilted panel of pristine Archean crust preserving a wide time window (3600-2500 Ma) to address coupled evolution of the crust-mantle system, secular changes in petrogenetic and geodynamic processes and craton formation. Several integrated studies have contributed significantly to our understanding of the fundamental architecture, time-frame of crustal accretion and reworking, as well as petrogenetic processes (Chardon et al., 2008, 2011; Dey et al., 2016; Jayananda et al., 2013a,b, 2015; Guitreau et al., 2017; Manikyamba et al., 2017; Wang and Santosh, 2019 and references therein). More recent studies have shown that the Dharwar Craton formed by assembly of micro-blocks with independent crustal histories (Jayananda et al., 2018; Roberts and Santosh, 2018; Li et al., 2018a). However, the role of juvenile accretion and ancient crustal reworking in Archean continental growth and craton building processes in individual blocks is not precisely known, as most of the studies focussed on either greenstone volcanism (Manikyamba and Kerrich, 2012; Jayananda et al., 2013b; Khanna et al., 2014, 2016; Yang et al., 2015; Dey et al., 2018) or surrounding granitoids (Dey et al., 2012, 2014, 2015). However, integrated studies on the age zonation patterns of the gneisses and granitoids, as well as their spatial/temporal relationship with volcanism in the adjoining greenstone belts and crust-mantle evolution through the Neoarchean, are rather limited. Furthermore, the geodynamic context of crust formation and craton building processes are hotly debated, 
especially between horizontal tectonics involving westward convergence of hot orogenic crust (Chardon et al., 2011; Dey et al., 2016) or eastward subduction (Bidyananda et al., 2016; Santosh and Li, 2018), or even plume (or combined plume-arc) models (Jayananda et al., 2013a, 2018; Manikyamba et al., 2012). Consequently, the main purpose of this contribution is to address the timing and relative roles of juvenile crust addition versus reworking of Archean continental crust, the evolving petrogenetic and geodynamic processes and craton building through integrated field and petrographic studies, U-Pb zircon geochronology together with in-situ Hf isotope analyses, whole-rock geochemistry and $\mathrm{Nd}$ isotopes. For this, we selected basement gneisses and granitoids along a wide corridor in the Central and Eastern blocks of the Dharwar Craton from Hangal in the northwest to Madanapalle to the southeast (Fig. 1), corresponding to different crustal levels.

\section{Regional geological framework of the Dharwar Craton}

The Dharwar Craton (Fig. 1) has been traditionally divided into two cratonic blocks, namely the western and eastern craton, based on lithological associations, metamorphic grade and crustal thickness (Swami Nath et al., 1976; Gupta et al., 2003; Jayananda et al., 2006; Chardon et al., 2008). The boundary between these two crustal blocks was marked by the steep mylonitic zone along the eastern boundary of the Chitradurga greenstone belt. However, recent studies consider that the craton is composed of three distinct blocks, namely the Western, Central and Eastern based on the age of the basement rocks, distinct thermal records and accretionary histories (Peucat et al., 2013; Jayananda et al., 2013a,2018; Dey,2013; Li et al., 2018a,b). The Western block extends from the Arabian Sea to the eastern boundary of the Chitradurga greenstone belt and contains the oldest nucleus with 3400-3200 Ma TTG-greenstone assemblages that record two major pre-2500 Ma thermal events at ca. 3100-3000 Ma and $2620 \mathrm{Ma}$ and record local reworking that resulted in the emplacement of high-K granites (Chardon et al., 2011; Jayananda et al., 2006, 2013a, 2015, 2019). The Central Dharwar block extends from the Chitradurga boundary shear zone (see Fig. 1) to the western boundary of the Kolar - Kadiri-Penakacherla - Kushtagi-Hungund greenstone belts, and comprises a mix of ca. 3400-3000 Ma and 2700-2500 Ma crust that was affected by two pre-2500 Ma thermal events at ca. $3200 \mathrm{Ma}$ and $2620 \mathrm{Ma}$ (Jayananda et al. 2011, 2013a). The Eastern Dharwar block extends eastward from the above-mentioned greenstone belts to the Cuddapah Basin and Eastern Ghats Mobile Belt and contains mainly 2700-2530 Ma crust that was affected by only the $2500 \mathrm{Ma}$ thermal event, which commonly overprinted the whole of the Archean crust in the Dharwar Craton (Peucat et al., 2013; Jayananda et al., 2013a). 
Overall, the Dharwar Craton (Fig. 1) is a composite collage of Archean crustal blocks that form a large tilted panel of pristine crust that evolved during a wide time window (3800-2500 Ma; (Jayananda et al., 2018 and references therein). The major lithological assemblages include different types of gneisses, two generations of greenstone sequences and calc-alkaline to potassic granitoid plutons. Recent studies have shown that the Dharwar Craton formed by assembly of several micro-blocks (Santosh et al., 2015; Jayananda et al., 2018; Roberts and Santosh, 2018; Li et al., 2018a,b). The polyphase gneisses are the most voluminous lithologies and show large variations in mineralogy, chemical composition, timing of emplacement of their protoliths (3600-2600 Ma), indicating they were affected by multiple thermal events (Balakrishnan et al., 1999; Chardon et al., 2011; Moyen et al., 2003; Jayananda et al., 2013a, 2015, 2018; Dey et al., 2016; Peucat et al., 2013). The greenstone sequences are divided into the older Sargur Group and younger Dharwar Supergroup (Swami Nath et al., 1981). The Sargur Group greenstone sequences, together with interlayered tonalite-trondhjemite-granodiorite (TTG) gneisses, form the basement for the younger Dharwar Supergroup greenstones. The two stratigraphically distinct greenstone sequences are separated by angular unconformities (Ramakrishnan et al., 1976; Venkata Dasu et al., 1991; Chardon et al., 1996). The older Sargur Group is dominated by ultramafic-mafic volcanics of komatiite lineage that are interlayered with quartzite-pelite-carbonate-BIF (Banded Iron Formation) units. Whole-rock $\mathrm{Sm}-\mathrm{Nd}$ isochrons for komatiites display ages in the range of 3384-3150 Ma (Jayananda et al., 2008; Maya et al., 2017), whereas the associated felsic volcanics record SHRIMP U-Pb zircon ages of ca. 3300 Ma (Peucat et al., 1995). Detrital zircons from quartzites and pelites indicate ages in the range of ca. 3600-3230 Ma (Nutman et al., 1992; Hokada et al., 2013; Lancaster et al., 2015; Wang and Santosh, 2019). In contrast, the younger Dharwar Supergroup comprises ca. 3000-2740 Ma old greenstone sequences unconformably overlying the basement (TTG/Sargur Group) and forming the vast Bababudan-Chitradurga-Dharwar basins in the western part of the craton (Fig. 1). These greenstone sequences are dominated by mafic to felsic volcanics with interlayered conglomerate-quartzite-carbonate-greywacke-argillite-BIF sequences (Chadwick et al., 1981, 1985; Srinivasan and Ojakangas, 1986; Kumar et al., 1996; Jayananda et al., 2013b). The greenstone basins in the eastern part of the craton with dominant volcanic sequences (KolarKadiri; Ramagiri-Penakacherla; Sandur; Gadwal-Narayanapet; Jonnagiri; Veligallu) show bimodal age distributions at ca. 2750-2670 Ma and 2580-2545 Ma (Naqvi et al., 2002; Manikyamba and Kerrich, 2012; Manikyamba et al., 2004, 2008, 2009, 2014, 2017; Jayananda et al., 2013b; Dey et al., 2015,2018; Khanna et al., 2014,2016). Calc-alkaline to 
potassic granitoids mark the terminal events of craton building in the Dharwar Craton. At least three major episodes (ca. $3000 \mathrm{Ma}, 2620$-2580 Ma and 2560-2520 Ma) of granitoid emplacement are related to the craton forming events (Chardon et al., 2011; Jayananda et al., 2006, 2018, 2019). The 3000 Ma high-K plutons intrude into TTG-Sargur Group greenstone sequences in the Western Dharwar Craton (WDC; Chardon et al., 2011; Jayananda et al., 2019) whereas the ca. 2620-2580 Ma potassic granites form discrete plutons which intrude into either TTG basement or the basement-Dharwar Supergroup greenstone interface (Jayananda et al., 2006; Chadwick et al., 2007; Sarma et al., 2012; Mohan et al., 2014). In contrast, the 2560-2520 Ma granitoid plutons are restricted to the Central and Eastern Dharwar craton and are regional in extent, forming major juvenile crustal accretions and marking the final stage of cratonization (Jayananda et al., 2013a, 2018; Anand et al., 2014; Dey et al., 2014, 2016). These granitoids are composite plutons comprising mostly voluminous sanukitoids, with a minor component of anatectic granites (Peucat et al., 1993; Harish Kumar et al., 2003; Jayananda et al., 1995, 2000; Balakrishnan et al., 1999; Moyen et al., 2003a; Rogers et al., 2007; Dey et al., 2012, 2014, 2016).

231 On the cratonic scale, LANDSAT-TM data, together with our field-based fabric mapping, 232 reveal dome and basin patterns, steep north-trending foliations, flat foliations and regional strike-slip shear zones (Chardon et al., 2008). The Western Dharwar Craton displays ca. 3200 Ma dome and basin patterns resulting from forces linked to inverse density stratification associated with high-density greenstone loading on the low-density infracrustal basement (Bouhallier et al., 1993, 1995; Chardon et al., 1996, 2008). The whole craton was involved in Neoarchean crustal-scale regional shear deformation, reflected in widely-spaced shear zones in the western part and closely-spaced shear zones in the eastern part. However, in the eastern part (central and eastern blocks) conjugate shear zone patterns result from interference between the two shear systems: a NE trending dextral shear system in the south and a sinistral WNW trending shear system in the north (Chadwick et al., 2000, 2007; Chardon et al., 2008). This shear deformation event is sub-contemporaneous with the emplacement of 2560-2520 Ma granitoid plutons and culminated with 2500 Ma regional metamorphism followed by slow cooling until $2450 \mathrm{Ma}$ (Chadwick et al., 2000; Chardon et al., 2002; 2008, 2011; Peucat et al., 1993, 2013; Jayananda and Mahabaleswar, 1991; Jayananda et al., 2013a). The cratonized Archean basement was later intruded by Paleoproterozoic to Mesoproterozoic mafic dyke swarms (Srivastava et al., 2014a; Soderlund et al., 2018).

\section{3. Geological setting of the study area}


The studied crustal corridor (Hangal - Madanapalle) exposes a tilted NW-SE section of preserved Archean crust that includes both the Central and Eastern blocks (Fig. 2). The major lithological assemblages include different generations of gneisses with remnants of highgrade supracrustal rocks, volcanic-sedimentary greenstone sequences and composite calcalkaline granitoid intrusions. In this study, the gneisses and granitoids of the Central and Eastern blocks are described separately with their distinct thermal records and crustal histories (Jayananda et al., 2013a).

\subsection{Central block}

The part of the studied corridor located in the Central block extends from the Chitradurga boundary shear zone to the Kadiri-Kolar greenstone belt (Fig.2) and is composed of migmatitic TTGs (Chardon et al., 2011; Jayananda et al., 2000, 2013a; Nasheeth et al., 2016; Bidyananda et al., 2016), dark grey banded transitional TTGs, the Penukonda-RamagiriPenakacherla greenstone belt and voluminous north-south trending composite granitoid intrusions, including the Closepet granite, the Lepakshi-Bukkapatnam massifs and plutons extending further east up to the Kadiri greenstone belt (Fig. 2). The migmatitic TTGs occur as discontinuous outcrops and are abundant to the west of the Closepet granite. They are also found as large screens along the boundary of the Closepet batholith (Fig. 3a) but are scanty towards the eastern part of the central block. These migmatitic TTGs are weakly foliated and comprise dark grey tonalite, grey granodiorite and whitish grey trondhjemite that commonly is injected by granitoid veins or sheets. They are traversed by melt-filled dextral shear bands. The TTGs are locally interlayered with high-grade supracrustal enclaves dominated by pelitequartzite-carbonate, with minor amphibolites. Migmatized pelitic rocks contain large sillimanite crystals rimmed by spinel-quartz and traversed by melt-filled shears (Fig.3b). Published detrital zircon data of the metapelites record ages as old as 3360 Ma for their crustal provenance (Jayananda et al., 2013a). The P-T-t estimates, together with in-situ monazite ages, reveal metamorphism close to ultra-high temperature $\left(850^{\circ} \mathrm{C}\right.$ at $\left.5-7 \mathrm{kbar}\right)$ conditions at ca. $2620 \mathrm{Ma}$, with an earlier amphibolite facies event at ca. $3140 \mathrm{Ma}$ (Jayananda et al., 2011).

The dark grey banded gneisses are the most voluminous lithologies and they commonly contain leucocratic veins with hornblende crystals developed along flat to shallow foliations. The shallow foliations progressively become steep close to the large granitoid intrusions (e.g. the Closepet batholith) and shear zones (Fig. 3c). Locally, melt-filled dextral shears traverse 
dark grey banded gneisses that contain clinopyroxene crystals (Fig. 3d). Preliminary petrographic and geochemical studies of the dark grey banded gneisses reveal their transitional character between TTGs and sanukitoids and are therefore referred to as 'transitional TTGs' (Jayananda et al., 2006, 2018; Dey et al., 2016). A dark grey hornblenderich quartz monzonite intrusion into migmatitic gneisses, known as the 'Sira gneiss complex' (Fig. 3e), was dated at $2562 \pm 4$ Ma by Chardon et al (2011).

The studied corridor in the Central block contains volcanic-sedimentary greenstone sequences (e.g. Sandur, Penukonda- Ramagiri-Penakacherla greenstone belts) including different types of metabasalts together with intermediate to felsic volcanics and minor interlayered sediments. A Sm-Nd whole rock isochron for the metabasalts from the Sandur greenstone belt records an imprecise age of $2705 \pm 184 \mathrm{Ma}$ (Naqvi et al., 2002), whereas zircon U-Pb ages of the felsic volcanics in the higher stratigraphic levels record ages of 2691$2658 \mathrm{Ma}$ (Nutman et al., 1996). Zachariah et al (1995) reported Pb-Pb ages of $2746 \pm 64 \mathrm{Ma}$ for metabasalts in the central part of the Ramagiri greenstone belt, whereas $\mathrm{U}-\mathrm{Pb}$ zircon dating of felsic volcanics from this belt records an age of $2707 \pm 18 \mathrm{Ma}$ (Balakrishnan et al., 1999).

The granitoid intrusions in the Central block include the $\sim 500 \mathrm{~km}$ long Closepet batholith, which is the largest composite magmatic intrusion in the Dharwar Craton (Jayananda et al., 1995, 2000, 2014; Moyen et al., 2003b) and the study area covers the central part of this batholith (see Fig. 2) corresponding to the zone of accumulation (Moyen et al., 2003b). The batholith contains two major suites of magmatic bodies; the more voluminous darker suite is confined to the core, whereas the minor light pink to grey leucocratic anatectic granites are located along the periphery, where they show diffusive contacts with the basement rocks. The darker suite comprises dark grey quartz monzonite to monzodiorite (Fig. 3f) and porphyritic monzogranite to granodiorite with large K-feldspar phenocrysts (30-40\%) that commonly show NNE to NNW orientation coinciding with the regional foliation (Fig. 3g). The phenocrysts locally exhibit rapakivi-like texture, and rarely orbicular texture. The darker suite contains fragmented synplutonic dykes and mafic magmatic enclaves (MME) that commonly contain small feldspar phenocrysts. The MMEs and synplutonic mafic dykes most likely correspond to late-stage mafic melts or hybrid melts injected into the crystallizing host magma chamber wherein the MMEs form when mafic melts are introduced at the initial stages of crystallization of the host (20-30 \% crystals). The series of aligned MMEs and fragmented synplutonic dykes formed when mafic melts entered into the host magma with 
40-60 \% crystals (Jayananda et al., 2009, 2014; Prabhakar et al., 2009; Gireesh et al., 2012). Fragmented synplutonic dykes in the host granitoids have biotite-rich margins or show magmatic flow fabrics along with their host. In some cases, close to the MMEs and synplutonic mafic dykes, reversal of crystallization of the host granitoid resulted in back veining that can be observed at the outcrop scale.

The light grey to pink anatectic granites occur as veins and large sheets and/or dykes. Locally, gradation from gneisses to anatectic granite can be observed, but most commonly the granites were injected into the gneisses (Fig. 3h) and intrusive relations suggest that these rocks formed by anatexis of the basement at much deeper levels. The anatectic suite locally contains rotated angular mafic to intermediate enclaves with strong fabrics (Fig. 3i) along the shear zones. The anatectic rocks, together with synplutonic mafic dykes, define magmatic flow structures implying injection of mafic melts with contemporaneous emplacement of anatectic magmas (Fig. $3 j$ ). Different stages of interaction between the host granitoid and mafic magma injections suggest magma mixing and mingling.

\subsection{Eastern block}

The part of the studied corridor, located in the Eastern block, comprises dark grey banded gneisses, voluminous migmatitic gneisses of diatexitic nature, volcanic-dominated greenstone sequences (Kadiri and Veligallu) and granitoid intrusions (Fig. 2). The dark grey banded gneisses occur as low outcrops with shallow foliations (Fig. 4a). Diatexitic gneisses are widespread throughout the eastern block and they contain numerous biotite schlieren, mafic xenoliths and screens of mafic gneisses (Fig. 4b). The diatexitic gneisses also show a transition to banded grey gneisses and are locally interlayered with the dark grey banded gneisses (Fig. 4c).

337 The greenstone sequences include the north-south trending Kadiri belt and the Veligallu 338 greenstone belt further east (see Fig. 2). The Kadiri greenstone belt contains mafic to felsic 339 volcanics with minor sediments. Zircon SHRIMP (Sensitive High Resolution Ion 340 Microprobe) $\mathrm{U}-\mathrm{Pb}$ data for the felsic volcanics indicate a bimodal age distribution at $2717 \pm$ $34124 \mathrm{Ma}$ and $2556 \pm 13$, with inherited zircons recording ages of $2970 \mathrm{Ma}$ and $3150 \mathrm{Ma}$ also 342 present (Jayananda et al 2013b). Zircon from a rhyolite in the sequence recorded an age of $3432535 \pm 32 \mathrm{Ma}$ (Dey et al., 2015). The Veligallu greenstone belt contains minor ultramafic 344 volcanic rocks with abundant mafic and felsic volcanics. Zircon SHRIMP U-Pb dating of the 345 felsic volcanics yielded an age of $2692 \pm 5$ Ma (Jayananda et al. 2013b) and a similar age of 
$2696 \pm 54$ Ma was obtained by a subsequent whole rock Lu-Hf isotope isochron on the ultramafic volcanics (Khanna et al., 2016).

The granitoid plutons consist of quartz monzonite, monzodiorite, porphyritic monzogranite, and granodiorite and are surrounded by anatectic pink to light grey granite and by voluminous diatexites. Locally, angular fragments or boudins of quartz monzonite/monzodiorite and porphyritic monzogranite are found in the diatexites (Fig. 4c). Dark grey hornblende-rich monzodiorite occurs as discontinuous outcrops that contain mafic magmatic enclaves. The light pink to whitish grey anatectic rocks commonly contains mafic enclaves, fragments of banded grey gneisses and biotite schlieren. They locally show magmatic flow fabrics with fragments of other granitoids (Fig. 4e). At several outcrops, the anatectic rocks contain MME. As an example, a spectacular roadside outcrop (1 km south of Tanakallu along the Kadiri Madanapalle road) displays anatectic granite containing numerous MME /hybrid enclaves where different stages of interaction, mixing, mingling and hybridization are visible (Fig. 4f). A large quarry near Madanapalle exposes both intrusive granitoids and anatectic granites and diatexites with numerous mafic enclaves where titanite crystal accumulation is observed in the anatectic granite. Numerous northwest-trending quartz reefs traverse the granitoid massifs and these are present only in the eastern block, probably related to the final differentiated silica-rich liquids injected into the crystallized plutons.

364 The studied corridor displays spectacular flat to shallow fabrics which progressively become 365 steeper toward shear zones. Several N10-30 ${ }^{\circ}$ E trending melt-filled ductile shear zones, together 366 with $\mathrm{N} 10-40^{\circ} \mathrm{W}$ trending sinistral shear zones, define interference shear zone patterns 367 (Chadwick et al., 2000; Jayananda et al., 2006; Chardon et al., 2008, 2011). These interfering shear zones are not confined to the margins of the granitoid plutons, but also cross-cut the plutons that contain numerous angular mafic to ultramafic xenoliths, possibly transported from the lower crust or mantle. In summary, the studied corridor exposes a tilted panel of Archean continental crust with different lithological assemblages displaying shallow to steep fabrics and with interfering shear zone patterns, thus forming a complex crustal architecture (Fig. 5)

\section{Petrography}

The migmatitic gneisses of the Central block are medium- to coarse-grained and contain quartz, sodic plagioclase (An $12-15$ ), minor microcline and biotite, with accessory zircon, apatite and opaque Fe-Ti oxides (Fig. 6a). The banded dark grey to grey gneisses (transitional TTG) contain 
quartz, more calcic plagioclase ( $\left.\mathrm{An}_{15-28}\right)$, microcline, abundant hornblende (Fig. 6b) and biotite, with accessory zircon, apatite, titanite and opaque minerals.

The quartz monzonite contains quartz, plagioclase $\left(\mathrm{An}_{15-26}\right)$, abundant microcline, hornblende, biotite (Fig. 6c), and local clinopyroxene, with accessory zircon, apatite, titanite, allanite and opaque minerals. The porphyritic monzogranites are coarse-grained and display a bimodal grain size with large alkali feldspar phenocrysts set in a quartz-feldspar matrix (Fig. 6d). The accessory zircon, apatite, titanite, allanite and opaque minerals occur together and form clusters with the mafic minerals. Plagioclase $\left(\mathrm{An}_{15-18}\right)$ shows crude zoning, whereas Potassium feldspar is mainly microcline that is locally mantled by plagioclase, implying magma mingling.

The fragmented synplutonic dykes are fine- to medium-grained and contain small alkali feldspar phenocrysts. The mineral assemblage consists of variable proportions of plagioclase $\left(\mathrm{An}_{20-32}\right)$ and microcline and abundant hornblende and biotite, with some clinopyroxene and minor quartz (Fig. 6e). Accessory minerals include zircon, large apatite needles, titanite and opaque minerals.

390 The anatectic granite is medium- to coarse-grained and has a hypidiomorphic granular texture. 391 These rocks contain abundant quartz and microcline, with subordinate plagioclase $\left(\mathrm{An}_{10-12}\right)$ and 392 biotite (Fig. 6f). Locally, the anatectic granites contain large crystals of hornblende that are 393 commonly replaced by biotite. The accessory minerals are zircon, apatite, titanite and opaques 394 that commonly occur together as clusters.

395 In the Eastern block, the banded gneisses are medium- to coarse-grained with a dominant 396 mineral assemblage of quartz, plagioclase $\left(\mathrm{An}_{15-26}\right)$, microcline, hornblende, and biotite, with 397 accessory zircon, apatite and opaque minerals (Fig. 7a). The plutons of quartz monzonite to 398 monzodiorite contain quartz, sub-equal plagioclase $\left(\mathrm{An}_{15-28}\right)$ and microcline, hornblende, biotite 399 (Fig. $7 b)$, whereas the porphyritic varieties contain quartz, plagioclase $\left(\mathrm{An}_{14-23}\right)$, and abundant microcline (Fig. 7c), with accessory zircon, apatite, titanite, and opaque minerals. The anatectic granite and diatexite are medium- to coarse-grained with mafic minerals defining a magmatic foliation. The mineral assemblage includes quartz, microcline, sodic plagioclase $\left(\mathrm{An}_{12-15}\right)$, biotite, and local hornblende, with accessory zircon, titanite, and opaque minerals (Fig. 7d). In summary, the intrusive rocks in the Central block are more voluminous and contain abundant hornblende, with local clinopyroxene, when compared to the intrusive rocks in the Eastern block. The anatectic rocks are more abundant in the Central block, whereas diatexites are more common in the Eastern block. 


\section{Zircon U-Pb geochronology and in situ Hf isotopes}

The SHRIMP U-Pb isotope data for zircon grains from migmatitic gneisses, transitional TTGs, sanukitoids and anatectic granites analysed in this study are presented in Supplementary table 1. In-situ $\mathrm{Hf}$ isotope data of the corresponding zircons analysed for $\mathrm{U}-\mathrm{Pb}$ are presented in Supplementary table 2. Details of the analytical methods are presented in the Appendix.

\subsection{Central block}

\subsubsection{Migmatitic and Transitional TTGs}

Sample EDC-TTG $\left(14^{\circ} 39^{\prime} 10^{\prime \prime} \mathrm{N} ; 7^{\circ} 40^{\prime} 45^{\prime \prime} \mathrm{E}\right)$-Migmatitic tonalitic gneiss

The tonalitic rocks in the migmatitic TTG were collected $\sim 40 \mathrm{~km}$ north of Challakere town in Bellary road (adjacent to telecom tower, see Fig. 2). Prismatic zircon crystals with pyramidal terminations mostly reveal oscillatory zoning in cathodoluminescence (CL) images. Most grains show discordant truncated growth zoning in cores, probably corresponding to dissolution. Analyses were performed on prismatic grains with or without oscillatory zoning. They have low $\mathrm{U}(129-481 \mathrm{pm})$ and Th (62-462 ppm) contents, with Th/U ratios ranging from 0.10 to 1.10 , suggesting a magmatic origin. The results are discordant, with an upper intercept ${ }^{207} \mathrm{~Pb} /{ }^{206} \mathrm{~Pb}$ age of $3271 \pm 5 \mathrm{Ma}$ with MSWD = 1.3 (Fig. 8.1a), corresponding to the time of crystallization.

Zircons record ${ }^{176} \mathrm{Hf} /{ }^{177} \mathrm{Hf}$ ratios varying from 0.28073 to $0.28088, \varepsilon \mathrm{Hf}_{(\mathrm{T})}$ values of +0.6 to +5.4 which were calculated using their corresponding SHRIMP zircon U-Pb age of $3271 \mathrm{Ma}$. Depleted mantle model ( $\left.\mathrm{T}_{\mathrm{DM}}\right)$ ages range between 3594-3321 Ma $\left(\mathrm{T}_{\mathrm{DM} 1}\right)$ and two-stage model ages $\left(\mathrm{T}_{\mathrm{DM} 2}\right)$ between 3474-3301 Ma.

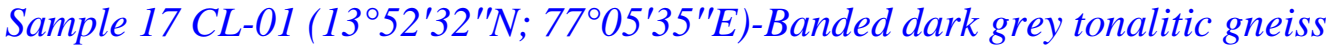

This sample was collected along the western boundary of the Closepet batholith about $3 \mathrm{~km}$ north of Rolla (Fig. 2). Zircon crystals from sample 17CL01 are elongated, euhedral, and most exhibit well-defined oscillatory zoning typical of a magmatic origin. Some brighter domains resembling metamorphic recrystallization can also be seen within a few of the analyzed crystals, together with darker domains that likely result from local radiation-damage-induced metamictization. No overgrowths or core-rim relationships are visible in the analyzed crystals. The zircons contain low to high U (98-915 ppm) and Th (24-390 ppm) concentrations, with $\mathrm{Th} / \mathrm{U}$ ratios ranging from 0.11 to 0.57 . A set of 24 analyses define an upper intercept ${ }^{207} \mathrm{~Pb} /{ }^{206} \mathrm{~Pb}$ 
age of $2670 \pm 8 \mathrm{Ma}(\mathrm{MSWD}=1.50)$ corresponding to crystallization of the magmatic precursor of the tonalitic gneiss (Fig. 8.1b).

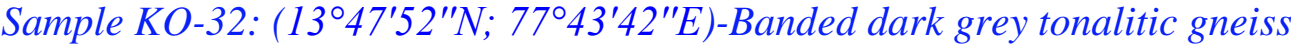

Sample KO-32 was collected $\sim 3 \mathrm{~km}$ south of Lepakshi (Fig. 2). It is a coarse-grained, strongly banded dark grey tonalitic gneiss. CL images of zircon grains reveal elongated euhedral morphology with local recrystallized zones. They contain low to moderate concentrations of $\mathrm{U}(225-728 \mathrm{ppm})$ and Th $(34-420 \mathrm{ppm}$, with a few outliers of very low Th $<5 \mathrm{ppm}$ ) with $\mathrm{Th} / \mathrm{U}$ ratios ranging from 0.16 to 1.21 . A suite of euhedral zircons (12 analyses) is concordant to sub-concordant and defines an upper intercept ${ }^{207} \mathrm{~Pb} /{ }^{206} \mathrm{~Pb}$ age of $2601 \pm 16 \mathrm{Ma}(\mathrm{MSWD}=6.1$, Fig. 8.1c).

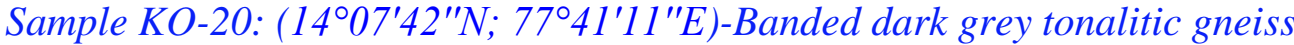

Sample KO-20 was collected $\sim 13 \mathrm{~km}$ west of Puttaparthi (Fig. 2) and is a banded tonalitic gneiss with a shallow foliation. Zircons are euhedral, elongated prismatic grains with aspect ratios of 3:1 or greater. They show concentric zoning typical of magmatic growth, with evidence of recrystallization of the edges locally observed in CL. Small inclusions of apatite are present. The zircons are characterized by moderate to high contents of $U$ (300-1018 ppm) and Th (152-495 ppm, with few low values <16 ppm) and low Th/U ratios (0.24-0.55), indicative of a magmatic origin. A set of twenty-two zircons define an upper intercept ${ }^{207} \mathrm{~Pb} /{ }^{206} \mathrm{~Pb}$ age of $2600 \pm 11 \mathrm{Ma}$. The weighted mean ${ }^{207} \mathrm{~Pb} /{ }^{206} \mathrm{~Pb}$ age calculated from the concordant data is $2595 \pm 15(11 / 22$ analyses, MSWD=8.9) (Fig. 8.1d).

In-situ $\mathrm{Hf}$ isotope analysis of zircons record ${ }^{176} \mathrm{Hf} /{ }^{177} \mathrm{Hf}_{(\mathrm{T})}$ ratios ranging from 0.28121 to 0.28140 , with $\varepsilon \mathrm{Hf}_{(\mathrm{T})}$ values of +7.8 to +3.6 calculated on the $\mathrm{U}-\mathrm{Pb}$ zircon age of $2600 \mathrm{Ma}$. Depleted mantle model $\left(\mathrm{T}_{\mathrm{DM}}\right)$ ages range from 2878-2620 Ma $\left(\mathrm{T}_{\mathrm{DM} 1}\right)$ and two-stage model $\left(\mathrm{T}_{\mathrm{DM} 2}\right)$ ages from 2779-2611 Ma.

\subsubsection{Calc-alkaline granitoids}

\section{Sample PAV-VES-1a $\left(14^{\circ} 06^{\prime} 27^{\prime \prime} N ; 7^{\circ} 17^{\prime} 19^{\prime \prime}\right.$ E)-Porphyritic monzogranite}

Sample PAV-VES-1a is a coarse-grained porphyritic monzogranite collected from a large quarry in the north-eastern outskirts of Pavagada town (Fig. 2). The zircon CL images display euhedral to subhedral morphology with concentric zoning locally overgrown by unzoned zircon. They have low to high U (154-1821 ppm) and Th (75-1042 ppm) contents, with Th/U 
ratios ranging from 0.20-1.26, indicative of magmatic crystallization. A set of 24 analyses define an upper intercept ${ }^{207} \mathrm{~Pb} /{ }^{206} \mathrm{~Pb}$ age of $2546 \pm 8 \mathrm{Ma}(\mathrm{MSWD}=0.93)$ that corresponds to the crystallization age of the porphyritic monzogranite (Fig. 8.2a).

In-situ $\mathrm{Hf}$ isotope analysis of zircons from sample PAV-VES1a record ${ }^{176} \mathrm{Hf} /{ }^{177} \mathrm{Hf}(\mathrm{T})$ ratios ranging from 0.28101 to 0.28116 , with corresponding $\varepsilon \mathrm{Hf}_{(\mathrm{T})}$ values ranging from +0.5 to -6.1 calculated at the U-Pb age of $2546 \mathrm{Ma}$. Depleted mantle $\left(\mathrm{T}_{\mathrm{DM}}\right)$ model ages range from $3100-$ $2847 \mathrm{Ma}\left(\mathrm{T}_{\mathrm{DM} 1}\right)$ and 3032-3433 Ma $\left(\mathrm{T}_{\mathrm{DM} 2}\right)$.

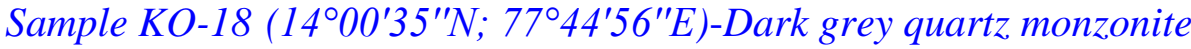

Sample KO-18 was collected from an abandoned quarry $\sim 3 \mathrm{~km}$ north of Kodikonda (Fig. 2). It is a coarse-grained dark grey monzogranite with phenocrysts of alkali feldspar. Zircons show prismatic and pyramidal forms with concentric zoning typical of growth from a magma. Evidence for recrystallization can be observed locally (e.g. section 3.1). The $\mathrm{U}$ and $\mathrm{Th}$ contents and Th/U ratios are range between 166-368 ppm, 105-337 ppm and 0.34-0.80, respectively. Uranium- $\mathrm{Pb}$ data are discordant and 4 analyses define an upper intercept ${ }^{207} \mathrm{~Pb} /{ }^{206} \mathrm{~Pb}$ age of $2526 \pm 13 \mathrm{Ma}(\mathrm{MSWD}=0.43$, Fig. 8.2b).

Zircons from this quartz monzonite record ${ }^{176} \mathrm{Hf} /{ }^{177} \mathrm{Hf}$ ratios ranging from 0.28119 to 0.28135 and $\varepsilon \mathrm{Hf}_{(\mathrm{T})}$ values ranging from +1.1 to +1.8 at the corresponding age of $2526 \mathrm{Ma}$. The depleted mantle $\left(\mathrm{T}_{\mathrm{DM}}\right)$ model ages are in the range of 2882-2693 $\left(\mathrm{T}_{\mathrm{DM} 1}\right)$ and 3092-2760 Ma $\left(\mathrm{T}_{\mathrm{DM} 2}\right)$.

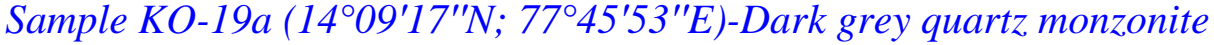

This sample was collected from an abandoned quarry $\sim 2 \mathrm{~km}$ west Puttaparthi (Fig. 2). It is a coarse-grained, dark grey rock that is affected by shearing. Zircon grains have a doublyterminated prismatic morphology with narrow concentric zones. They record $\mathrm{U}$ and $\mathrm{Th}$ contents and $\mathrm{Th} / \mathrm{U}$ ratios in the range of 101-774 ppm, 79-307 ppm, and 0.16-0.90, respectively. A set of euhedral zircons (16/19 analyses) define a discordia with an upper intercept ${ }^{207} \mathrm{~Pb} /{ }^{206} \mathrm{~Pb}$ age of $2573 \pm 8 \mathrm{Ma}(\mathrm{MSWD}=2.4$, Fig. 8.2c) and this is interpreted as the time of crystallization.

The Hf isotope analyses of the zircon grains record ${ }^{176} \mathrm{Hf} /{ }^{177} \mathrm{Hf}$ ratios ranging from 0.28123 to 0.28133 and $\varepsilon \mathrm{Hf}_{(\mathrm{T})}$ values ranging from +3.4 to +6.9 at the corresponding age of $2573 \mathrm{Ma}$. 
496

Depleted mantle $\left(\mathrm{T}_{\mathrm{DM}}\right)$ model ages are in the range of 2747-2610 Ma for $\left(\mathrm{T}_{\mathrm{DM} 1}\right)$ and 2855$2637 \mathrm{Ma}\left(\mathrm{T}_{\mathrm{DM} 2}\right)$.

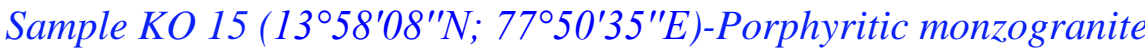

Porphyritic monzogranite was collected $1 \mathrm{~km}$ south of Reddicheruvukatta village along the Kadiri - Kodikonda road (Fig. 2). The sample is a coarse-grained porphyritic monzogranite with cream coloured K-feldspar phenocrysts. Zircon grains are euhedral with oscillatory zoning. They record low to moderate U (76-556 ppm) and Th (49-969 ppm) contents with $\mathrm{Th} / \mathrm{U}$ ratios of $0.20-1.74$, indicating a magmatic origin. Twelve zircons were analysed, and the results are discordant (Fig. 8.2d) defining an upper intercept ${ }^{207} \mathrm{~Pb} /{ }^{206} \mathrm{~Pb}$ age of $2568 \pm 11$ Ma $($ MSWD $=0.46)$, considered to record the time of crystallization.

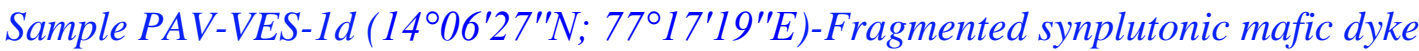

This sample of synplutonic mafic dyke was collected from the same quarry as sample PAVVES-1a (see Fig. 2). The zircons are squat to elongated grains and show oscillatory as well as convolute zoning in CL. They have variable U (75-810 ppm) and Th (42-1386 ppm) concentrations, with $\mathrm{Th} / \mathrm{U}$ values ranging from $0.06-2.19$ indicative of a magmatic origin. The results (17/21 grains) definine an upper intercept ${ }^{207} \mathrm{~Pb} /{ }^{206} \mathrm{~Pb}$ age of $2535 \pm 6 \mathrm{Ma}$ (MSWD =1.14; Fig. 8.2e).

The Hf isotope analyses of zircons from sample PAV-VES1d record ${ }^{176} \mathrm{Hf} /{ }^{177} \mathrm{Hf}_{(\mathrm{T})}$ ratios in the range of 0.28111 to 0.28125 , with $\mathrm{eHf}_{(\mathrm{T})}$ values ranging from +5.0 to -1.6 at the corresponding age of $2535 \mathrm{Ma}$. They indicate depleted mantle ( $\left.\mathrm{T}_{\mathrm{DM} 1}\right)$ model ages of 31212661- Ma and ( $\left.\mathrm{T}_{\mathrm{DM} 2}\right)$ values of 3139-2737 Ma.

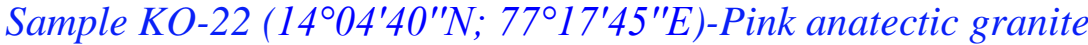

An anatectic pink granite sample was collected from a quarry $\sim 3 \mathrm{~km}$ south of Pavagada along the eastern boundary of the Closepet batholith (Fig. 2). Zircon grains are euhedral to subhedral and are commonly squat with low aspect ratios and partially developed terminal pyramids and pinacoids. Evidence for partial recrystallization includes overgrowths and recrystallized domains in some grains. The grains contain variable contents of U (139-1438 $\mathrm{ppm})$ and Th (21-754 ppm) that result in highly variable Th/U ratios 0.12-2.26. Twenty one zircon analyses display two discordant patterns and define two sets of ages, with the older ${ }^{207} \mathrm{~Pb} /{ }^{206} \mathrm{~Pb}$ data defining an upper intercept age of $3328 \pm 14 \mathrm{Ma}(\mathrm{MSWD}=2.6)$ and the younger ${ }^{207} \mathrm{~Pb} /{ }^{206} \mathrm{~Pb}$ age group defining an upper intercept of $2531 \pm 6 \mathrm{Ma}$ with MSWD=0.93 
527

(Fig. 8.2f). The younger age is interpreted as the time of crystallization of the anatectic melt, whereas the older ${ }^{207} \mathrm{~Pb} /{ }^{206} \mathrm{~Pb}$ age is interpreted to define inherited zircon from the basement incorporated in the melt.

In-situ $\mathrm{Hf}$ isotope analyses of the zircon grains record ${ }^{176} \mathrm{Hf} /{ }^{177} \mathrm{Hf}_{(\mathrm{T})}$ ratios ranging from 0.28066 to 0.28110 and $\varepsilon \mathrm{Hf}_{(\mathrm{T})}$ values ranging from -2.0 to -10.7 at the corresponding age of $2531 \mathrm{Ma}$ and +1.4 to +4.4 for the older grains at $3328 \mathrm{Ma}$. The calculated depleted mantle $\left(\mathrm{T}_{\mathrm{DM}}\right)$ ages range from 4064-3158 Ma.

534 Zircon Hf isotope data reveal ${ }^{176} \mathrm{Hf} /{ }^{177} \mathrm{Hf}$ ratios ranging $028124-0.28133$ with $\varepsilon \mathrm{Hf}_{(\mathrm{T})}$ values 535 of +1.7 to +6.2 . The depleted mantle $\left(\mathrm{T}_{\mathrm{DM}}\right)$ model ages range from $2955-2685 \mathrm{Ma}\left(\mathrm{T}_{\mathrm{DM} 2}\right)$.

\section{$536 \quad 5.2$ Eastern block}

\section{$537 \quad$ 5.2.1 Transitional TTGs and diatexites}

538 Sample KO-8 $\left(13^{\circ} 43^{\prime} 21^{\prime \prime} N\right.$; 78 $\left.20^{\prime} 06^{\prime \prime} E\right)$-Banded tonalitic gneiss

539 Sample KO-8 is a dark grey banded tonalitic gneiss collected north of Horsley Hill (Fig.2).

540 The zircon CL images display cores with concentric growth zoning, typical of magmatic 541 growth in a magma, surrounded by recrystallized rims. Overgrowths of dark-CL zircon with 542 euhedral to subhedral forms are commonly present. Most of the analyzed sites contain 543 variable U contents (230-903 ppm, with a few outliers having 16-18 ppm; \#9-1 and \#9-2) and 544 low Th contents (1-269 ppm). The Th/U ratios range from 0.06 to 0.41 . The results define a 545 discordia, with the upper intercept ${ }^{207} \mathrm{~Pb} /{ }^{206} \mathrm{~Pb}$ age of $2564 \pm 13 \mathrm{Ma}$ (Fig.8.3a).

546 In-situ Hf isotope data for the zircon reveal ${ }^{176} \mathrm{Hf} /{ }^{177} \mathrm{Hf}$ ratios ranging from $0.28110-0.28120$ 547 with $\varepsilon \mathrm{Hf}_{(\mathrm{T})}$ values of +0.8 to -3.2 . The depleted mantle $\left(\mathrm{T}_{\mathrm{DM}}\right)$ model ages range from 2925$5482836\left(\mathrm{~T}_{\mathrm{DM} 1}\right)$ and $3240-3015 \mathrm{Ma}\left(\mathrm{T}_{\mathrm{DM} 2}\right)$.

549 Sample KO-7 (1339'34"N; 78²5'16"E)-Diatexitic gneiss

550 This sample is a light pinkish-grey diatexitic gneiss collected at the second turning on the 551 way to the top of Horsley Hill (Fig. 2). The CL images of the analysed zircons show dark 552 luminescence with concentric prismatic to pyramidal zones typical of magmatic growth. 553 They record low to moderate $\mathrm{U}(82-733 \mathrm{ppm})$ and $\mathrm{Th}(60-850 \mathrm{ppm})$ contents, with $\mathrm{Th} / \mathrm{U}$ 554 ratios ranging from 0.31 to 2.19 . Nine grains define a discordia with an upper intercept ${ }^{207} \mathrm{~Pb} /{ }^{206} \mathrm{~Pb}$ age of $2586 \pm 33 \mathrm{Ma}(\mathrm{MSWD}=0.70$ ), (Fig. 8.3b). This age corresponds to time of 556 magmatic crystallization. 
557 Hf isotope data reveals ${ }^{176} \mathrm{Hf} /{ }^{177} \mathrm{Hf}_{(\mathrm{T})}$ ratios ranging from 0.28127 to 0.28132 , with $\varepsilon \mathrm{Hf}_{(\mathrm{T})}$ 558 values from +3.3 to +7.4 . The depleted mantle $\left(\mathrm{T}_{\mathrm{DM}}\right)$ model ages range from $2887-2614 \mathrm{Ma}$ $559\left(\mathrm{~T}_{\mathrm{DM} 2}\right)$.

$560 \quad$ 5.2.2 Calc-alkaline granitoids

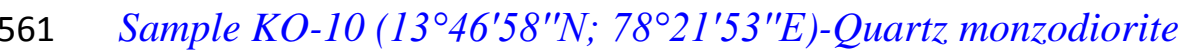

562 Dark grey quartz monzodiorite was collected in the north-eastern outskirts of Devalacheruvu 563 (Fig.2). Zircons reveal elongated prismatic morphology with partially developed terminal 564 pyramids. The CL images display concentric oscillatory zoning of magmatic origin. The 565

\section{Whole-rock geochemistry}

\subsection{Major and trace elements}

Analytical methods for major and trace elements are presented in the Appendix. The major and trace element data are presented in Supplementary table 3. 
A total of 73 samples representing banded dark grey gneisses (transitional TTGs), granitoids (intrusive and anatectic granites), MMEs/synplutonic dykes from the studied corridor of both the Central and Eastern blocks were analysed for major and trace elements. Published data for ca. 3300-3000 Ma migmatitic gneisses (Moyen et al., 2003a; Jayananda et al., 2000, 2018) are used for comparison. The migmatitic TTGs, transitional TTGs, sanukitoids and anatectic granites exhibit distinct major and trace element characteristics.

The ca. 3360-3000 Ma old migmatitic TTGs are mainly restricted to the Central block and are characterized by high $\mathrm{SiO}_{2}$ (70-76 wt\%) compared to the ca. 2670-2600 Ma dark grey banded gneisses $\left(\mathrm{SiO}_{2}=63-71 \mathrm{wt} \%\right)$ and ca. $2570-2520 \mathrm{Ma}$ granitoids $\left(\mathrm{SiO}_{2}=63-69 \mathrm{wt} \%\right)$. In this study, our use of elemental data from the migmatitic TTGs is restricted to discuss secular changes in petrogenetic and geodynamic processes through time. The transitional TTGs of the Central block contain lower $\mathrm{SiO}_{2}$ (66 to $71 \mathrm{wt} \%$ ) and higher $\mathrm{MgO}(0.97-2.49 \mathrm{wt} \%)$ than the transitional TTGs of the Eastern block, which record $\mathrm{SiO}_{2}$ of $63-71$ wt $\%$ and $\mathrm{MgO}$ of 0.45-2.32 wt\%. Further elemental characteristics of the ca. 2570-2520 Ma granitoid plutons of the Eastern Dharwar Craton with sanukitoid affinity have been documented in several studies (Balakrishnan and Rajamani, 1987; Jayananda et al., 1995, 2000, 2018; Moyen et al., 2003a; Sarvothaman, 2001; Dey et al. 2012, 2014, 2016). Consequently, we describe the granitoids with lower $\mathrm{SiO}_{2}$, higher $\mathrm{MgO}$ and incompatible elements from the studied corridor as sanukitoids.

On the Ab-An-Or (Fig. 9a) triangular diagram (O’Conner, 1965 with fields by Barker, 1979) the transitional TTGs plot in the tonalite field, with a few samples extending into the granodiorite domain, whereas the $>3000$ Ma TTGs plot mainly in the trondhjemite field (shown as shaded area in Fig. 9a). The sanukitoids plot in the granodiorite field and extend into the quartz monzonite field, whereas the anatectic granites plot mainly in the granite field and the synplutonic dykes plot in the tonalite-granodiorite and quartz monzonite fields (Fig. 9a). On the K-Na-Ca triangular plot (Fig. 9b), the transitional TTGs define a trend transitional between trondhjemite (TTGs) and calc-alkaline (granitoids), whilst sanukitoids, anatectic granites and syn-plutonic mafic dykes follow the calc-alkaline differentiation trend. The $\mathrm{Al}_{2} \mathrm{O}_{3} /\left(\mathrm{CaO}+\mathrm{Na}_{2} \mathrm{O}+\mathrm{K}_{2} \mathrm{O}\right)$ mol versus $\mathrm{K}_{2} \mathrm{O} / \mathrm{Na}_{2} \mathrm{O}$ mol plot (Fig. 9c), as well as on the $\mathrm{Al}_{2} \mathrm{O}_{3} /\left(\mathrm{FeO}_{\mathrm{t}}+\mathrm{MgO}\right)$ versus $\mathrm{CaO} /\left(\mathrm{Na}_{2} \mathrm{O}+\mathrm{K}_{2} \mathrm{O}\right)$ plot (Fig. $\left.9 \mathrm{~d}\right)$, shows the transitional TTGs extend from the TTG into the sanukitoid field, whereas the younger sanukitoid and anatectic granites plot in the biotite-granite field. On Harker binary diagrams (Fig. 10), the transitional TTGs, sanukitoids, and anatectic granites define moderate to strong linear trends. The fragmented synplutonic mafic dykes form two groups with one group (hybrid facies?) defining a trend 
together with the sanukitoids, whereas others form a cluster outside the main trend (Fig. 10). All the studied rocks collectively define linear trends on Harker major element binary plots, implying a genetic link.

Among the trace elements, $\mathrm{Sr}, \mathrm{Ni}, \mathrm{Cr}$, and $\mathrm{V}$ of the individual groups (transitional TTGs, sanukitoids, anatectic granite) define moderate to strong negative trends against $\mathrm{SiO}_{2}$, except for $\mathrm{Rb}$ that shows a positive trend. The synplutonic mafic dykes form clusters with a few samples (hybrid facies?) defining a trend together with the sanukitoids. Zirconium displays a very weak negative trend, whereas $\mathrm{Ba}, \mathrm{Nb}$ and $\mathrm{Y}$ show a large spread.

Leedy chondrite (Masuda et al., 1973) data were divided by 1.2 with values for Pr, Tb, Ho and Tm interpolated after Taylor and Gordon (1977). The studied rocks from the Central and Eastern blocks show large variations in total rare earth elements (REE) contents and display distinct chondrite normalized REE patterns. The >3000 Ma old migmatitic TTGs in the Central block are characterized by low to moderate total REE (9.2-163.0 ppm) with moderate to highly fractionated REE patterns without any significant Eu anomalies (cf. Jayananda et al., 2018). On the primitive mantle (Sun and McDonough, 1989) normalized multi-element diagram these rocks display weak negative or no Ba-Sr anomalies, but have strong negative $\mathrm{Nb}-\mathrm{Ta}-\mathrm{Ti}$ anomalies that suggest retention of minor plagioclase and also significant titanite and/or ilmenite in the source residue (Jayananda et al., 2018). The transitional TTGs of the Central block display moderate to high total REE (95-325 ppm) with moderate to highly fractionated REE patterns $\left[(\mathrm{La} / \mathrm{Yb})_{\mathrm{N}}=14.26-57.68\right]$ and weak negative to positive (or no) $\mathrm{Eu}$ anomalies $\left(\mathrm{Eu} / \mathrm{Eu}^{*}=0.86-1.10\right.$, Fig. 11a). On the primitive mantle normalized multi-element spider diagram the transitional TTGs exhibit positive $\mathrm{Sr}$ anomalies (except one sample with a negative anomaly) but without $\mathrm{Ba}$ anomalies and with strong negative $\mathrm{Nb}$-Ta-Ti anomalies, implying clinopyroxene, hornblende, titanite and/or ilmenite, with or without garnet and plagioclase, in the source residue (Fig. 11b).

Data obtained in this study, together with published data (Jayananda et al., 1995, 2000) for sanukitoids from the Central block, reveal high to very high total REE (200-1076 ppm), except for a few samples that show slightly lower total REE $(<200 \mathrm{ppm})$ concentrations. They define poorly to highly fractionated REE patterns, with $(\mathrm{La} / \mathrm{Yb})_{\mathrm{N}}$ values ranging from 7.51- 45.22 (Fig. 11c) and with minor negative or no Eu anomalies (Eu/Eu* $=0.44-1.08)$. Further, on the primitive mantle normalized multi-element diagram (Fig. 11d) they show strong negative $\mathrm{Nb}$ - $\mathrm{Ta}-\mathrm{Ti}$ anomalies accompanied by positive $\mathrm{Sr}$, but mostly without $\mathrm{Ba}$ 
anomalies (only one sample shows a negative anomaly) and with weakly negative or no $\mathrm{Y}$ anomalies, suggesting residual clinopyroxene, titanite and/or ilmenite, with variable garnet, but without any significant plagioclase in the source residue. The anatectic granites record low to high total REE (43-384 ppm; this study and Jayananda et al., 2000) and show moderate to highly fractionated $\left[(\mathrm{La} / \mathrm{Yb})_{\mathrm{N}}=7.4-46.5\right]$ patterns with strong negative Eu anomalies $\left(\mathrm{Eu} / \mathrm{Eu}^{*}=0.43-0.52\right.$, Fig. 11e $)$, together with negative $\mathrm{Ba}-\mathrm{Sr}$ and $\mathrm{Nb}-\mathrm{Ta}-\mathrm{Ti}$ anomalies (Fig. 11f), indicating major residual plagioclase, biotite, titanite and/or ilmenite, but with minor or no residual garnet in the source. The synplutonic mafic dykes in the Central block form two distinct patterns of REE. Group I has slightly higher $\mathrm{SiO}_{2}(50-52 \mathrm{wt} \%)$ and is characterized by low to moderate total REE (32-171 ppm) and flat REE patterns with $(\mathrm{La} / \mathrm{Yb})_{\mathrm{N}}$ ratios ranging from 1.23 -2.13 (Fig. 11g). Group 2 has lower $\mathrm{SiO}_{2}(48-59 \mathrm{wt} \%)$ and high total REE (108-775 ppm) contents, with moderate to strongly fractionated $\left[(\mathrm{La} / \mathrm{Yb})_{\mathrm{N}}\right.$ $=11.0-37.78]$ patterns (Fig. 11i). Both groups of synplutonic mafic dykes record either negative or positive $\mathrm{Ba}-\mathrm{Sr}$ anomalies with strongly negative $\mathrm{Nb}-\mathrm{Ta}-\mathrm{Ti}$ anomalies, suggesting retention of olivine, clinopyroxene, phlogopite, titanite and /or ilmenite in the mantle source (Fig. 11h \& j).

In the Eastern block, the transitional TTGs exhibit moderate to high total REEs (72-393 ppm) and moderate to strongly fractionated REE patterns $\left.\left[(\mathrm{La} / \mathrm{Yb})_{\mathrm{N}}=10.76-50.45\right)\right]$ without any significant $\mathrm{Eu}$ anomalies $\left(\mathrm{Eu} / \mathrm{Eu}^{*}=0.84-1.02\right.$, Fig. 12a). On the primitive mantle normalized spider diagram (Fig. 12b), Sr shows both positive and negative anomalies, with strong negative $\mathrm{Ba}-\mathrm{Nb}$-Ta-Ti anomalies and weakly negative or no $\mathrm{Y}$ anomalies, suggesting variable residual plagioclase, clinopyroxene, hornblende, garnet, titanite and/or ilmenite in the source residue.

The sanukitoids have low to moderate total REE (68-314 ppm) contents but highly fractionated $\left[(\mathrm{La} / \mathrm{Yb})_{\mathrm{N}}=20.87-60.61\right]$ patterns without any significant Eu anomalies $\left(\mathrm{Eu} / \mathrm{Eu}^{*}=0.78-1.09\right.$, Fig. 12c). They display positive Ba-Sr anomalies, but strong negative $\mathrm{Nb}-\mathrm{Ta}-\mathrm{Ti}$ anomalies and weak positive $\mathrm{Y}$ anomalies (Fig. 12d), suggesting residual clinopyroxene, hornblende, titanite and/or ilmenite without any significant residual plagioclase or garnet. The anatectic granites have low to high total REEs (26-395 ppm) and show moderate to strongly fractionated REE patterns $\left[(\mathrm{La} / \mathrm{Yb})_{\mathrm{N}}=14.65-66.45\right]$, with negative Eu anomalies $\mathrm{Eu}\left(\mathrm{Eu} / \mathrm{Eu}^{*}=0.38-0.83\right.$, Fig. 12e $)$, implying residual plagioclase in the source. The anatectic granites display negative $\mathrm{Ba}-\mathrm{Sr}, \mathrm{Nb}-$ Ta-Ti anomalies on the primitive mantle normalized multi-element spider diagram (Fig. 12f), 
suggesting residual plagioclase, clinopyroxene, biotite, titanite and/or ilmenite. The synplutonic mafic dykes display high total REEs (104-204 ppm) with moderate to highly fractionated REE patterns $\left[(\mathrm{La} / \mathrm{Yb})_{\mathrm{N}}=6.27-25.39\right]$ without any significant Eu anomalies (Fig. 12g). The observed positive $\mathrm{Sr}$ and $\mathrm{Ba}$ anomalies are coupled with negative $\mathrm{Nb}-\mathrm{Ta}-\mathrm{Ti}$ anomalies (Fig. 12h).

\subsection{Zircon in-situ Hf isotopes and whole-rock Nd isotopes}

Fourteen samples whose zircons were analysed for $\mathrm{Lu}-\mathrm{Hf}$ isotope compositions reveal significant variability in $\mathrm{Hf}$ isotope compositions, with initial ${ }^{176} \mathrm{Hf} /{ }^{177} \mathrm{Hf}_{(\mathrm{T})}$ ratios $(0.28066$ to 0.28135$)$ and $\varepsilon H f_{(\mathrm{T})}$ values of +7.8 to -10.7 (Supplementary table 2). The migmatitic gneisses, together with published data (Bidyananda et al., 2016; Dey et al., 2016), have variable initial ${ }^{176} \mathrm{Hf} /{ }^{177} \mathrm{Hf}$ isotope compositions ( 0.281236 to 0.280680$)$ with positive $\varepsilon \mathrm{Hf}_{(\mathrm{T})}=+3$ to +6 , indicating slight $\mathrm{Hf}$ isotope heterogeneity on the grain scale. The transitional TTGs have initial ${ }^{176} \mathrm{Hf} /{ }^{177} \mathrm{Hf}$ ratios ranging from 0.28110 to 0.28132 with $\varepsilon \mathrm{Hf}_{(\mathrm{T})}=+7.8$ to -3.2 , indicating significant $\mathrm{Hf}$ isotope heterogeneity and composite sources involving depleted to chondritic mantle reservoirs with minor crustal contamination, particularly in the western part of the corridor. Sanukitoids show significant variation in initial ${ }^{176} \mathrm{Hf} /{ }^{177} \mathrm{Hf}$ compositions $(0.28101-0.28135)$, with $\varepsilon \mathrm{Hf}_{(\mathrm{T})}=+6.9$ to -6.1 , which could be related to $\mathrm{Hf}$ isotope heterogeneity involving depleted to enriched mantle with ancient crustal contamination. The anatectic granite from the Central block shows evolved initial ${ }^{176} \mathrm{Hf} /{ }^{177} \mathrm{Hf}_{(\mathrm{T})}$ composition $(0.28066)$, with $\varepsilon \mathrm{Hf}_{(\mathrm{T})}=-2.0$ to -10.7 , indicating reworking of ancient crust. The initial ${ }^{176} \mathrm{Hf} /{ }^{177} \mathrm{Hf}_{(\mathrm{T})}$ versus zircon age plot (Fig. 13a) and $\varepsilon \mathrm{Hf}_{(\mathrm{T})}$ versus zircon ages (Fig. 13b) reveal a chondritic to depleted mantle source for the magmatic precursors of the ca. 3360-3000 Ma migmatitic gneisses, with traces of significant ancient crustal input (in the Central block), depleted to chondritic mantle for the transitional TTGs, a chondritic to enriched mantle source, with or without crustal contamination, for the sanukitoids and ancient to short lived crust for the anatectic granites.

Whole rock Nd isotope data are presented in Supplementary table 4. The studied gneisses and granitoids display significant variation in $\mathrm{Nd}$ isotope compositions.

In the Central block, the 3271 Ma migmatitic basement gneisses record $\varepsilon \mathrm{Nd}_{(\mathrm{T}=3271 \mathrm{Ma})}$ values of +1.97 to -0.5 , with $\mathrm{Nd}_{\mathrm{TDM}}$ ages of $3400-3335$, which are close to the U-Pb zircon age, suggesting derivation of the magmatic precursors from short-lived mafic crust. The ca. 2670-2600 Ma transitional TTG have $\varepsilon \mathrm{Nd}_{(\mathrm{T})}$ ranging from +2.75 to +1.71 , with corresponding $\mathrm{Nd}_{\mathrm{TDM}}$ ages of 2919-2735 Ma, which are slightly older than the U-Pb zircon ages. These values indicate the 
origin of the rocks either from short-lived mafic crust or from composite sources involving the mantle as well as short-lived mafic crust. The four samples of sanukitoids show $\varepsilon \mathrm{Nd}_{(\mathrm{T}=2545 \mathrm{Ma})}$ values ranging from +1.99 to -1.26 , with $\mathrm{Nd}_{\mathrm{TDM}}$ ages of 2700-3000 Ma. The fragmented synplutonic mafic dyke has a slightly negative $\varepsilon \mathrm{Nd}_{(\mathrm{T}=2535 \mathrm{Ma})}$ value of -0.82 with an older $\mathrm{Nd}_{\mathrm{TDM}}$ age of $2920 \mathrm{Ma}$ compared to the zircon age of $2535 \mathrm{Ma}$. The $\varepsilon \mathrm{Nd}$ values of the sanukitoids and associated synplutonic dykes imply their derivation from mantle reservoirs contaminated by preexisting crust. The anatectic pink granite, together with published data, has high negative $\varepsilon \mathrm{Nd}_{(\mathrm{T}=2535)}$ values of -5.44 to 0.0 , with corresponding model ages of 3400-2700 Ma (Moyen, 2000; Dey et al., 2014; Jayananda et al., 2000, 2018), suggesting its origin through reworking of ancient as well as newly-formed juvenile felsic crust. Five samples of transitional TTG in the Eastern block record positive $\varepsilon \mathrm{Nd}_{(\mathrm{T})}$ values ranging from +2.6 to +0.53 , with $\mathrm{Nd}_{\mathrm{TDM}}$ ages ranging from 2706-2798 Ma, which are slightly older than the zircon crystallization ages. These values suggest a short-lived juvenile source or depleted to chondritic mantle derived melts contaminated by lower crust. The sanukitoids record positive $\varepsilon \mathrm{Nd}_{(\mathrm{T})}$ ranging from +1.21 to +0.93 with corresponding $\mathrm{Nd}_{\mathrm{TDM}}$ ages of 2878-2798 Ma, indicating their derivation from a juvenile source without much ancient crustal contamination. In summary, whole-rock Nd isotope data indicate major mantle input, with minor ancient crustal signatures during Neoarchean accretion of the Central block, whereas such ancient crustal signatures are not evident in the Eastern block (Fig. $13 \mathrm{c})$.

\section{Discussion}

\subsection{Effects of secondary processes on elemental compositions}

The studied corridor was affected by shear deformation, fluid flow and amphibolite to granulite facies metamorphism (Chardon et al., 2008, 2011; Jayananda et al., 2006, 2013a). Therefore, it is necessary to evaluate the effects of fluid flow and metamorphism on element mobility prior to using the elemental data to constrain petrogenetic processes, including the composition of potential source regions as well as the geodynamic context of magma generation.

The modification of elemental composition of some samples by secondary processes including fluid induced hydrothermal alteration and/or medium- to high-grade metamorphism, has resulted in significant variation in $\mathrm{K}_{2} \mathrm{O}$ and $\mathrm{Na}_{2} \mathrm{O}$ contents, the spread of values for the large-ion lithophile elements (LILE), including $\mathrm{Rb}, \mathrm{Ba}$ and to some extent $\mathrm{Sr}$, on the Harker diagrams, and variations revealed on the multi-element spider diagrams. However, relatively immobile 
elements like REE, $\mathrm{Nb}, \mathrm{Ta}, \mathrm{Y}, \mathrm{Zr}$ and $\mathrm{Hf}$ display smooth patterns on primitive mantle normalized multi-element diagrams, therefore these elements can be used as robust tracers to constrain potential sources of the different gneisses and granitoids of the studied corridor. Further, Polat and Hoffmann (2003) proposed that rocks with high loss of ignition (LOI >6.0 wt $\%$ ) and large $\mathrm{Ce}$ anomalies (positive or negative) may be significantly affected by secondary alteration processes. However, most of the analysed samples in the present study exhibit much lower LOI $(<1.0 \mathrm{wt} \%)$ and do not show any Ce anomalies. This precludes significant alteration of elemental composition of the analysed samples by post-magmatic secondary processes. Further, Jayananda et al $(2000,2015,2018)$ addressed the issue of the effect of secondary processes on the elemental and isotopic compositions and concluded that only LILE (Cs, Rb, K, $\mathrm{Ba}$ and $\mathrm{Sr})$ are disturbed to some extent, but that REE and high field strength elements $(\mathrm{Nb}, \mathrm{Ta}$, $\mathrm{Ti}, \mathrm{Zr}, \mathrm{Hf}, \mathrm{Sc}, \mathrm{Y}$ ) were not affected. Consequently, primary geochemical signatures of most of the elements have not been disturbed and these elements can be used to discuss petrogenesis and geodynamic context of magma genesis.

\subsection{Petrogenesis and sources}

762 The zircon $\mathrm{U}-\mathrm{Pb}$ data presented in this study, together with published data, show that migmatitic 763 TTGs, transitional TTGs, sanukitoids, and synplutonic mafic dykes and anatectic granites 764 correspond to crust building events at ca. 3360-3000 Ma, 2670-2600 Ma, 2573-2526 Ma and $7652530 \mathrm{Ma}$, respectively.

\subsubsection{Ca. 3360-3000 Ma Migmatitic TTGs}

The origin of TTGs is a topic of much debate, with diverse models proposed in the past two decades (Smithies et al., 2000; Rapp et al., 2003; Martin et al., 2005, 2014; Moyen, 2011; Polat, 2012; Hoffmann et al., 2011; Jayananda et al., 2015, 2018). The origin of Archean TTGs from different cratons has been explained by hydrous melting of down-going oceanic crust (Martin, 1986; Feng and Kerrich, 1992; Foley et al., 2002), melting of subducted oceanic plateaus (Martin et al., 2014), or melting of thickened oceanic arc crust (Hoffmann et al., 2011; Polat, 2012; Jayananda et al., 2015, 2018). It is generally accepted that TTGs are generated by hydrous melting of mafic rocks at different depths (Moyen, 2011). However, the composition of the mafic crust and tectonic context of TTG magma genesis remains strongly debated (Johnson et al., 2019). The $>3000$ Ma old migmatitic TTGs in the Central block of the Dharwar Craton are characterized by high $\mathrm{SiO}_{2}(>70 \mathrm{wt} \%$, except for one sample containing $66.0 \mathrm{wt} \%)$, high

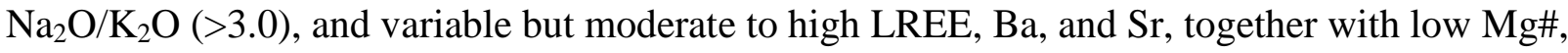


$\mathrm{Ni}$ and $\mathrm{Cr}$. These characteristics preclude melting of a down-going oceanic slab in a subduction zone as the source, because "oceanic crust formed at a spreading centre is strongly depleted and cannot account for the high content of incompatible elements" (Smithies et al., 2000; Hoffmann et al., 2011; Jayananda et al., 2015). Alternatively, two-stage melting involving melting of subducted oceanic crust to generate new oceanic arc crust, followed by hydrous melting of the subsequently thickened arc crust at different depths, may be a possibility (Hoffmann et al., 2011; Polat, 2012). Partial melting of thickened oceanic arc crust at different depths with variable hornblende, clinopyroxene, plagioclase, garnet, titanite/ilmenite in the residue could account for the observed high REE contents, low Mg\# $(<0.30)$, moderate to high $(\mathrm{La} / \mathrm{Yb})_{\mathrm{N}}$ and $\mathrm{Sr} / \mathrm{Y}$, variable Ba-Sr and negative Nb-Ti anomalies on spider diagrams (Jayananda et al., 2018). Thus, high incompatible element contents, together with highly fractionated REE, negative $\mathrm{Nb}-\mathrm{Ta}-\mathrm{Ti}$ anomalies of the $>3000$ Ma migmatitic TTGs in the Central block probably originated by melting of short-lived thickened mafic oceanic arc crust at different depths. This agrees with the $\mathrm{Nd}$ isotope data that record a $\mathrm{Nd}_{\mathrm{TDM}}$ age of 3400-3365 Ma, whereas U-Pb zircon defines a slightly younger age of $3360-3271 \mathrm{Ma}$, with $\varepsilon \mathrm{Nd}_{(\mathrm{T})}$ values of +1.97 to -0.5 , suggesting a twostage melting process for the origin of the TTGs.

\subsubsection{Ca. 2670-2600 Ma Transitional TTGs}

The lower $\mathrm{SiO}_{2}(68.0 \mathrm{wt} \%)$, higher $\mathrm{MgO}(1.3 \mathrm{wt} \%), \mathrm{CaO}(3.06 \mathrm{wt} \%)$ and $\mathrm{K}_{2} \mathrm{O}(2.40 \mathrm{wt} \%)$, and lower $\mathrm{Na}_{2} \mathrm{O} / \mathrm{K}_{2} \mathrm{O}$ ratios (1.92) but higher $\mathrm{Mg \#} \mathrm{(>0.39)}$ of the transitional TTGs compared to the ca. 3360-3000 Ma migmatitic TTGs from the Central block [average $\mathrm{SiO}_{2}(72.42 \mathrm{wt} \%), \mathrm{MgO}$ ( $0.58 \mathrm{wt} \%), \mathrm{CaO}(2.15 \mathrm{wt} \%), \mathrm{K}_{2} \mathrm{O}(1.68 \mathrm{wt} \%)$, reveal their transitional character between TTGs and calc-alkaline granitoids of sanukitoid affinity, as do their higher $\mathrm{Na}_{2} \mathrm{O} / \mathrm{K}_{2} \mathrm{O}$ ratios $(>3.0)$, but lower Mg\# (<0.30)], together with their abundant biotite, hornblende and local clinopyroxene (Jayananda et al., 2018). The origin of Neoarchean transitional TTGs has been explained by melting of mafic lower crust (Champion and Smithies, 2003b; Jayananda et al., 2006; Dey et al., 2016) or by melting of composite sources involving both arc crust and sub-arc mantle (Jayananda et al., 2018). Moderate to strong fractionation trends of $\mathrm{Fe}_{2} \mathrm{O}_{3}, \mathrm{MgO}, \mathrm{MnO}, \mathrm{CaO}$, $\mathrm{TiO}_{2}$, and $\mathrm{P}_{2} \mathrm{O}_{5}$ versus $\mathrm{SiO}_{2}$ on Harker diagrams (see Fig. 10) indicate removal of clinopyroxene, hornblende, minor plagioclase, and ilmenite/titanite as fractionating phases or their retention in the source residue.

Hydrous melting of a down-going oceanic slab in a subduction zone can be considered for the origin of transitional TTGs. However, their high content of incompatible elements $(\mathrm{K}, \mathrm{Rb}, \mathrm{Ba}$, 
$\mathrm{Sr}, \mathrm{Zr}, \mathrm{Th}, \mathrm{U})$ precludes slab melting in a subduction zone, as oceanic crust generated at spreading centres is highly depleted in incompatible elements. Melting of such depleted source regions generates melts with much lower incompatible element contents (Smithies et al., 2009; Nagel et al., 2012). An alternate possibility is a two-stage melting process involving melting of hydrated oceanic crust in a subduction zone producing oceanic arc crust, followed by melting of such thickened arc crust to generate magmatic precursors of the transitional TTGs. However, recent petrological and experimental data show that melting of thickened mafic arc crust at different depths generates TTG magmas (Hoffmann et al., 2011; Nagel et al., 2012; Polat, 2012) with high $\mathrm{SiO}_{2}$, and low $\mathrm{K}_{2} \mathrm{O}, \mathrm{Rb}, \mathrm{Ba}, \mathrm{Sr}, \mathrm{MgO}$, Ni and $\mathrm{Cr}$ contents. On the other hand, transitional TTGs contain low $\mathrm{SiO}_{2}$ but conversely high $\mathrm{MgO}, \mathrm{K}_{2} \mathrm{O}, \mathrm{Rb}, \mathrm{Ba}, \mathrm{Sr}, \mathrm{Ni}$, and $\mathrm{Cr}$ contents, coupled with abundant hornblende \pm clinopyroxene, calcic plagioclase, and K-feldspar, which cannot be explained by melting of thickened arc crust alone. This feature is reflected on the $3 * \mathrm{CaO}-\mathrm{Al}_{2} \mathrm{O}_{3} / \mathrm{FeO}_{\mathrm{t}}+\mathrm{MgO}-5 *\left(\mathrm{~K}_{2} \mathrm{O} / \mathrm{Na}_{2} \mathrm{O}\right)$ triangular plot (Laurent et al., 2014), wherein the transitional TTGs plot both in the low-K as well as the high-K mafic source fields (Fig. 14a), implying the involvement of both thickened arc crust as well as an enriched source, possibly from the mantle. Involvement of both mafic arc crust as well as a mantle source (depleted to chondritic) is also reflected in the $\mathrm{Sr}+\mathrm{Ba}$ versus $\mathrm{FeOt}+\mathrm{MgO}$ binary plot (Laurent et al 2014) where the transitional TTGs plot in the crustal source field and extend into the field of enriched mantle (Fig. 14b). Whole rock $\mathrm{Nd}$ isotopic data $\left(\varepsilon_{\mathrm{Nd}}=0.52\right.$ to 4.23$)$ suggest composite sources involving both short-lived mafic arc crust as well as a mantle (chondritic to depleted) source. This is also in agreement with in-situ $\mathrm{Hf}$ isotope data of zircons $\left[\varepsilon \mathrm{Hf}_{(\mathrm{T})}=-0.67\right.$ to 5.61]. The strongly fractionated REE patterns (14.2-57.6, Fig. 11a) together with the $\mathrm{Sr} / \mathrm{Y}$ versus $\mathrm{Y}$ (Fig. 15a) and (La/Yb) $)_{\mathrm{N}}$ versus $\mathrm{Yb}$ (Fig. 15b) plots suggest variable amounts of clinopyroxene, hornblende and garnet (0-30\%) in the source residue. Furthermore, the strong negative $\mathrm{Nb}$ and Ti anomalies in the multi-element spider diagrams indicate retention of ilmenite and/or titanite in the source residue, whereas positive $\mathrm{Sr}$ anomalies, or the absence of anomalies, imply minor or no significant residual plagioclase. Although the transitional TTGs of the Central and Eastern blocks share broadly similar elemental characteristics, they do show significant variation in some elements. The higher contents of $\mathrm{Ba}-\mathrm{Sr}, \mathrm{MgO}, \mathrm{Ni}, \mathrm{Cr}$ and $\mathrm{V}$ of rocks from the Central block imply a dominantly mantle input (chondritic to slightly depleted), whilst slightly lower contents in the Eastern block suggest lesser mantle input and dominantly arc crust involvement.

It is important to constrain the melting conditions and mineralogy of the source residue. The strong negative $\mathrm{Nb}$, Ta and $\mathrm{Ti}$ anomalies on the multi-element spider diagrams (see Figs. 11, 12) 
suggest residual titanite and/or ilmenite. The $\mathrm{Nb} / \mathrm{Ta}, \mathrm{Zr} / \mathrm{Hf}$, and $\mathrm{Zr} / \mathrm{Sm}$ ratios can be used as powerful tracers to characterize source compositions and residual mineralogy, as these elemental pairs have different partition coefficients for residual phases like amphibole, clinopyroxene, titanite, ilmenite and rutile (Foley et al., 2002; Rapp et al., 2003; Xiong et al., 2007; Zhou et al., 2014). Amphibole has a major control on $\mathrm{Nb} / \mathrm{Ta}, \mathrm{Zr} / \mathrm{Sm}$ and $\mathrm{Zr} / \mathrm{Hf}$ ratios, as well as heavy ( $\mathrm{Yb}$ ) to middle (Gd, Dy) REE. Consequently, melts generated with hornblende in the source residue would be expected to have low $\mathrm{Nb} / \mathrm{Ta}, \mathrm{Gd} / \mathrm{Yb}$, and $\mathrm{Dy} / \mathrm{Yb}$, but high $\mathrm{Zr} / \mathrm{Sm}$ ratios (Zhou et al., 2014). On the contrary, garnet retained in the source residue increases the $\mathrm{Sr} / \mathrm{Y}, \mathrm{La} / \mathrm{Yb}$ and $\mathrm{Zr} / \mathrm{Sm}$ ratios (Davidson et al., 2007). The $\mathrm{Nb} / \mathrm{Ta}$ versus $\mathrm{Zr} / \mathrm{Sm}$ plot suggests dominant amphibole and clinopyroxene, with variable amounts of garnet and ilmenite, in the source residue (Fig. 16). In addition, melts with residual garnet are generally expected to show a negative correlation of $\mathrm{Al}_{2} \mathrm{O}_{3}$ with $\mathrm{SiO}_{2}$, but the very weak correlation of $\mathrm{Al}_{2} \mathrm{O}_{3}$ with $\mathrm{SiO}_{2}$ (see Fig. 10) precludes major residual garnet in the source, which is also in agreement with the absence of a strong positive correlation between $\mathrm{Sr} / \mathrm{Y}$ versus $(\mathrm{La} / \mathrm{Yb})_{\mathrm{N}}$ (Figure presente $)$ In contrast, the plots of $(\mathrm{La} / \mathrm{Yb})_{\mathrm{N}}$ versus $(\mathrm{Yb})_{\mathrm{N}}$ and $\mathrm{Sr} / \mathrm{Y}$ versus $\mathrm{Y}$ suggest variable $(0-30 \%)$ residual garnet in the source (see Figs. 15a,b). The low Dy/Yb (1.99-3.22), Gd/Yb (2.22 -5.38), and Nb/Ta (5.24-14.03) ratios, together with variable $\mathrm{Zr} / \mathrm{Sm}$ values (11.88-66.40), indicate amphibole and/or clinopyroxene together with variable garnet in the melt residue (Jenner et al., 1994; Klemme et al., 2002). This is in agreement with the observed low to high $\mathrm{Cr} / \mathrm{V}$ values (0.49-2.04), suggesting major amphibole and/or clinopyroxene, plus variable (0-30\%) garnet in the residue. The absence of significant Eu anomalies with only minor negative or rare positive $\mathrm{Eu} / \mathrm{Eu} *$ values, implies magma generation close to or below the plagioclase stability field (Fig. 11a, c).

In summary, the elemental and Hf-Nd isotope data indicate that the magmatic protoliths of the transitional TTGs were derived by melting of composite sources involving juvenile thickened mafic arc crust and underlying sub-arc mantle, with clinopyroxene, hornblende, garnet (0 -30\%), minor or no plagioclase, and titanite/ilmenite in the source residue.

\subsubsection{Ca. 2570-2535 Ma Sanukitoids}

Sanukitoids are intermediate to felsic magmatic rocks enriched in both incompatible (LILE, HFSE, REE) and compatible ( $\mathrm{Mg}, \mathrm{Ni}, \mathrm{Cr}$ ) elements which post-date the accretion of TTGs. Numerous studies have investigated sanukitoids from different cratons and have shown geochemical and isotope signatures corresponding to major juvenile additions, with or without minor ancient crustal input (for reviews see Shirey and Hanson, 1984; Jayananda et al., 1995, 
2000, 2018; Smithies and Champion, 2000; Moyen et al., 2003a; Martin et al., 2005, 2010;

Lobach-Zhuchenko et al., 2008; Halla et al., 2005; Wang et al., 2009; Heilimo et al., 2010; Laurent et al., 2014).

The data presented here, together with published data (Jayananda et al., 1995, 2000; Moyen, 2000; Moyen et al., 2003; Dey et al., 2014, 2016) from the Central and Eastern Dharwar Craton, reveal a wide range of compositions $\left(\mathrm{SiO}_{2}, 50-71 \mathrm{wt} \%\right)$, suggesting that their parental magmas evolved through differentiation processes. The negative trends of $\mathrm{MgO}, \mathrm{Fe}_{2} \mathrm{O}_{3}, \mathrm{MnO}, \mathrm{CaO}, \mathrm{TiO}_{2}$ and $\mathrm{P}_{2} \mathrm{O}_{5}$ against $\mathrm{SiO}_{2}$ suggest olivine, clinopyroxene, apatite and ilmenite were fractionating or residual phases. The strong negative trends of $\mathrm{Ni}, \mathrm{Cr}$ and $\mathrm{V}$ against $\mathrm{SiO}_{2}$ also reflect the possible role of olivine and clinopyroxene, whereas negative $\mathrm{Sr}$ indicates plagioclase fractionation. The REE patterns, without significant Eu anomalies, suggest simultaneous crystallization of clinopyroxene/hornblende and plagioclase. The depletion of $\mathrm{Nb}$-Ta-Ti might be related to the involvement of titanite/ilmenite. The dominantly positive $\mathrm{Sr}$ anomalies on the multi-element spider diagrams, together with the absence or weakly negative $\mathrm{Y}$ anomalies, indicate the variable but dominant role of clinopyroxene/hornblende, with or without minor residual garnet.

The low $\mathrm{SiO}_{2}(<65 \mathrm{wt} \%)$ contents, coupled with high Mg-number (>0.39), Ni (20-46 ppm) and $\mathrm{Cr}$ (110-134 ppm) contents, preclude an ancient crustal source and suggest mafic to ultramafic rocks as the potential source. These characteristics, together with high to very high contents of incompatible elements (K, $\mathrm{Rb}, \mathrm{Ba}, \mathrm{Sr}, \mathrm{Zr}, \mathrm{Nb}, \mathrm{Y}, \mathrm{REE})$ even at low $\mathrm{SiO}_{2}(<55 \mathrm{wt} \%)$, argue for enriched ultramafic sources. The high $\mathrm{SiO}_{2}(>64 \mathrm{wt} \%)$ and low-Mg\# $(<0.39)$ of transitional TTGs means they are inconsistent as a potential source, as reflected in the $3^{*} \mathrm{CaO}$ $\mathrm{Al}_{2} \mathrm{O}_{3} /\left(\mathrm{FeO}_{\mathrm{t}}+\mathrm{MgO}\right)-5^{*}\left(\mathrm{~K}_{2} \mathrm{O} / \mathrm{Na}_{2} \mathrm{O}\right)$ ternary (Fig. 14a) diagram (Laurent et al., 2014). Interaction of slab melts generated at different depths with the overlying mantle wedge during their ascent is considered to be the source of sanukitoid magmas (Martin et al., 2005, 2010). Melting of mafic rocks at higher pressures leaving garnet-rich amphibolite or eclogite with rutile residue (Klemmen et al., 2002; Rapp et al., 1991, 2003) would generate melts with high $\mathrm{Al}_{2} \mathrm{O}_{3}$ (>15 wt\%) but low Mg\# and transition and HFSE. This is contrary to the observed low $\mathrm{Al}_{2} \mathrm{O}_{3}(13-15$ wt\%), but conversely high Mg\# (0.39-0.61) and transition elements, thus precluding high pressure melting of mafic rocks, leaving garnet-rich amphibolite or eclogite residue. Furthermore, several studies have shown that melting of thickened oceanic arc crust at different depths would generate melts of low- to high-Al TTGs as revealed by elemental data and experimental results with low $\mathrm{Mg} \#(<0.40)$ but variable $\mathrm{Sr} / \mathrm{Y}$ and $(\mathrm{La} / \mathrm{Yb})_{\mathrm{N}}$ ratios $($ Smithies et al., 2009; Hoffmann et al., 2011; Nagel et al., 2012; Polat, 2012; Jayananda et al., 2015, 2018). = 
Such a scenario fails to account for the observed low $\mathrm{SiO}_{2}(<60 \mathrm{wt} \%)$, but high $\mathrm{Ni}, \mathrm{Cr}, \mathrm{REE}$, $\mathrm{Ba}+\mathrm{Sr}$, and HFS elements (Zr, Hf, Nb, Ta, Sc, Y). Therefore, melting of mafic rocks with eclogite or garnet-amphibolite residue and thickened oceanic arc crust cannot account for the observed low $\mathrm{SiO}_{2}$, and high contents of both compatible and incompatible elements. Consequently, involvement of an enriched peridotitic mantle source is required for the generation of sanukitoid melts. Major enriched mantle input is reflected in the $\mathrm{Sr}+\mathrm{Ba}$ versus $\mathrm{FeO}_{\mathrm{t}}+\mathrm{MgO}$ diagram, where the majority of the samples plot in the enriched mantle field, with a few samples extending into the crustal melting field (Fig. 14b), which probably corresponds to minor crustal input or contamination.

The high $\mathrm{Th} / \mathrm{Ta}, \mathrm{Th} / \mathrm{Nb}, \mathrm{La} / \mathrm{Nb}, \mathrm{Ba} / \mathrm{Nb}$, and $\mathrm{Ba} / \mathrm{La}$ ratios of the sanukitoids suggest possible enrichment of sub-arc mantle reservoirs (Shirey and Hanson, 1984; Smithies and Champion, 2000). In situ $\mathrm{Hf}\left[\varepsilon_{\mathrm{Hf}}(\mathrm{T})=+4.5\right.$ to -3.2$]$ isotope data for zircons, together with whole rock $\mathrm{Nd}$ isotope data $\left[\varepsilon_{\mathrm{ENd}} \mathrm{T}_{(\mathrm{T})}=+1.93\right.$ to -1.26$]$ for the sanukitoids, are compatible with mantle (enriched or not) reservoirs with or without minor crustal input. Traces of ancient crustal input is evident in the sanukitoids in the Central block, as revealed by angular migmatitic enclaves and negative $\varepsilon \mathrm{Hf}_{(\mathrm{T})}$ and $\varepsilon \mathrm{Nd}_{(\mathrm{T})}$ values of a few samples, whereas sanukitoids in the Eastern block show positive $\varepsilon \mathrm{Hf}_{(\mathrm{T})}$ and $\varepsilon \mathrm{Nd}_{(\mathrm{T})}$ signatures, which is agreement with the absence of ancient $(>3000$ Ma) crust. The high to very high content of incompatible elements (LILE, LREE, HFSE), even at the lowest $\mathrm{SiO}_{2}(50 \mathrm{wt} \%)$, is also consistent with their derivation from enriched mantle reservoirs.

Elemental and isotope data reveal major mantle input in the origin of the sanukitoid magmas, but it is necessary to characterize the depth of melting and residual mineralogy of the mantle source. The moderately fractionated REE patterns of the majority of samples, without or with weak negative or positive Eu anomalies, together with positive $\mathrm{Sr}$ anomalies and negative $\mathrm{Nb}-\mathrm{Ta}-\mathrm{Ti}$ anomalies without any significant $\mathrm{Y}$ anomalies (see Figs. 11c, d), suggest melting close to or below the plagioclase stability field, with residual olivine, clinopyroxene, amphibole/phlogopite?, titanite and/or ilmenite, but minor residual garnet. This is consistent with the $\mathrm{Sr} / \mathrm{Y}$ versus $\mathrm{Y}$ and $(\mathrm{La} / \mathrm{Yb}$ ) versus $\mathrm{Yb}$ plots (Figs. 15a, b) suggesting minor or no residual garnet. The $\mathrm{Nb} / \mathrm{Ta}$ versus $\mathrm{Zr} / \mathrm{Sm}$ plot indicates low pressure melting with possible co-existing residual clinopyroxene, amphibole, and ilmenite (Figure not presented). To summarize, the field, elemental and isotope data of the sanukitoids from the Central block indicate derivation from chondritic to enriched mantle reservoirs that interacted with ancient crust, whereas the 
sanukitoids from the Eastern block were derived from a less enriched or chondritic to depleted mantle source that probably interacted with young juvenile crust, as reflected by the field and isotopic data.

\subsubsection{Ca. 2535 Ma Synplutonic mafic dykes}

Syn-plutonic mafic dykes correspond to the terminal phase of juvenile magmatism in the Central and Eastern Dharwar Craton and are synchronous with emplacement of anatectic granite, as revealed by field evidence (see Fig. 3j) and U-Pb zircon ages (see Fig. 8.2e). Most of these dykes are fragmented which indicates interaction with the granitoid host, as revealed in the field by the presence of biotite-rich rims. Petrographic characteristics (K-feldspar and quartz inclusions in clinopyroxene/hornblende) suggest these mafic melts were injected into crystallizing magma chambers at different stages of crystallization of the host (Jayananda et al., 2009, 2014; Gireesh et al., 2012). Two groups are defined on Harker diagrams (Fig. 10), wherein higher $\mathrm{SiO}_{2}(55-60 \mathrm{wt} \%)$ samples (hybrid facies?) define differentiation trends along with the sanukitoids, whereas the low $\mathrm{SiO}_{2}(48-51 \mathrm{wt} \%)$ samples form a cluster that corresponds to mafic injections without much interaction with the host, as they were probably injected during an advanced crystallization stage ( $>70 \%$ crystals) of the host. Their low $\mathrm{SiO}_{2}$ contents, together with moderate, high to very high content of compatible $(\mathrm{MgO}, \mathrm{Ni}, \mathrm{Cr})$ as well as incompatible (K, Ba, Sr, REE, Th, U, Zr, Y, Nb) elements, cannot be attributed to either melting of a downgoing slab in a subduction zone or to the melting of oceanic arc crust, but imply involvement of a peridotitic mantle source. Their high contents of incompatible elements cannot be explained by crustal contamination, as the samples with the lowest $\mathrm{SiO}_{2}(<50 \mathrm{wt} \%)$ contain the highest incompatible elements compared to the surrounding granitoid host. On the $3 * \mathrm{CaO}-$ $\mathrm{Al}_{2} \mathrm{O}_{3} /\left(\mathrm{FeO}_{\mathrm{t}}+\mathrm{MgO}\right)-5^{*}\left(\mathrm{~K}_{2} \mathrm{O} / \mathrm{Na}_{2} \mathrm{O}\right)$ ternary plot (Fig. 14a, after Laurent et al., 2014) these rocks plot in the high-K mafic source region, suggesting enriched reservoirs that were also reflected on the $\mathrm{Sr}+\mathrm{Ba}$ versus $\mathrm{FeO}+\mathrm{MgO}$ diagram (Fig. 14b; after Laurent et al., 2014) where they plot as vaugnerites, corresponding to enriched lithospheric mantle reservoirs, with two samples extending into the deep seated OIB field. In situ zircon $\mathrm{Hf}\left[\mathrm{\varepsilon Hf}_{(\mathrm{T})}=-1.6\right.$ to +5.0$]$ isotope and whole-rock $\mathrm{Nd}\left[\varepsilon_{\mathrm{Nd}} \mathrm{Cd}_{(\mathrm{T})}=+0.88\right.$ to -0.7$]$ indicate mainly enriched mantle reservoirs, except for three samples that show depleted mantle signatures (lower K, Ba, Sr, LREE). Three samples from the Central block with low to moderate total REE (32-171 ppm) show flat REE patterns without Eu anomalies, suggesting their derivation from shallow depleted to chondritic mantle. Their relatively unfractionated to highly fractionated REE patterns $\left[(\mathrm{La} / \mathrm{Yb})_{\mathrm{N}}=1.22\right.$ to 37.78], 
together with low to moderate $\mathrm{Sr} / \mathrm{Y}$ values and strong negative $\mathrm{Nb}-\mathrm{Ta}$ anomalies, argue for melting of peridotitic mantle at different depths (shallow to deep) with variable co-existing residual olivine, clinopyroxene, phlogopite, and ilmenite/rutile, without any significant garnet in the residue. The large variation in elemental abundances (low to very high $\mathrm{K}, \mathrm{Ba}, \mathrm{Sr}$, and LREE) in the syn-plutonic mafic dykes of the Central block can be attributed to heterogeneous sub-arc mantle, whereas moderate $\mathrm{K}, \mathrm{Ba}, \mathrm{Sr}$, and LREE in the Eastern block could be related to moderately enriched homogeneous arc mantle.

In summary, the 2670-2600 Ma transitional TTGs and 2570-2520 Ma sanukitoid intrusions are juvenile additions that are spatially and temporally related, as reflected in their elemental and isotopic compositions. However, a progressive increase of $\mathrm{K}_{2} \mathrm{O} / \mathrm{Na}_{2} \mathrm{O}, \mathrm{Rb}, \mathrm{Ba}, \mathrm{Sr}, \mathrm{Nb}, \mathrm{Zr}, \mathrm{Ti}, \mathrm{P}$ and Y from transitional TTGs to sanukitoids indicates their petrogenetic link, particularly the evolution of their mantle source reservoirs.

\subsubsection{Ca. 2535-2520 Ma Anatectic granites}

These rocks are present at the periphery of large juvenile granitoid intrusions and are found as small dykes traversing the migmatitic TTGs, as well as the banded transitional TTGs. Field evidence, such as diffuse contacts with the surrounding gneisses, suggests their derivation by remelting of crustal rocks. Zircon U-Pb ages show that anatectic granite emplacement immediately preceded emplacement of the hot sanukitoid magmas. Field evidence, such as evidence of mingling between anatectic granite and sanukitoid (Jayananda et al., 2014), and fluid inclusion data (Santosh et al., 1991), show that juvenile calc-alkaline magmas provided heat and a fluid source for deep crustal melting. The moderate to strong negative trends of $\mathrm{TiO}_{2}, \mathrm{Fe}_{2} \mathrm{O}_{3}$, $\mathrm{MgO}, \mathrm{CaO}, \mathrm{Na}_{2} \mathrm{O}, \mathrm{P}_{2} \mathrm{O}_{5}, \mathrm{Sr}, \mathrm{Ni}, \mathrm{Cr}$, and $\mathrm{V}$ on the Harker diagrams was likley related to involvement of plagioclase, hornblende/clinopyroxene, titanite/ilmenite and apatite as fractionating or residual phases. Their high $\mathrm{SiO}_{2}$ (>70 wt\%), K, Rb, Ba, and LREE contents, but low $\mathrm{Sr}$, could be attributed to anatexis of crustal rocks as suggested by the $3 * \mathrm{CaO}$ -

$\mathrm{Al}_{2} \mathrm{O}_{3} /\left(\mathrm{FeO}_{\mathrm{t}}+\mathrm{MgO}\right)-5 *\left(\mathrm{~K}_{2} \mathrm{O} / \mathrm{Na}_{2} \mathrm{O}\right)$ triangular diagram (see Fig. 14a). Isotopic data presented in this study, together with published data $\left[\varepsilon \mathrm{Ef}_{(\mathrm{T})}=-4.3\right.$ to -15.0$)$ and $\varepsilon \mathrm{Nd}_{(\mathrm{T})}=-0.5$ to -7.0$\left.)\right]$, indicate their derivation by melting of heterogeneous ancient crust (>3000 Ma) as well as newly formed juvenile crust (ca. 2700-2600 Ma). The moderate to strongly fractionated REE patterns with strong negative $\mathrm{Eu}\left(\mathrm{Eu} / \mathrm{Eu}^{*}=0.34-0.81\right)$ anomalies, together with negative $\mathrm{Ba}, \mathrm{Sr}, \mathrm{Nb}-\mathrm{Ta}$, and $\mathrm{Ti}$ anomalies, suggest major residual plagioclase + hornblende \pm clinopyroxene \pm garnet, with titanite/ilmenite. On the contrary, the large variation in $(\mathrm{La} / \mathrm{Yb})_{\mathrm{N}}$ values $(7.03-20$, excluding 
two outliers with values >50) and $\mathrm{Sr} / \mathrm{Y}(8-82)$, together with the absence of $\mathrm{Y}$ anomalies, preclude significant garnet in the source residue. Experimental work and geochemical modelling suggest that melting of alumina-rich crustal source rocks can generate higher $(\mathrm{La} / \mathrm{Yb})_{\mathrm{N}}$ and $\mathrm{Sr} / \mathrm{Y}$ ratios (Moyen, 2011), which may account for the few high $(\mathrm{La} / \mathrm{Yb})_{\mathrm{N}}$ and $\mathrm{Sr} / \mathrm{Y}$ values in the present study. In summary, the anatectic granites formed by reworking of ancient (>3000 Ma) together with newly formed crust (2700-2600 Ma) and are spatially associated with the emplacement of the hot sanukitoid magmas.

\subsection{Multi-stage crust accretion, continental growth and reworking}

Global zircon $\mathrm{U}-\mathrm{Pb}$ ages, together with in situ $\mathrm{Hf}$ isotope compositions and combined with whole-rock $\mathrm{Nd}$ isotope data, suggest high rates of continental crust production during the Archean through differentiation of the mantle (Belousova et al., 2010; Condie and Aster, 2010; Condie et al., 2017; Dhuime et al., 2012; Roberts and Spencer, 2014). Furthermore, zircon age peaks have been attributed to the generation of large continental masses through collision of crustal blocks produced at subduction zones (Hawkesworth et al., 2010; Condie, 2014). Global 'super' events of continental crust production have been documented at ca. $2700 \mathrm{Ma}, 1900 \mathrm{Ma}$ and $1200 \mathrm{Ma}$ (Condie, 2000).

The zircon $\mathrm{U}-\mathrm{Pb}$ ages presented in this study, together with published zircon ages from the Central and Eastern Dharwar Craton, show episodic juvenile crustal accretion and multi-stage continental growth at ca. 3360-3200 Ma, 3000-2960 Ma, 2700-2600 Ma and 2570-2520 Ma (Friend and Nutman, 1991; Peucat et al., 1993, 2013; Balakrishnan et al., 1999; Rogers et al., 2007; Chardon et al., 2011; Bidyananda et al., 2016; Anand and Balakrishnan, 2010; Anand et al., 2014; Dey et al., 2014, 2016, 2018; Jayananda et al., 1995,2000, 2013a,2018; Khanna et al.,2014, 2016; Ratheesh Kumar et al., 2016; Mohan et al., 2013, 2014; Nasheeth et al., 2015). These juvenile accretion events are spatially associated with crustal reworking, including metamorphism at ca. $3200 \mathrm{Ma}, 3000 \mathrm{Ma}, 2620 \mathrm{Ma}, 2520 \mathrm{Ma}$ (Mahabaleswar et al., 1995; Peucat et al., 2013; Jayananda et al., 2011, 2013a). Furthermore, U-Pb zircon data from Neoarchean juvenile crust indicate a crude age zonation from west to east, wherein the crust progressively become younger with more primitive juvenile signatures and lesser degrees of enrichment to the east (see Fig. 17).

The oldest preserved Archean basement is confined to the westernmost part of the Central block represented by the migmatitic TTGs that accreted in two stages, corresponding to significant continental growth. Our SHRIMP U-Pb zircon data and published zircon age data for the 
migmatitic gneisses from the northern part of the study area (Chardon et al., 2011; Jayananda et al., 2013a; Nasheeth et al., 2015), suggest that the oldest crust corresponds to the earliest continental growth at ca. 3380-3230 Ma. Furthermore, detrital zircons from metapelite from the western (Jayananda et al., 2013a) and eastern margins of the Closepet batholith record U-Pb ages ranging from 3350-3200 Ma (Jayananda unpub data). In the southern part of the Central block, $\mathrm{U}-\mathrm{Pb}$ zircon ages for the migmatitic gneisses from the Bangalore-Kolar and Kabbaldurga - B.R. Hills region reveal two stages of magmatism that contributed to significant crustal growth at ca. 3360-3200 Ma and 3000-2960 Ma (Friend and Nutman, 1991; Jayananda et al., 2000; Peucat et al., 2013; Mahabaleswar et al., 1995; Bidyananda et al., 2011, 2016; Ratheesh Kumar et al., 2016). A few younger U-Pb ages documented from rims on old zircons at ca. $2700 \mathrm{Ma}$, ca. 2600 Ma and ca. $2500 \mathrm{Ma}$, coincide with ca. $2700 \mathrm{Ma}$ greenstone volcanism, $2600 \mathrm{Ma}$ transitional TTG accretion and 2540 Ma sanukitoid magmatism, respectively (Balakrishnan et al., 1999; Jayananda et al., 2000, 2013a; Mojzsis et al., 2003; Yang and Santosh, 2015; Peucat et al., 2013). In situ $\mathrm{Hf}$ isotope $\left[\mathrm{EHf}_{(\mathrm{T})}=+5\right.$ to -7$\left.)\right]$ data for zircon and whole-rock $\mathrm{Nd}$ isotope data $\left[\varepsilon_{\mathrm{Nd}}(\mathrm{T})=+3\right.$ to -1.6] data suggest significant continental growth at ca. 3360-3150 Ma and 3000-2960 Ma involving juvenile addition as well as minor ancient crustal contamination (Bhaskar Rao et al., 2003; Peucat et al., 2013; Ratheesh Kumar et al., 2016; Bidyananda et al., 2016). In summary, the $\mathrm{U}-\mathrm{Pb} / \mathrm{Pb}-\mathrm{Pb}$ ages of magmatic and detrital zircons from the oldest basement in the Central block show two stages of continental growth at ca. 3360-3150 Ma and 3000-2960 Ma, prior to Neoarchean juvenile accretion. However, the 3380-3150 Ma komatiite-dominated greenstone assemblages with contemporaneous TTGs documented in the Western block (Jayananda et al., 2008; Maya et al., 2017) are absent in the Central block. This suggests an independent crustal history for the Central and Western blocks of the Dharwar Craton. Although some workers (e.g. Bidyananda et al., 2011, 2016) argued that both the Western and Eastern Dharwar Craton (based on their data presented only for the Central block up to the Kolar greenstone belt) evolved simultaneously but that fundamental differences exist in lithological assemblages, thermal records, age zonation and accretion histories of the three micro-blocks (Jayananda et al., 2018).

The zircon $\mathrm{U}-\mathrm{Pb}$ ages when combined with in situ $\mathrm{Hf}$ and Nd isotope data for transitional TTGs, together with published data, reveal a major episode of juvenile felsic crust addition contributing to high rates of continental growth in both the Central and Eastern blocks at ca. 2670-2580 Ma (Krogstad et al., 1991; Balakrishnan et al., 1999; Mojzsis et al., 2003; Chardon et al., 2011; Dey et al., 2014, 2016; Yang and Santosh, 2015). U-Pb zircon data indicate widespread transitional TTG accretion in the Central block at ca. 2670-2600 Ma, but at ca. 2590-2580 Ma in the Eastern 
1070

1

21071

3

41072

51073

71074

8

91075

10

111076

12

131077

14

151078

161079

17

181080

19

20

211081

22

231082

24

25

26

27

281085

29

301086

31

321087

33

341088

35

36

37

38

39

40

411092

42

43

441093

45

46

47

48

491096

50

511097

52

531098

54

551099

56

571100

58

block (see Figs. 8.1 and 8.3). This indicates that transitional TTG accretion in the Eastern block was initiated during the waning stages of transitional TTG formation in the Central block. On the other hand, published geochronological data for adjoining greenstone volcanic assemblages (see Fig. 17) reveal bimodal age distributions with ca.2745- 2670 Ma mafic to felsic volcanism and minor felsic volcanism at 2570-2545 Ma (Balakrishnan et al., 1990; Zacharaiah et al., 1995; Nutman et al., 1996; Balakrishnan et al., 1999; Naqvi et al., 2002; Anand and Balakrishnan, 2010; Sarma et al., 2012; Jayananda et al., 2013b; Khanna et al., 2014, 2016; Dey et al., 2018; Yang and Santosh, 2015). This indicates that transitional TTG accretion was immediately preceded by ca. 2745-2670 Ma greenstone volcanism in the Central and Eastern blocks. Consequently, ca. 2745-2670 Ma greenstone volcanism and 2670-2600 Ma transitional TTG accretion together contributed to large-scale continental growth.

Calc-alkaline juvenile granitoids of sanukitoid affinity cover nearly 40 percent of the surface area of the Central and Eastern blocks. The U-Pb zircon ages of the present study, together with published ages on calc-alkaline granitoids, define major outbursts of crust accretion that contributed to peak continental growth between 2570-2520 Ma (Peucat et al., 1993, 2013; Jayananda et al., 1995, 2000, 2013a; Chardon et al., 2002, 2011; Rogers et al., 2007; Anand et al., 2014; Mohan et al., 2014; Dey et al., 2012, 2014, 2016; Yang and Santosh, 2015). The Nd$\mathrm{Sr}-\mathrm{Hf}$ isotope data of these granitoids suggest major differentiation of heterogeneous mantle reservoirs with variable, but minor, older crustal input. This juvenile magmatic accretion was contemporaneous with felsic volcanism in the adjoining greenstone belts (Jayananda et al., 2013b; Dey et al., 2015; Yang and Santosh, 2015). Consequently, calc-alkaline magmatism of sanukitoid affinity, together with contemporaneous felsic volcanism, have likewise contributed to peak continental growth between 2570-2520 Ma (see Fig. 17).

Combined geochronological and isotope data reveal a complex evolutionary history with multistage crustal growth involving juvenile magmatic accretion, crustal reworking and metamorphism. Isotopic age data record multiple stages of crustal growth (ca. 3360-3150 Ma, 3000-2960 Ma, 2700-2600 Ma, 2570-2520 Ma) in the Central block, whilst only two episodes of crustal growth are evident in the Eastern block at 2700-2670 and 2580-2535 Ma. These major episodes of crustal growth were spatially linked to crustal reworking and medium- to high-grade metamorphism, as revealed by texturally controlled in situ monazite and U-Pb zircon ages. In the Central block, the earliest thermal event is dated at $3200-3140 \mathrm{Ma}$, which corresponds to the terminal phase of migmatitic TTG accretion (this study; Jayananda et al., 2013a). The second thermal event, defined by upper amphibolite to granulite facies metamorphism, occurred at ca. 
1103

1

21104

3

41105

51106

71107

8

91108

10

111109

12

131110

14

$15^{1111}$

16

171112

18

191113

20

211114

22

231115

24

$25^{1116}$

26

27

281118

29

301119

31

321120

33

34

351121

36

371122

38

391123

40

$41^{1124}$

421125

441126

45

461127

47

481128

49

501129

51

521130

531131

54

551132

56

571133

58

591134

60

61

62

63

64

65

$2960 \mathrm{Ma}$ as revealed by discordant zircon ages (Mahabaleswar et al., 1995; Jayananda and Peucat, 1996) and this is spatially linked to 3000 Ma crustal accretion. Metamorphism and dehydration melting of pelitic rocks under granulite facies to UHT conditions $\left(800-900^{\circ} \mathrm{C}, 5-7\right.$ kbar), documented in the Central block at 2620 Ma (Jayananda et al., 2011, 2013a), coincide with the accretion of transitional TTG. However, the pre-2500 Ma thermal event is not documented in the Eastern block. Both the Central and Eastern blocks underwent a coeval amphibolite to granulite facies thermal event at ca. $2513 \mathrm{Ma}$, followed by slow cooling to 2400 Ma (Jayananda et al., 2013a; Peucat et al., 1989, 2013). In summary, the Eastern Dharwar Craton preserves records of multi-stage crustal growth and reworking events.

Globally, $2700 \mathrm{Ma}$ zircon age peaks have been attributed to high rates of continental growth as a result of craton collisions (Condie et al., 2017). However, such zircon age peaks have not been documented in the Dharwar Craton. Only a few whole-rock isochrons and zircon ages of ca. 2700 Ma have been reported for the greenstone volcanics (Balakrishnan et al., 1990, 1999; Khanna et al., 2014, 2016; Naqvi et al., 2002; Jayananda et al., 2013b). In contrast, the U-Pb zircon ages of 2670-2600 Ma for the transitional TTGs, and the following 2570-2520 Ma outburst of calc-alkaline granitoid magmatism, correspond to major juvenile crustal addition that contributed to large-scale Neoarchean continental growth. Consequently, the major global peak in continental growth at ca. $2700 \mathrm{Ma}$ is craton specific and not evident in the Dharwar Craton.

\subsection{Mantle evolution through the Neoarchean: Implications for enrichment of source reservoirs}

Globally, several studies have attributed mantle enrichment to (i) melting of sediments in subduction zones; (ii) interaction of slab-derived melts with overlying mantle (Prouteau et al., 2001; Sajona et al., 2000; Moyen et al., 2003a; Wang et al., 2009); (iii) fluid flux from slab dehydration (Heilimo et al., 2010); or (iv) metasomatism related to plume/asthenosphere upwelling (Oliveira et al., 2011; Jayananda et al., 2018). Magmas generated from sub-arc mantle that was modified by melting of subducted sediments are characterized by low $\mathrm{Sr} / \mathrm{Ce}, \mathrm{Ce} / \mathrm{Yb}$ and $\mathrm{Sr} / \mathrm{Y}$ ratios (Tatsumi, 2006; Shimoda et al., 1998), whereas melts generated from arc mantle enriched by fluids derived from subduction zones exhibit $\mathrm{Sr} / \mathrm{Ce}(\sim 20)$ and $\mathrm{Ce} / \mathrm{Pb}$ values $<20$ (Chauvel et al., 1995). The wide range of $\mathrm{Sr} / \mathrm{Ce}$ ratios of 2.74-16.96, $\mathrm{Ce} / \mathrm{Pb}$ values of 3.43-9.76 and $\mathrm{Sr} / \mathrm{Y}$ values ranging from 30-160 obtained in this study are not fully consistent with mantle enrichment either through fluids or sediment recycling in a subduction zone. This is supported by positive $\varepsilon \mathrm{Nd}_{(\mathrm{T})}$ and $\varepsilon \mathrm{Hf}_{(\mathrm{T})}$ values for the majority of the sanukitoid samples. Slab-derived fluids or melt induced mantle enrichment have been proposed by many workers (Kamber et al., 2002; 
Moyen et al., 2003; Komiya and Maruyama, 2007), wherein enrichment of supra-subduction zone mantle results in depletion of Ta and $\mathrm{Hf}$ relative to $\mathrm{La}$ and $\mathrm{Sm}$ by fluid induced metasomatism.

In the Eastern Dharwar Craton, the differentiation of crust from the mantle in the Neoarchean occurred at ca. $2750-2520 \mathrm{Ma}$ in the form of greenstone volcanism, transitional TTGs, calcalkaline magmatism of sanukitoid affinity and synplutonic mafic dykes. It is therefore important to constrain the coupled evolution of the crust-mantle system and enrichment of mantle reservoirs through time.

\subsubsection{Constraints from greenstone volcanism (2746-2670 Ma)}

Greenstone volcanism is bimodal in age distribution, with the ultramafic and mafic volcanism and associated minor felsic volcanism, representing the earlier episode at ca. 2750-2670 Ma, whereas dominantly felsic volcanism occurred between 2580-2545 Ma. Elemental and isotope $(\mathrm{Pb}, \mathrm{Sr}, \mathrm{Nd}, \mathrm{Hf})$ data for the greenstone volcanics provide important constraints on mantle evolution, particularly the enrichment of source reservoirs to the transitional TTGs, sanukitoids and syn-plutonic mafic dykes. The Central block recorded only the earlier episode of volcanism (komatiite-basalt-andesite-dacite) in the Sandur-Ramagiri-Penakacherla-Kustagi-Hungund greenstone belts at ca. 2750-2670 Ma (Zacharaiah et al., 1995; Nutman et al., 1996; Balakrishnan et al., 1999; Naqvi et al., 2002). On the contrary, two episodes of volcanism are documented in the Eastern block, with ca. 2700 -2696 Ma komatiite-basalt volcanism in the Kolar, Kadiri, Veligallu, Jonnagiri, Gadwal and Hutti greenstone belts, and minor ca. 2580-2545 Ma felsic volcanism in the Kolar, Kadiri, Gadwal, Hutti and Peddavura greenstone belts.

The 2746-2702 Ma komatiitic to high-Mg basaltic assemblages in the Central block appear to be generated in hot-spot environments, forming oceanic islands/plateaus, whereas the associated calc-alkaline basalts, adakites-rhyolites originated by melting of young subducted oceanic crust in a convergent margin setting (Zacharaiah et al., 1996a; Manikyamba and Kerrich, 1992; Naqvi et al., 2002). Elemental ratios of the Sandur greenstone komatiites and basalts $(\mathrm{Nb} / \mathrm{Th}<8$ to $>8)$ have been interpreted in terms of their derivation from a heterogeneous plume source, with the higher contents of incompatible elements of associated adakites and dacites attributed to a hybridized mantle wedge source in an arc setting, which, upon eruption, accreted to a plumederived oceanic plateau (Manikyamba et al., 2008). The volcanic-dominated ca. 2746-2702 Ma Ramagiri-Penakacherla-Kushtagi-Hungund greenstone sequences are heterogeneous. The alkaline $(\sim 8.0 \mathrm{wt} \%)$ character of basalts from the Penakacherala greenstone belt, together with 
their high $\mathrm{Mg \#}(0.70-0.58), \mathrm{TiO}_{2}(2.3-2.1 \mathrm{wt} \%)$, and REE contents, when coupled with their fractionated patterns $\left[(\mathrm{La} / \mathrm{Yb})_{\mathrm{N}}=23-29\right]$ and weak negative $\mathrm{Nb}$ anomalies and higher $\mathrm{Zr} / \mathrm{Hf}$ ratios (Kerrich and Manikyamba, 2012), all point to a primitive mantle source. Immediately south of this belt, variable LREE contents and $\mathrm{Nd}$ isotope data $\left(\varepsilon \mathrm{Ed}_{(\mathrm{T})}=+2.0\right.$ to +3.5$)$, with some anomalous values linked to post-crystallization alteration) of metabasalts from the Ramagiri greenstone belt (Fig. 2) are attributed to distinct mantle sources (depleted to enriched?), with oceanic slab-derived fluids playing a major role in enrichment of LREE and LILE (Zacharaiah et al., 1997). To summarize, the elemental and isotope data of the 2750-2700 Ma volcanic sequences in the Central block reveal mantle heterogeneity (depleted to enriched), with enrichment of mantle reservoirs through slab-derived fluids at ca. $2700 \mathrm{Ma}$.

In the Eastern block, incompatible trace element contents and $\mathrm{Nd}$ and $\mathrm{Pb}$ isotope compositions of komatiite and high-Mg basalts from the Kolar greenstone belt reveal heterogeneous sources (LREE depleted in the west and LREE enriched to the east), with long-term depletion of the mantle and LREE enrichment prior to melting of the mantle to form the eastern volcanics (Balakrishnan et al., 1990; Krogstad et al., 1989). More recent U-Pb zircon data, together with $\mathrm{Nd}$ isotope data, for the Kolar greenstone volcanics reveal ancient crustal contamination (Jayananda et al., 2013b). Immediately north in the Kadiri greenstone belt (Fig. 2), two types of basalts are recognised, one with flat LREE and the other with LREE-enriched patterns, Both display Th, U, and LILE enrichment with negative $\mathrm{Nb}, \mathrm{Zr}$, Hf, and Ti anomalies, together with high $\mathrm{Th} / \mathrm{Nb}, \mathrm{La} / \mathrm{Nb}$ and $\mathrm{Ce} / \mathrm{Yb}$ ratios, attributed to enrichment of arc mantle through slab-derived fluids and sediment melting (Manikyamba et al., 2015b). Furthermore, Dey et al. (2016) showed that volcanic suites in the Kadiri greenstone belt have flat REE patterns with minor negative $\mathrm{Nb}$ Ta anomalies, interpreted as rocks generated in a mantle plume-derived oceanic plateau, whilst high Mg\# (0.00-0.52), Cr, and Ni, coupled with HFSE depletion and LREE enrichment, was attributed to their derivation from a metasomatized mantle wedge overlying a subducting slab in a continental margin setting. Further north, compositionally different (high-Mg, low-Nb, high $\mathrm{Nb}$ ) basalts from the Jonnagiri greenstone belt show enrichment in LREE/LILE and depletion in HFSE, which have been attributed to partial melting of a hybridized mantle wedge through slab dehydrated fluids (Manikyamba et al., 2014).

Elemental data (high $\mathrm{Mg} \#$ 0.89, $\mathrm{Cr}=2290-3855 \mathrm{ppm}$ and $\mathrm{Ni}=604-966 \mathrm{ppm}$ ), together with depletion of REE and $\varepsilon \mathrm{Hf}_{(\mathrm{T}=2696 \mathrm{Ma})}=+3-0$ to +6.5 for ultramafic volcanics from the Veligallu greenstone belt, reveal long-term depletion of the mantle reservoirs (Khanna et al., 2016). 
However, $\mathrm{Nd}$ isotopes $\left[\left(\varepsilon_{\mathrm{Nd}} \mathrm{N}_{(\mathrm{T})}=+0.6\right.\right.$ to +1.1$\left.)\right]$, coupled with negative $\mathrm{Nb}$ anomalies and elevated $\mathrm{Th} / \mathrm{Yb}$ and LREE contents of basalts from this belt suggest derivation from slightly depleted to metasomatized mantle through subducted slab-derived fluids in an arc setting (Dey et al., 2018). In the central part of the Eastern block, Hf-Nd isotope compositions Hf $\left[\left(\varepsilon \mathrm{Hf}_{(\mathrm{T})}=+1.6\right.\right.$ to +8.7$] ; \mathrm{Nd}\left[\left(\varepsilon \mathrm{Nd}_{(\mathrm{T})}=-0.1\right.\right.$ to +3.0$]$ of volcanic assemblages (tholeiitic, calcalkaline basalts to boninites) from the Gadwal greenstone belt are consistent with a depleted mantle source that evolved over a protracted period.

In the northern part of the Eastern block, metabasalts from the ca. 2700 Ma Hutti greenstone belt have both enriched and depleted LREE signatures, together with variable $\mathrm{Nb}, \mathrm{Ta}, \mathrm{P}$, and $\mathrm{Ti}$ anomalies, high $(\mathrm{La} / \mathrm{Yb})_{\mathrm{N}}$ and $\mathrm{Zr} / \mathrm{Sm}$, but low $\mathrm{Nb} / \mathrm{Ta}$, that have been explained through derivation from heterogeneous mantle reservoirs (depleted to chondritic or slightly enriched) whereby mantle wedge enrichment was caused by slab-derived fluids (Manikyamba et al., 2009). In addition, whole rock $\mathrm{Pb}, \mathrm{Sr}$ and $\mathrm{Nd}$ isotope data for the ca $2700 \mathrm{Ma}$ basaltic rocks from the Hutti greenstone belt indicate long term depletion of mantle reservoirs (Anand and Balakrishnan, 2010).

In summary, the incompatible elemental data, together with $\mathrm{Pb}, \mathrm{Sr}, \mathrm{Nd}$, and $\mathrm{Hf}$ isotope data presented above, argue for the existence of heterogeneous (depleted to chondritic to enriched) mantle reservoirs at ca. $2700 \mathrm{Ma}$ and likely enrichment of the mantle through slab-derived fluids/melts or sediment melting in a subduction zone. Elemental and $\mathrm{Nd}$ isotope data for the ca. 2700 -2670 Ma greenstone volcanics in the Central block indicate a high degree of enrichment of the mantle, with possible contribution from detritus derived from >2700 Ma pre-existing crust. The degree of enrichment of the source was less in the Eastern block, as revealed by elemental and isotope data from the ca. 2700 and 2580-2545 Ma volcanic assemblages that were erupted either as oceanic plateaus or in intra-oceanic arc settings.

\subsubsection{Constraints from transitional TTGs (2670-2600 Ma) and sanukitoids (2570-2520 Ma)}

The U-Pb zircon ages presented in this study, together with published data, show that transitional TTG magmatism at 2670-2600 Ma was immediately followed by 2570-2520 Ma calc-alkaline magmatism of sanukitoid affinity, including syn-plutonic mafic dykes. A shift in elemental composition occurred with the change from transitional TTGs to sanukitoids, with an increase in abundance of both incompatible elements ( $\mathrm{Rb}, \mathrm{K}, \mathrm{Ba}, \mathrm{Sr}, \mathrm{Zr}, \mathrm{Y}$, and LREE) and compatible elements (Mg\#, Ni and Cr). This implies that transitional TTGs and sanukitoids are genetically 
linked with an increase in peridotitic mantle input at ca. 2670-2520 Ma. Furthermore, elemental and $\mathrm{Nd}-\mathrm{Hf}$ isotope data for these two juvenile magmatic suites in the Central block originated from depleted to highly enriched reservoirs, whereas the magmatic suites in the Eastern block were derived from depleted to chondritic reservoirs. When coupled with distinct thermal records and accretion histories, including greenstone volcanism (Manikyamba and Kerrich, 2012), it reveals that large-scale mantle heterogeneity existed in the Eastern Dharwar Craton during the Neoarchean. Thus, it is necessary to account for this mantle heterogeneity and the evolution of mantle sources for the transitional TTGs and sanukitoids.

In the Eastern Dharwar Craton, strain fabric analysis, petrological data and elemental and isotope constraints favour the convergence of lithosphere in a plate tectonic regime, leading to building of oceanic and continental arcs at ca. $2700 \mathrm{Ma}$ (Balakrishnan et al., 1999; Chadwick et al., 2000, 2007; Manikyamba et al., 2017; Dey et al., 2015; Jayananda et al., 2018). During the Neoarchean, melting of subducted oceanic crust along with continent-derived detritus in an arc setting would generate melts enriched in incompatible elements. These enriched slab melts could interact and enrich overlying arc mantle in incompatible elements during their ascent. Melting of the down-going subducted slab at deeper levels $(\sim 80-100 \mathrm{~km})$ would produce much hotter mafic magmas that, upon their ascent to the crust-mantle boundary, would induce melting of enriched sub-arc mantle and the base of the newly-formed arc crust, generating the magmatic precursors of the transitional TTGs at ca. 2670-2600 Ma. Furthermore, elemental data for the enriched mafic volcanics (e.g. alkaline basalts in the Penakacherla greenstone belt; Kerrich and Manikyamba, 2012) indicate possible derivation from ocean island basalt (OIB) sources and these could also enrich the shallow mantle during their ascent. Consequently, the magmatic precursors of transitional TTGs originated from composite sources enriched by slab-derived magmas and through deep mantle-derived enriched mafic magmas.

Thus, transitional TTG accretion was immediately followed by sanukitoid magmatism between 2570-2520 Ma in an arc setting and involving a dominantly mantle source, with only minor ancient crustal or newly formed arc crust input. The majority of the studied sanukitoid samples display depletion of Ta relative to $\mathrm{La}$, but do not show depletion of $\mathrm{Hf}$ relative to Sm. Thus, mantle enrichment cannot be explained entirely by slab-derived fluids. Instead, melt induced enrichment of a mantle source would lead to depletion of Ta compared to La and enrichment of Hf relative to Sm (LaFleche et al., 1998), as documented for the Taishan sanukitoids from the North China Craton (Wang et al., 2009). The sanukitoid samples from the Eastern Dharwar Craton exhibit $(\mathrm{Ta} / \mathrm{La})_{\mathrm{N}}$ values of $0.13-0.89$ and $(\mathrm{Hf} / \mathrm{Sm})_{\mathrm{N}}$ values of $0.21-0.98$ and they plot in 
the field of melt-induced mantle enrichment, with a few samples extending into the field of fluidrelated subduction metasomatism (Fig. 18, after LaFleche et al., 1998). Although it is difficult to provide a straightforward criterion to discriminate fluid or melt involvement in peridotitic mantle enrichment, it nevertheless appears that interaction of melts with peridotitic mantle played a significant role in the study area, as revealed by the $(\mathrm{Ta} / \mathrm{La})_{\mathrm{N}}$ versus $(\mathrm{Hf} / \mathrm{Sm})_{\mathrm{N}}$ plot (Fig. 18), although the role of fluids cannot be totally ruled out. In the Eastern Dharwar Craton, continued subduction between 2700-2600 Ma, with eventual slab breakoff, led to asthenosphere upwelling, causing widespread melting of enriched sub-arc mantle and thereby generating hot enriched sanukitoid magmas. Upon their emplacement, these magmas variably interacted with both ancient crust and newly-formed juvenile crust in the Central block, but only with young juvenile crust in the Eastern block. Although the sanukitoids in the Central and Eastern blocks show similar elemental characteristics, those in the Central block show strong enrichment, as well as extensive interaction with old crust, as also indicaed by the field relations (Fig. 3a), and distinctive elemental features, including several negative $\varepsilon \mathrm{Nd}_{(\mathrm{T})}$ and $\varepsilon \mathrm{Hf}_{(\mathrm{T})}$ values (see supplementary tables $2 \& 4$ ) when compared with the Eastern block. This is consistent with the $\mathrm{U}-\mathrm{Pb}$ zircon ages and isotope data from the Eastern block, which indicate the absence of ancient $(>2.75 \mathrm{Ga})$ crust. Syn-plutonic mafic dykes were injected during the terminal stage of sanukitoid magmatism and the majority of samples show moderate to very high contents of $\mathrm{K}, \mathrm{Rb}, \mathrm{Ba}, \mathrm{Sr}$, LREE, Nb, Zr, Hf, Ta, and Ti despite their low $\mathrm{SiO}_{2}$ contents (see Figs.10, 11g, h, j; 14b) implying the existence of enriched mantle at the end of the Archean. Consequently, the above features show progressive enrichment of mantle reservoirs throughout the Neoarchean, probably through slab-derived melts/fluids (see Fig. 18).

\subsection{Evolving geodynamic processes through the Neoarchean: implications for assembly of crustal blocks, orogenic plateau formation and cratonization}

The geodynamic context of Archean crustal accretion, continental growth and craton formation are much debated topics. Numerous models, including stagnant lid through mobile lid to emergence of modern style plate tectonics, have been proposed for Archean crust formation and continental growth (for reviews see Bedard, 2018; Wyman, 2018; Cawood et al., 2018 and references therein). Multidisciplinary studies involving petrological data, strain fabric analysis, and numerical, thermo-mechanical and analogue modelling have provided important insights into Archean geodynamic processes as well as the mechanical behaviour of the Archean crustmantle system (Smithies et al., 2005; Chardon et al., 2009, 2011; Gerya, 2014; Sizova et al., 2014, 2015; Thebaud and Rey, 2013; Korenaga, 2018; Moyen and Laurent, 2018). 
Geodynamic evolution of Archean crust in the Dharwar Craton has likewise been the subject of much discussion over the past two decades. Contrasting models based on petrological and elemental data have been proposed for the Neoarchean evolution of the Eastern Dharwar Craton (Jayananda et al., 2000, 2013, 2018; Harish Kumar et al., 2003; Maibam et al., 2016; Manikyamba and Kerrich, 2012; Dey et al., 2014, 2018; Santosh and Li, 2018; Pandey et al., 2018), although only a few models are based on regional structural analysis (Bouhallier et al., 1993, 1995; Chadwick et al., 2000, 2007; Chardon et al., 1996, 1998, 2002, 2008, 2011) and geophysical data (Gupta et al., 2003; Borah et al., 2014; Ravi Kumar et al., 2018; Mandal et al., 2018; Vijaya Rao et al., 2015). The three most popular models include horizontal motion of plates similar to modern style plate tectonics (Chadwick et al., 2000, 2007; Santosh and Li, 2018), mantle plume-based vertical motions (Bouhallier et al., 1993, 1995; Chardon et al., 1996, 1998, 2002; Jayananda et al., 2000), and a combination of plume-arc processes (Dey et al., 2018; Harish Kumar et al., 2003; Jayananda et al., 2008, 2013, 2018; Manikyamba and Kerrich, 2012). Further, based on detailed strain fabric analysis and zircon geochronology, Chardon et al. (2011) proposed westward convergence of hot orogenic crust that would generate sub-horizontal lamination and strong seismic reflectivity (Vijay Rao et al., 2015; Mandal et al., 2018).

The studied corridor through the Central and Eastern Dharwar Craton records a complex geological history and any model proposed has to account for the observed west to east age zonation patterns, changes in the composition of felsic rocks from TTGs, through transitional TTGs, to sanukitoids, the low pressure and high temperature metamorphic record and seismic reflectivity. Horizontal tectonic models, but with different polarity of subduction involving either westward oblique convergence (e.g. Chadwick et al., 2000, 2007) or eastward subduction (Bidyananda et al., 2016; Santosh and Li, 2018; Li et al., 2018b), have been proposed to explain Neoarchean crustal accretion and northward-trending fabrics. The westward convergence of oceanic crust beneath the Western Dharwar Craton is consistent with the observed age zonation patterns, crustal flow, metamorphic record (low-P and HT to UHT) to the east, but fails to provide a satisfactory explanation for ca. 2700 Ma komatiite volcanism documented in the Sandur, Kolar and Veligallu greenstone belts. On the other hand, based on petrologic and elemental data some workers have proposed eastward convergence of oceanic lithosphere (Ratheesh Kumar et al., 2016; Santosh and Li, 2018; Li et al., 2018b). A combined plume-arc accretion model was proposed for the 2700-2500 Ma period of evolution in the Eastern Dharwar, where komatiite-tholeiite volcanism was attributed to a plume with TTG accretion occurring in the intervening arcs (Harish Kumar et al., 2003; Manikyamba and Kerrich, 2012; Jayananda et 
al., 2013b, 2018; Dey et al., 2018). We discuss the evolving Neoarchean geodynamic processes in terms of the combined plume-arc model, but followed by orogenic plateau formation through assembly of micro-blocks and final cratonization within the regional framework of a Neoarchean hot orogen (Chardon et al., 2011).

Geological and geophysical data reveal thick old crust (40-54 km) in the Western block, relatively thin crust (38-33 km) with both old and young juvenile components in the Central block, and thin $(32-35 \mathrm{~km})$ juvenile crust in the Eastern block. This observation is consistent with the distribution of moderate- to high-pressure metamorphic assemblages (Rollinson et al., 1981; Iswar Kumar et al., 2016; Jayananda et al., 2013a) and magmatic epidote-bearing ca.3000 Ma plutons in the Western block (Jayananda et al., 2019) and low-pressure, but high to ultrahigh temperature assemblages, in the Central and Eastern blocks. The Chitradurga boundary shear zone separating the Western and Central blocks is interpreted as a major tectonic boundary (Chadwick et al., 2000; Chardon et al., 2011; Jayananda et al., 2006, 2013b) where westward convergence of hot oceanic lithosphere has resulted in addition of hot juvenile magmas, causing extensive melting and lateral constructional flow of hot orogenic crust on weaker mantle lithosphere (Chardon et al., 2011), and producing strong seismic reflection patterns (Mandal et al., 2018). In this scenario, the Chitradurga boundary shear zone acted as a 'wall' between the already cratonized colder Western block and hot crust undergoing lateral constrictional flow on weaker mantle in the Central block between 2570-2520 Ma (Chardon et al., 2011). The section of the Central and Eastern blocks that was the focus of this study displays distinct thermal records and accretionary histories prior to $2600 \mathrm{Ma}$ (Jayananda et al., 2013a). However, both these crustal blocks formed part of a wide Neoarchean hot orogen between 2600-2500 Ma. We propose a model of secular changes in geodynamic evolution through hotspot magmatism, leading to oceanic plateaux formation, followed by westward convergence of intervening slabs producing the arc crust and eventual assembly of crustal blocks into a cratonic framework in the context of wide hot orogen (Chardon et al., 2011). In this model (Fig. 19a) melting at a mantle hot spot between ca. 2750-2700 Ma beneath ancient (3300-3000 Ma) crust of the Central block generated komatiite and alkali basalt magmas, leading to development of the Sandur and Ramagiri-Penakacherla greenstone basins, whilst komatiite to high-Mg basalt magmas erupted in oceanic environments producing volcanic plateaux (e.g. the Kolar, Kadiri, Veligallu, Gadwal greenstone belts) in the Eastern block. Simultaneous westward convergence of intervening oceanic crust beneath the Western and Central blocks led to the development of the ca. 2740 2650 Ma Chitradurga back-arc basin (Kumar et al., 1996; Russel et al., 1991; Nutman et al., 
1996; Jayananda et a., 2013b) and the 2740 Ma Javagondanahalli basin (Jayananda et al., 2011b) along the eastern margin of the Western block and the Sandur-Ramagiri-Penakacherla-Hungund belt in an active continental margin setting (Fig. 19a). To the east, hotspot volcanism, followed by westward convergence of intervening oceanic crust beneath the Central block, produced intermediate to felsic magmas that upon emplacement built arc crust adjacent to mafic to ultramafic crust in the continental (e.g. Sandur) and oceanic (e.g. Kolar, Veligallu and Gadwal) regions at ca. $2700 \mathrm{Ma}$ (Fig. 19b). Melting of down-going slabs at depth, with significant input of continent-derived detritus, produced fluidal hot mafic magmas. Ascent of these hot mafic magmas interacted with, and variably-enriched, the sub-arc mantle, as well as causing melting of both sub-arc mantle and the overlying newly-formed thickened arc crust, leading to generation of the magmatic precursors to the transitional TTGs between 2670-2600 Ma (Fig. 19c). These magmas were emplaced beneath ancient crust in the Central block and newly-formed oceanic arc crust in the Eastern block (Fig. 19d). Emplacement of these transitional TTG magmas caused hot metamorphism of the ancient crust in the Central block close to UHT conditions at $2620 \mathrm{Ma}$ (Jayananda et al., 2011a). Continued subduction led to assembly of the Western, Central and Eastern blocks and eventual slab breakoff led to upwelling of hot asthenosphere, causing widespread low-degree melting of enriched mantle producing hot sanukitoid magmas between 2570-2520 Ma (Fig. 19e). These hot magmas were emplaced into already hot ancient and young juvenile arc crust, causing extensive crustal melting that is consistent with horizontal contractional flow of hot crust on a hot weaker mantle, with orogenic plateau formation, subdued topography and strong seismic reflectivity (Mandal et al., 2018). This is also consistent with tectonic fabric analysis that shows lateral contractional flow of hot orogenic crust up to the Chitradurga boundary shear zone between 2565-2500 Ma and 3D mass distribution through longitudinal flow accommodating the juvenile materials added to the crust during the Neoarchean hot orogen (Chardon et al., 2011).

The hot juvenile magmas induced melting of both ancient and newly-formed juvenile crust (transitional TTGs) and generated anatectic magmas (Jayananda et al., 2000, 2018) corresponding to biotite granites (Dey et al., 2018; Moyen et al.,2013). Crystallization of voluminous mantle-derived sanukitoid magmas in deep crustal magma chambers resulted in the development of shrinkage fractures at mantle depths due to volume loss, which in turn caused low degree decompression melting of highly-enriched sub-arc mantle, producing low viscosity enriched mafic magmas that were rapidly injected into crystallizing magma chambers where their interaction led to mixing and mingling of magmas and formation of MME or fragmented 
syn-plutonic mafic dykes depending on the crystallinity state of the host magma (Jayananda et al., 2009, 2014). Continued heat and fluid flow associated with mantle upwelling also induced low pressure, high to ultra-high temperature metamorphism and final cratonization of Archean crust between 2510-2480 Ma (Peucat et al., 1993, 2013; Jayananda et al., 2013a).

\section{Conclusions}

The integrated field, petrological, zircon U-Pb and in situ Lu-Hf, elemental and whole rock Nd isotope data presented here from a wide crustal corridor in the Central and Eastern Dharwar Craton define episodic continental growth leading to craton formation, wherein the gneisses and granitoids form markers recording this transition and fingerprinting a shift in geodynamic processes through the Archean. The major conclusions arising from this study are as follows:

1. Zircon $\mathrm{U}-\mathrm{Pb}$ ages, together with in situ $\mathrm{Lu}-\mathrm{Hf}$ isotopes and whole-rock $\mathrm{Sm}-\mathrm{Nd}$ isotope data, reveal multi-stage crustal growth in the Central and Eastern blocks of the Dharwar Craton at ca. 3360-3200 Ma, 3000-2960 Ma, 2700-2600 Ma and 2570-2520 Ma.

2. A major outburst of juvenile felsic crustal addition at ca. 2670-2600 Ma is represented by transitional TTG, followed at $2570-2520 \mathrm{Ma}$ by calc-alkaline magmatism of sanukitoid affinity, which contributed to peak continental growth. The preceding ca. 2750-2700 Ma greenstone volcanism originated from depleted to chondritic mantle reservoirs and contributed to an earlier episode of significant crustal growth.

3. Elemental data, in situ $\mathrm{Hf}$ isotope, and whole rock $\mathrm{Nd}$ isotope data indicate that the magmatic precursors of the transitional TTGs formed by melting of composite sources involving dominantly chondritic mantle and mafic arc crust, whereas the sanukitoids with syn-plutonic mafic dykes originated from chondritic to enriched mantle with or without minor crustal input. Anatectic granites were generated by reworking of ancient and newly formed juvenile crust.

4. The documented west to east age zonation, structural patterns, petrological, elemental and isotope data, together with seismic reflection data, suggest westward convergence of hot oceanic lithosphere leading to assembly of micro-blocks. Continued convergence with eventual slab break-off led to asthenosphere upwelling that induced widespread mantle melting and juvenile magmatic additions, resulting from lateral flow of ductile hot crust on hot weaker mantle and leading to formation of orogenic plateaux with subdued topography, as indicated by strain fabric data and strong seismic reflectivity in the Eastern Dharwar Craton. 
5. Juvenile calc-alkaline magmatism was spatially linked to extensive crustal reworking, high-temperature/low-pressure metamorphism and final cratonization in the late Neoarchean.

\section{Acknowledgements}

We thank Prof. T. Tsunoge, handling editor and two anonymous referees for their constructive comments which helped in improving the quality of our manuscript. M. Jayananda gratefully acknowledges funding support from the DST transect program (ESS/16/334/2008), continued by the UGC (F-42-72/2013(SR and DST-FIST [SR/FST/ESI146/2016(C)] program. Kowete-u Sekhamo acknowledges CSIR for a Fellowship and K.R. Aadhiseshan acknowledges UGC for funding support. M Kusiak acknowledges support from the European Commission Marie Curie Program of the EU (PIOF-GA-2010-273412). We also gratefully acknowledge Prof. R.C. Patel, Kurukshetra University, and the John de Laeter Centre at Curtin University in Perth for providing facilities for crushing and zircon separation. Dr V. Balaram and Dr. M. Satyanarayanan are thanked for their support in trace element analysis. D. Chardon, J-F Moyen, J-J Peucat, H. Martin and T. Kano were involved in discussions on the geology of the Dharwar Craton over many years. M. Guitreau acknowledges support from Région Auvergne, LabEx ClerVolc (ANR-10-LABX-0006), and the French Research Agency (project Zircontinents; ANR-17-CE31-0021).

\section{References}

Anand, R., Balakrishnan, S., 2010. Pb, Sr and Nd isotope systematics of metavolcanic rocks of the Hutti greenstone belt, Eastern Dharwar craton: constraints on age, duration of volcanism and evolution of mantle sources during Late Archean. J. Asian Earth Sci. 39, $1-11$.

Anand, R., Balakrishnan, S., Kooijman, E., Mezger, K., 2014. Neoarchean crustal growth by accretionary processes: evidence from combined zircon-titanite $\mathrm{U}-\mathrm{Pb}$ isotope studies on granitoid rocks around the Hutti greenstone belt, eastern Dharwar Craton, India. J. Asian Earth Sci. 79, 72-85. 
Armstrong, R.L., Harmon, R.S., 1981. Radiogenic isotopes: the case for crustal recycling on a near-steady-state no-continental-growth earth [and discussion]. Philos. Trans. R. Soc. Lond. Ser. A: Math. Phys. Sci. 301, 443-472.

Balakrishnan, S., and Rajamani, V., 1987. Geochemistry and petrogenesis of granitoids around the Kolar Schist Belt, south India: Constraints for the evolution of the crust in the Kolar area: The Journal of Geology, v. 95, p. 219-240. doi:10.1086/629121.

Balakrishnan, S., Hanson, G.N., Rajamani, V., 1990. Pb and Nd isotope constraints on the origin of high $\mathrm{Mg}$ and tholeiitic amphibolites, Kolar schist belt, south India. Contributions to Mineralogy and Petrology 107, 279-292.

Balakrishnan, S., Rajamani, V., Hanson, G.N., 1999. U-Pb ages for zircon and titanite from the Ramagiri area, southern India: evidence for accretionary origin of the eastern Dharwar Craton during the late Archean. Journal of Geology 107, 69-86.

Barker, F., 1979. Trondhjemite: definition, environment and hypothesis of origin. In: Barker, F. (Ed.), Trondhjemites, Dacites and Related Rocks. Elsevier, Amsterdam, pp. 1-12.

Barker, F., Arth, J.G., 1976. Generation of trondhjemite-tonalite liquids and Archean bimodal trondhjemite-basalt suites. Geology 4, 596-600.

Bédard, J.H., 2006. A catalytic delamination-driven model for coupled genesis of Archaean crust and sub-continental lithospheric mantle. Geochimica et Cosmochimica Acta 70, 1188-1214.

Bedard, J.H., 2013. How many arcs can dance on the head of a plume? A 'Comment' on: A critical assessment of Neoarchean 'plume only' geodynamics: Evidence from the Superior province, by Derek Wyman, PR, 2013. Precambrian Research 229, 189-197.

Bedard, J.H., 2018. Stagnant lids and mantle overturns: Implications for Archean tectonics, magma genesis, crustal growth, mantle evolution and the start of plate tectonics. Geoscience Frontiers 9, 19-49.

Belousova, E.A., Kostitsyn, Y.A., Griffin, W.L., Begg, G.C., O’Reilly, S.Y., Pearson, N.J., 2010. The growth of the continental crust: constraints from zircon Hf-isotope data. Lithos $119,457-466$.

Bhaskar Rao, Y.J., Janardhan, A.S., Vijaya Kumar, T., Narayana, B.L., Dayal, A.M., Taylor, P.N., Chetty, T.R.K., 2003. Sm-Nd model ages and Rb-Sr isotopic systematics of charnockite gneisses across the Cauvery shear zone, south India: implication for Archean, Neoproterozoic terrane boundary in the granulite terrane. In: Ramakrishnan, M. (Ed.), Tectonics of the Southern Granulite Terrane. vol. 50. Kuppam-Palani Geotransect: Geological Society of India Memoir, 297-317.

Bidyananda, M., Gerdes, A., and Goswami, J.N., 2016. U-Pb and Hf isotope records in detrital and magmatic zircon from eastern and western Dharwar craton, southern India: Evidence for coeval Archean crustal evolution, Precambrian Research, 275, 496-512.

Bidyananda, M., Goswami, J.N., Srinivasan, R., 2011. Pb-Pb zircon ages of Archaean metasediments and gneisses from the Dharwar craton, southern India: implications for the antiquity of the eastern Dharwar craton. Journal of Earth System Science 120, 643-661.

Black, L.P. et al., 2003. TEMORA 1: a new zircon standard for Phanerozoic U-Pb geochronology. Chemical Geology, 200(1-2): 155-170. Blackwell Scientific Publications, Palo Alto, CA, United States, 312 pp. 
Borah, K., Rai, S. S., Gupta, S., Prakasam, K. S., Kumar, S. and Sivaram, K., 2014. Preserved and modified mid-Archean crustal blocks in Dharwar Craton: seismological evidence. Precambrian Research 246, 16-34.

Bouhallier, H., Chardon, D., Choukroune, P., 1995. Strain patterns in Archaean dome and basin structures: the Dharwar craton (Karnataka, South India). Earth Planet. Sci. Lett. $135,57-75$.

Bouhallier, H., Choukroune, P., Ballèvre, M., 1993. Diapirism, bulk homogeneous shortening and transcurrent shearing in the Archaean Dharwar craton: the Holenarsipur area, southern India. Precambrian Research 63, 43-58.

Brown, M., Johnson, T., 2018. Secular change in metamorphism and onset of plate tectonics. American mineralogist 103, 181-196.

Cawood, P.A., Hawkesworth, C.J., Dhuime, B., 2013. The continental record and the generation of continenetal crust. GSA Bulletin 125 (1-2), 14-32.

Cawood, P.A., Hawkesworth, C.J., Pisarevsky, S.A., Dhuime, B., Captanio, F.A., Nebel, O., 2018. Geological archive of the onset of plate tectonics. Phil. Trans. Royal Soc. A 376:20170405.

Chadwick, B., Ramakrishnan, M., Viswanatha, M.N., 1981. Structural and metamorphic relations between Sargur and Dharwar supracrustal rocks and peninsular gneiss in central Karnataka. Journal of the Geological Society of India 22, 557-569.

Chadwick, B., Ramakrishnan, M. and Viswanatha, M.N., 1985. Bababudan - A Late Archaean intracratonic volcanosedimentary basin, Kamataka, South India. Part I: Stratigraphy and Basin Development. Jour. Geol. Soc. India 26, 769-801.

Chadwick, B., Vasudev, V., Hegde, G.V., Nutman, A.P., 2007. Structure and SHRIMP U-Pb zircon ages of granites adjacent to the Chitradurga schist belt: implications for Neoarchean convergence in the Dharwar craton, southern India. J. Geol. Soc. India 69, 524.

Chadwick, B., Vasudev, V.N., Hedge, G.V., 2000. The Dharwar craton, southern India, interpreted as the result of late Archaean oblique convergence. Precambrian Res. 99, 91101. http://dx.doi.org/10.1016/S0301-9268 (99) 00055-8.

Champion, D.C., Smithies, R.H., 2003b. Slab melts and related processes-Archaean versus recent. In: Arima, M., Nakajima, T., Ishihara, S. (Eds.), Hutton Symposium V, The Origin of Granites and Related Rocks. Geological Survey of Japan. pp. 19.

Chardon, D., Choukroune, P., Jayananda, M., 1996. Strain patterns, de'collement and incipient sagducted greenstone terrains in the Archaean Dharwar craton (south India). J. Struct. Geol. 18, 991-1004.

Chardon, D., Choukroune, P., Jayananda, M., 1998. Sinking of the Dharwar basin (South India): implications for Archaean tectonics. Precambrian Research 91, 15-39.

Chardon, D., D. Gapais, and F. Cagnard 2009. Flow of ultrahot orogens: A view from the Precambrian, clues for the Phanerozoic, Tectonophysics, 477, 105-118, doi:10.1016/j.tecto.2009.03.008.

Chardon, D., Jayananda, M., 2008. A 3D field perspective on deformation, flow and growth of the lower continental crust. Tectonics 27http://dx.doi.org/10.1029/2007 TC002120. (TC1014). 
Chardon, D., Jayananda, M., Chetty, T.R.K., Peucat, J.-J., 2008. Precambrian continental strain and shear zone patterns: the South Indian case. J. Geophys. Res. 113, B08402. http://dx.doi.org/10.1029/2007JB005299.

Chardon, D., Jayananda, M., Peucat, J.-J., 2011. Lateral contrictional flow of hot orogenic crust: insights from the Neoarchean of South India, geological and geophysical implications for orogenic plateaux. Geochem. Geophys. Geosyst. 12http://dx.doi.org/10.1029/ 2010GC003398. (Q02005).

Chardon, D., Peucat, J.J., Jayananda, M., Choukroune, P., Fanning, C.M., 2002. Archean granite-greenstone tectonics at Kolar (South India): interplay of diapirism and bulk inhomogeneous contraction during juvenile magmatic accretion. Tectonics 21 (3). http://dx.doi.org/10.1029/2001TC901032.

Chauvel, C., Goldstein, S.L., Hofman, A.W., 1995. Hydration and dehydration of oceanic crust controls $\mathrm{Pb}$ evolution in the mantle. Chemical Geology, 126, 65-75.

Choukroune, P., Ludden, J.N., Chardon, D., Calvert, A.J., Bouhallier, H., 1997. Archaean crustal growth and processes: a comparision of the Superior province and the Dharwar craton India. In: Burg, J.P., Ford, M. (Eds.), Orogeny Through Time, Geological Society Special Publication 121, 63-98.

Condie, K.C., 2000. Episodic continental growth models: afterthoughts and extensions. Tectonophysics, 322, 153-162.

Condie, K.C., 2014. Growth of continental crust: a balance between preservation and recycling. Mineral. Mag. 78, 623-637.

Condie, K.C., and Aster, R.C., 2010. Episodic zircon age spectra of orogenic granitoids: the supercontinent connection and crustal growth. Precambrian Research 180, 227-236.

Condie, K.C., Arndt, N., Davalle, A., Puetz, J., 2017. Zircon age peaks: Production or preservation of continental crust?. Geosphere, 13, 2, doi.10.1130/GESO1361.1

Corfu, F. 2003. Extraction of $\mathrm{Pb}$ with artificially too-old ages during stepwise dissolution experiments on Archean zircon. Lithos, 53, 279-291. https://doi.org/ 10.1016/S00244937(00)00030-X.

Davidson, J., Macpherson, C., Turner, S., 2007. Amphibole control in the differentiation of arc magmas. Geochim. Cosmochim. Acta 71, A204.

Defant, M.J., Drummond, M.S., 1990. Derivation of some modern arc magmas by melting of young subducted lithosphere. Nature 347, 662-665.

Dey, S., 2013. Evolution of Archean crust in the Dharwar craton: The Nd isotope record. Precambrian Research 227, 227-246.

Dey, S., Halla, J., Kurhila, M., Nandy, J., Heilimo, E., Pal, S., 2016. Geochronology of Neoarchean granitoids of the NW eastern Dharwar craton; Implications for crust formation. In: Halla, J., Whitehouse, M.J., Ahmad, T., Bangal, Z (Eds). Crust - Mantle interactions and Granitoid diversification: Insights from Archean cratons. Geological Society of London Special Publications, 449. http://doi.org/10.1144/SP449.9.

Dey, S., Nandy, J., Choudhary, A.K., Liu, Y., and Zong, K., 2015. Neoarchean crustal growth by combined arc-plume action: evidence from the Kadiri Greenstone Belt, eastern Dharwar craton, India. Geological Society of London, Special Publications 389, pp. 135163. 
Dey, S., Nandy, J., Choudhary, A.K., liu, Y., Zong, K., 2014. Origin and evolution of granitoids associated with the Kadiri greenstone belt, eastern Dharwar craton: a history of orogenic to anarogenic magmatism. Precambrian Research, 246, 64-90.

Dey, S., Pal, S., Balakrishnan, S., Halla, J., Kurhila, M., Heilimo, E. 2018. Both plume and arc: origin of Neoarchaean crust as recorded in Veligallu greenstone belt Dharwar craton, India. Precambrian Research, 314, 41-61, https://doi.org/10.1016/j.precamres.2018.04.019

Dey, S., Pandey, U.K., Rai, A.K., Chaki, A., 2012. Geochemical and $\mathrm{Nd}$ isotope constraints on petrogenesis of granitoids from NW part of the eastern Dharwar craton: possible implications for late Archaean crustal accretion. Journal of Asian Earth Sciences 45, 40-56.

Dhuime, B., Hawkesworth, C.J., Cawood, P.A., Storey, C.D., 2012. A change in the geodynamics of continental growth 3 billion years ago. Science 335, 1334-1336.

Dhuime, B., Hawkesworth, C.J., Delavault, H., Caood, P., 2018. Rates of generation and destruction of the continental crust: implications for continental growth. Phil. Trans. R. Soc. A 376: 20170403.

Feng, R., Kerrich, R., 1992. Geochemical evolution of granitoids from Archean Abitiibi southern volcanic zone and the Pontiac sub-province, Superior province, Canada. Implications for tectonic history and source regions. Chemical Geology, 98, 23-70.

Foley, S., Teipolo, M., Vannucci, R., 2002. Growth of early continental crust controlled by subduction zones. Nature, 417, 837-840.

Friend, C. R. L., and A. P. Nutman., 1991, SHRIMP U-Pb geochronology of the Closepet granite and Peninsular gneisses, Karnataka, South of India, Journal Geological Society of India 38, 357-368.

Gerya, T., 2014. Precambrian geodynamics: concepts and models. Gondwana Research, v. 25, pp. 442-463. http://dx.doi.org/10.1016/j.gr.2012.11.008.

Gireesh, R.V., Kowete-u Sekhamo and Jayananda, M., 2012. Anatomy of 2.57-2.52 Ga granitoids plutons in the eastern Dharwar craton, southern India: Implications for magma chamber processes. Episodes 35-3, 398-413.

Goodwin, A.M., 1996. Principles of Precambrian Geology. London, Acedemic press, p.327.

Griffin, W.L., Pearson, N.J., Belousova, E., Jackson, S.E., van Achterbergh, E., O'Reilly, S.Y., Shee, S.R., 2000. The Hf isotope composition of cratonic mantle: LAM-MCICPMS analysis of zircon megacrysts in kimberlites. Geochim. Cosmochim. Acta 64, $133-147$.

Griffin, W.L., Wang, X., Jackson, S.E., Pearson, N.J., O'Reilly, S.Y., Xu, X., Zhou, X., 2002. Zircon chemistry and magma mixing, SE China: in-situ analysis of Hf isotopes, Tonglu and Pingtan igneous complexes. Lithos 61, 237-269.

Griffin, W.L., Pearson, N.J., Belousova, E.A., Saeed, A., 2006. Comment: Hf isotope heterogeneity in zircon 91500. Chemical Geology 233, 358-363.

Guitreau, M., Mukusa, S.B., Loudin, L., and Krishnan, S., 2017, New constraints on early formation of western Dharwar craton (India) from igneous zircon $\mathrm{U}-\mathrm{Pb}$ and $\mathrm{Lu}-\mathrm{Hf}$ isotopes. Precambrian Research 302, 33-49.

Gupta, S., Rai, S.S., Prakasam, K.S., Srinagesh, D., Bansal, B.K., Chadha, R.K., Priestley, K., and Gaur, K., 2003. The nature of the crust in southern India: implications for 
Precambrian crustal evolution. Geophysical Research Letters, v. 30. http://dx.doi.org/10.1029/2002GL016770.

Halla, J., 2005. Late Archean high-mg granitoids (sanukitoids) in the Southern Karelian craton, Eastern Finland. Lithos 79, 161-178.

Harish Kumar, S.B., Jayananda, M., Kano, T., Shadakshara Swamy, N., Mahabaleshwar, B., 2003. Late Archean juvenile accretion process in the Eastern Dharwar Craton; KuppamKarimangala area. Mem. Geol. Soc. India 50, 375-408.

Hawkesworth, C., Cawood, P., Dhuime, B., 2013. Continental growth and the crustal record. Tectonophysics 609, 651-660.

Hawkesworth, C.J., Dhuime, B., Pietranik, A.B., Cawood, P.A., Kemp, A.I.S., Storey, C.D., 2010. The generation and evolution of the continental crust. J. Geol. Soc. 167, 229-248.

Heilimo, E., Halla, J., Holtta, P. 2010. Discrimination and origin of the sanukitoid series: geochemical constraints from the Neoarchaean western Karelian Province (Finland). Lithos, 115, 27- 39 .

Hoffmann, J.E., Munker, C., Næraa, T., Rosing, M.T., Herwartz, D., Garbe-Schonberg, D., Svahnberg, H., 2011. Mechanisms of Archean crust formation inferred from highprecision HFSE systematics in TTGs.Geochim et CosmochimActa, 75, 4157-4178.

Hokada, T., Horie, K., Satish-Kumar, M., Ueno, Y., Nasheeth, A., Mishima, K., Shiraishi K 2013. An appraisal of Archaean supracrustal sequences in Chitradurga Schist Belt, Western Dharwar Craton, Southern India. Precambrian Research, 227, 99-119 http://dx.doi.org/10.1016 /j.precamres.2012.04.006. In: U.S. Geol. Surv. Prof. Pap. 525 (B), 79-84.

Iswar Kumar, C., Santosh, M., Wilde, S.A., Tsunogae, T., Itaya, T., Windley, B.F. Sajeev, K., 2016. Mesoproterozoic suturing of Archean crustal blocks in western peninsular India: Implications for India-Madagascar correlations. Lithos, 263, 143-160.

Jayananda, M., Mahabaleswar, B., 1991. Relationship between shear zones and igneous activity: the Closepet granite of southern India. Proc. Indian Acad. Sci. (Earth Planet. Sci.) $100,31-36$.

Jayananda, M., Peucat, J.-J., 1996. Geochronological framework of southern India. In: Santosh, M., Yoshida, M. (Eds.), Archaean and Proterozoic Terranes in Southern India. Gondwana Research Group Memoir 3. Field Science Publishers, Osaka, pp. 52-73.

Jayananda, M, Banerjee, M., Pant, N.C., Dasgupta, S., Kano, T., Mahesha, N., Mahableswar, B. 2011. 2.62 Ga high-temperature metamorphism in the central part of the Eastern Dharwar Craton: implications for late Achaean tectonothermal history. Geological Journal 46: doi:10.1002/gj.1308.

Jayananda, M, Peucat, J-J., Chardon, D., Krishna Rao, B and Corfu, F., 2013b Neoarchean greenstone volcanism, Dharwar craton, Southern India: Constraints from SIMS zircon geochronology and Nd isotopes. Precambrian Research, 227, 55-76, doi.org/10.1016/ j.precamres.2012.05.002.

Jayananda, M., Martin G., Tarun Thomas, T., Martin, H., Aadhiseshan, K.R., Gireesh, R.V., Peucat, J-J., Satyanarayanan, M., 2019. Geochronology and geochemistry of Meso- to Neoarchean magmatic epidote-bearing potassic granites, western Dharwar Craton (Bellur-Nagamangala-Pandavpura corridor), southern India: implications for the successive stages of crustal reworking and cratonization. In. Dey, S. \& Moyen, J.-F. 
(eds.) Archean Granitoids of India: Windows into Early Earth Tectonics. Geological Society, London, Special Publications, 489. https://doi.org/10.1144/SP489-2018-125.

Jayananda, M., Chardon, D., Peucat, -J.-J., and Fanning, C.M., 2015. Paleo- to Mesoarchean TTG accretion and continental growth, western Dharwar craton, southern India: SHRIMP $\mathrm{U}-\mathrm{Pb}$ zircon geochronology, whole-rock geochemistry and $\mathrm{Nd}-\mathrm{Sr}$ isotopes: Precambrian Research 268, 295-322. doi:10.1016/j.precamres.2015.07.015

Jayananda, M., Chardon, D., Peucat, J-J., Capdevila, R., 2006. 2.61 Ga potassic granites and crustal reworking in the western Dharwar craton, southern India: Tectonic, geochronologic and geochemical constraints. Precambrian Research 150, 1-26.

Jayananda, M., Gireesh, R.V., Kowete-u Sekhamo and Miyazaki, T. 2014. Coeval Felsic and Mafic Magmas in Neoarchean Calc-alkaline Magmatic Arcs, Dharwar Craton, Southern India: Field and Petrographic Evidence from Mafic to Hybrid Magmatic Enclaves and Synplutonic Mafic Dykes. Journal Geological Society of India, 84, 5-28.

Jayananda, M., Kano, T., Peucat, J-J., Channabasappa, S., 2008. 3.35 Ga komatiite volcanism in the western Dharwar craton: constraints from $\mathrm{Nd}$ isotopes and whole rock geochemistry. Precambrian Research 162, 160-179. doi:10.1016/j.precamres. 2007.07.010 Elsevier.

Jayananda, M., Martin, H., Peucat, J.-J. \& Mahabaleswar, B. 1995. Late Archaean crustmantle interactions: geochemistry of LREE-enriched mantle derived magmas. Example of the Closepet batholith, southern India. Contributions to Mineralogy and Petrology, 119, 314-329.

Jayananda, M., Miyazaki, T., Gireesh, R.V., Mahesha, N and Kano, T. 2009. Synplutonic mafic dykes from late Archaean granitoids in the Eastern Dharwar Craton, Southern India. Jour. Geol. Soc. India 73, 117-130.

Jayananda, M., Moyen, J.F., Martin, H., Peucat, J.J., Auvray, B., Mahabaleswar, B. 2000. Late Archean (2550-2520) juvenile magmatism in the Eastern Dharwar Craton, southern India: constraints from geochronology, $\mathrm{Nd}-\mathrm{Sr}$ isotopes and whole rock geochemistry. Precambrian Research, 99, 225-254.

Jayananda, M., Santosh, M., and Aadhiseshan, K.R., 2018. Formation of Archean (3600-2500 Ma) continental crust in the Dharwar craton, southern India. Earth Science Reviews 181, $12-42$.

Jayananda, M., Tsutsumi, Y., Miyazaki, T., Gireesh, R.V., Kowe -u Kapfo, Tushipokla, Hidaka, H., Kano, 2013a. Geochronological constraints on Meso-neoarchean regional metamorphism and magmatism in the Dharwar craton, southern India. Journal of Asian Earth Sciences, 78, 18-38, doi.org/ 10.1016/j.jseaes. 2013.04.033.

Jenner, G.A., Foley, S.F., Jackson, S.E., Green, B.J., Fryer, H.P., Longerich, H.P., 1994. Determination of partition coefficients for trace elements in high pressure-temperature run products by laser ablation microprobe-inductively coupled plasma mass spectrometry (LAM-ICP-MS). Geochim. Cosmochim. Acta58, 5099-5103.

Johnson, T.E., Kirkland, C.L., Gardiner, N.J., Brown, M., Smithies, R.H., Santosh, M., 2019. Secular change in TTG compositions: Implications for the evolution of Archaean geodynamics. Earth and Planetary Science Letters, 505, 65-75.

Kamber, B.S., 2015. The evolving nature of terrestrial crust from the Hadean, through the Archaean, into the Proterozoic. Precambrian Research 258, 48-82. 
Kamber, B.S., Ewart, A., Collerson, K.D., Bruce, M.C., McDonald, G.D., 2002. Fluid-mobile trace element constraints on the role of slab melting and implications for Archaean crustal growth models. Contributions to Mineralogy and Petrology 144, 38-56.

Kerrich, R., Manikyamba, C., 2012.Contemporaneous eruption of Nb-enriched basaltsKadakites-Na-adakites from the 2.7 Ga Penakacherla terrane: implications for subduction zone processes and crustal growth in the eastern Dharwar craton, India. Canadian Journal of Earth Sciences 49, 615-636.

Khanna, T.C., Sesha Sai, V.V., Bizimis, M., Krishna, A.K. 2016.Petrogenesis of ultramafics in the Neoarchean Veligallu greenstone terrane, eastern Dharwar craton, India: Constraints from bulk-rock geochemistry and Lu-Hf isotopes. Precambrian Research, $285,186-201$.

Khanna, T.C., Bizimis, M., Yogodzinski, G.M., Mallick, S., 2014. Hafnium-neodymium isotope systematics of the $2.7 \mathrm{Ga}$ Gadwal greenstone terrane, Eastern Dharwar craton, India: Implications for the evolution of the Archean depleted mantle. Geochimica et Cosmochimica Acta 127, 10-24.

Kinny, P.D., 1997. Users Guide to U-Th-Pb Dating of Titanite, Perovskite, Monaziteand Baddeleyite. Curtin University, School of Physics, Perth, Australia, pp. 21.

Klemme, S., Blundy, J.D., Wood, B.J., 2002. Experimental constraints on major and trace element partitioning during partial melting of eclogite. Geochim. Cosmochim. Acta 66, 3109-3123.

Komiya, T., Maruyama, S., 2007. A very hydrous mantle under the western Pacific region. Implications for formation of marginal basins and style of Archean tectonics. Gondwana Research, 11, 132-147.

Korenaga J. 2018 Crustal evolution and mantle dynamics through Earth history. Phil. Trans. R. Soc. A 376: 20170408. http://dx.doi.org/10.1098/rsta.2017.0408.

Krogstad EJ, Balakrishnan S, Mukhopadhyay DK, Rajamani V, Hanson GN 1989. Plate tectonics 2.5 billion years ago: evidence at Kolar, south India. Science 243: 1337-1340.

Krogstad, E.J, Hanson, G.N. and Rajamani, V., 1991. U-Pb ages of zircon and sphene for two gneiss terrains adjacent to the Kolar Schist Belt, south India: Evidence for separate crustal evolution histories. Journal of Geology, 99, 801-816.

Kumar, A., Bhaskar Rao, Y.J., Sivaraman, T.V., Gopalan, K., 1996. Sm-Nd ages of Archaean metavolcanic of the Dharwar craton, South India. Precambrian Research 80, 206-215.

La Flèche, M.R., Camiré, G., Jenner, G.A., 1998. Geochemistry of post-Acadian, Carboniferous continental intraplate basalts from the Maritimes Basin, Magdalen Islands, Quebéc, Canada. Chem. Geol. 148, 115-136.

Lancaster, P.J., Dey S., Storey, C.D., Mitra, A.M., Bhunia, R.K., 2015. Contrasting crustal evolution processes in the Dharwar craton: Insights from detritalzircon $\mathrm{U}-\mathrm{Pb}$ and $\mathrm{Hf}$ isotopes. Gondwana Research, 28, 1361-1372. http://dx.doi.org/10.1016/j.gr. 2014.10.010.

Laurent, O., Martin, H., Moyen, J.-F., Doucelance, R., 2014. The diversity and evolution of late-Archean granitoids: evidence for the onset of "modern-style"plate tectonics between 3.0 and 2.5 Ga. Lithos 205, 208-235. 
Li, S.S., Santosh, M., Palin, R.M., 2018a. Metamorphism during the Archeanpaleoproterozoic transition associated with micro-block amalgamation in the Dharwar craton, India. Journal of Petrology 59 (12), 2435-2462.

Li, S.S., Santosh, M., Ganguly, S., Thanooja, P.V., Sajeev, K., Pahari, A., et al., 2018b. Neoarchean microblock amalgamation in southern India: evidence from the nallamalai suture zone. Precambrian Research. S030192681830127X.

Lobach-Zhuchenko, S.B., Rollinson, H., Chekulaev, V.P., Savatenkov, V.M., Kovalenko, A.V., Martin, H., Guseva, N.S., and Arestova, N.A., 2008. Petrology of a Late Archean, highly Potassic, Sanukitoid Pluton from the Baltic Shield: Insights into Late Archean Mantle Metasomatism. Journal of Petrology 49-3, 393-420.

Ludwig, K.R. 2008. User's Manual for Isoplot 3.6. A Geochronological Toolkit for Microsoft Excel. Berkeley Geochronology Center Special Publication, 4.

Mahabaleshwar B, Jayananda M, Peucat J-J, and Shadakshara Swamy, N., 1995. Archaean high-grade gneiss complex from Satnur-Halagur-Sivasamudram areas, Karnataka, southern India: Petrogenesis and crustal evolution; Journal Geological Society of India, 45, 33-49.

Mandal, B., Vijaya Rao, V., Sarkar, D., Bhaskar Rao, Y.J., Raju, S., Karuppannan, P., and Sen, M.K., 2018. Deep crustal seismic reflection images from the Dharwar craton, Southern India - evidence for the Neoarchean subduction. Geophysical Journal International, v. 212, pp. 777-794.

Manikyamba, C., Ganguly, S., Santosh, M., Saha, A., Chatterjee, A., Khelen, A.C., 2015b. Neoarchean arc-juvenile back-arc magmatism in eastern Dharwar Craton, India: geochemical fingerprints from the basalts of Kadiri greenstone belt. Precambrian Research 258, 1-23.

Manikyamba, C., Ganguly, S., Santosh, M., Subramanyam, K.S.V., 2017. Volcanosedimentary and metallogenic records of the Dharwar greenstone terranes, India: Window to Archean plate tectonics, continent growth, and mineral endowment. Gondwana Rsearch, http://dx.doi.org/10.1016/j.gr.2017.06.005.

Manikyamba, C., Ganuly, S., Santosh, M., Rajanikanth Singh, R., Saha, Abhishek, 2014. Arc-nascent back-arc signature in metabasalts from the Neoarchaean Jonnagiri greenstone terrane, Eastern Dharwar Craton, India. Geological Journal, DOI: 10.1002/gj.2581.

Manikyamba, C., Kerrich, R., 2012. Eastern Dharwar Craton, India: continental lithosphere growth by accretion of diverse plume and arc terranes. Geoscience Frontiers 3, 225-240.

Manikyamba, C., Kerrich, R., Khanna, T.C., Krishna, A.K., Satyanarayanan, M., 2008. Geochemical systematics of komatiit-tholeiite and adakite-arc basalt associations: the role of a mantle plume and convergent margin in formation of the Sandur Superterrane, Dharwar Craton, India. Lithos 106, 155-172.

Manikyamba, C., Kerrich, R., Khanna, T.C., Satyanarayanan, M., Krishna, A.K., 2009. Enriched and depleted arc basalts, with high-Mg andesites and adakites: a potential paired arc-backarc of the $2.7 \mathrm{Ga}$ Hutti greenstone terrane, India. Geochimica et Cosmochimica Acta $73,1711-1736$.

Manikyamba, C., Kerrich, R., Naqvi, S.M., Ram Mohan, M., 2004. Geochemical systematics tholeiitic basalts from the 2.7 Ga Ramagiri- Hungund composite greenstone belt, Dharwar Craton. Precambrian Research 134, 21-39. 
Manikyamba, C., Kerrich, R., Polat, A., Raju, K., Satyanarayanan, M., Krishna, A.K., 2012. Arc picrite-potassic adakitic-shoshonitic volcanic association of the Neoarchean Sigegudda Greenstone Terrane, Western Dharwar Craton: transition from arc wedge to lithosphere melting. Precambrian Res. 212, 207-224.

Martin, H., 1986. Effect of steeper Archean geothermal gradient on geochemistry of subduction-zone magmas. Geology 14, 753-756.

Martin, H., Moyen, J-F and Rapp, R. 2010. The sanukitoid series: magmatism at the Archean-Proterozoic transition Transactions of the Royal Society of Edinburgh, 100, pp. $15-33$.

Martin, H., Moyen, J-F., Guitreau, M., Blichert-Toft, J., Le Pennac, J.C., 2014. Why Archean TTGs cannot be generated by melting of MORB melting in subduction zone. Lithos, 198199, 1-13. http://dx.doi.org/10.1016/j.lithos.2014.02.017.

Martin, H., Smithies, R.H., Rapp, R., Moyen, J.-F., Champion, D., 2005. An overview of adakite, tonalite-trondhjemite-granodiorite (TTG), and sanukitoid: relationships and some implications for crustal evolution. Lithos 79, 1-24.

Masuda, A., Nakamura, N., and Tanaka, T., 1973. Fine structure of mutually normalized rareearth patterns of chondrites: Geochimica et Cosmochimica Acta 37, 239-248. doi:10.1016/0016-7037(73)90131-2.

Maya, J.M., Bhutani, R., Balakrishnan, S., and Rajee Sandhya, S., 2017. Petrogenesis of 3.15 Ga old Banasandra komatiites from the Dharwar craton, India: Implications for early mantle heterogeneity. Geoscience Frontiers 8, 467-481.

Mohan, M.R., Piercey, S.J., Kamber, B.S. And Sarma, S.D. 2013. Subduction related tectonic evolution of the Neoarchean eastern Dharwar Craton, southern India: New geochemical and isotopic constraints. Precambrian Research, 227, 204-226.

Mohan, M.R., Sarma, D.S., Mc Naughton, N.J., Fletcher, I.R., Wilde, S.A., Siddiqui, M.H., Rasmussen, B., Krapez, B., Gregory, C.J., Kamo,S.L., 2014. SHRIMP zircon and titanite $\mathrm{U}-\mathrm{Pb}$ ages, Lu-Hf isotope signatures and geochemical constraints for $2.56 \mathrm{Ga}$ granite magmatism in western Dharwar craton, southern India: Evidence for short-lived Neoarchean episodic crustal growth. Precambrian Research, 243: 197-220.

Mojzsis, S.J., Devaraju, T.C., Newton, R.C., 2003. Ion microprobe U-Pb age determinations on zircon from the late Archean granulite facies transition zone of Southern India. Journal of Geology 111 (4), 407-425.

Moyen, J.F., 2000. Late-Archean Granitic Magmatism: Example of the Dharwar Craton southern India (Closepet Granite and Related Intrusions). Universite de Blais- Pascal, Clermont Ferrand, France (Ph.D. Thesis).

Moyen, J.-F., 2011. The composite Archaean grey gneisses: petrological significance, and evidence for a non-unique tectonic setting for Archaean crustal growth. Lithos 123, 2136.

Moyen, J.-F., Martin, H., Jayananda, M., Auvray, B., Mahabaleswar, B., 2003a. Late Archean granites: a typology based on the Dharwar Craton (India). Precambrian Research $127,103-123$.

Moyen, J.-F., Nedelec, A., Martin, H., Jayananda, M., 2003b. Syntectonic granite emplacement at different structural levels: the Closepet granite, South India. J. Struct.Geol. 25, 611-631. 
Moyen, J-F., Laurent, O., 2018. Archaean tectonic systems: A view from igneous rocks. Lithos, 302-303, 99-125.

Moyen, J-F., Stevens, G., Kisters A., 2006. Record of mid-Archaean subduction from metamorphism in the Barberton terrain, South Africa. Nature, 442, 559-562.

Mueller, P.A., Wooden, J.L., Mogk, D.W., Henry, D.J., Bowes, D.R., 2010. Rapid growth of an Archean continent by arc magmatism. Precambrian Research, 183, 70- 88 doi:10.1016/j.precamres.2010.07.013.

Nagel, T.J., Hoffmann, J.E., Munker, C., 2012. Generation of Eoarchean tonalitetrondhjemite-granodiorite series from thickened mafic crust. Geology, 40, 375-378.

Naqvi, S.M., Manikyamba, C., Rao, G., Subba Rao, D.V., Ram Mohan, M., Sarma, S., 2002. Geochemical and isotopic constraints on Neoarchean fossil plumes for the formation of volcanic rocks of Sandur Greenstone Belt, India. Journal of the Geological Society of India 60, 27-56.

Nasdala, L., Hofmeister, W., Norberg, N., Mattinson, J.M., Corfu, F., Dorr, W., Kamo, S.L, Kennedy, A.K., 2008. Zircon M257 - a Homogeneous Natural Reference Material for the Ion Microprobe U-Pb Analysis of Zircon. Geostandards and Geoanalytical Research 32, 247-265.

Nasheeth, A., Okudaira, T., Horie, K., Hokada, T., and Satish Kumar, M., 2015. SHRIMP U$\mathrm{Pb}$ zircon ages of granitoids adjacent of Chitradurga shear zone, Dharwar craton, South India and its tectonic implications. Journal of Mineralogical and Petrological Sciences 110, 224-234.

Nasheeth, A., Okudaira, T., Horie, K., Hokada, T., and Satish Kumar, M., 2016. U-Pb SHRIMP Ages of Detrital Zircons from Hiriyur Formation in Chitradurga Greenstone Belt and its Implication to the Neoarchean Evolution of Dharwar Craton, South India. Journal of Geological Society of India 87, 43-54.

Nutman, A.P., Chadwick, B., Krishna Rao, B., Vasudev, V.N., 1996. SHRIMP U/Pb zircon ages of acid volcanic rocks in the Chitradurga and Sandur groups, and granites adjacent to the Sandur Schist belt, Karnataka. Journal of the Geological Society of India 47, 153-164.

Nutman, A.P., Chadwick, B., Ramakrishnan, M., Viswanatha, M.N., 1992. SHRIMP U-Pb ages of detrital zircon in Sargur supracrustal rocks in western Karnataka, southern India. Journal of the Geological Society of India 39, 367-374.

O'Connor, J.T., 1965. A classification for quartz-rich igneous rocks based on feldspar ratios.

Oliveira, M.A., Dall'Agnol, R.,Almedeida, J.A.C., 2011. Petrology of the Mesoarchean Rio Maria suite and descrimintation of sanukitoid series. Lithos, 127, 192-209.

Paces, J.B., Miller, J.D., JR., 1993. Precise U-Pb ages of Duluth Complex and related mafic intrusions, Northeastern Minnesota: geochronological insights to physical, petrogenetic, paleomagnetic, and tectonomagmatic processes associated with the 1.1 Ga Midcontinent Rift System. Journal of Geophysical Research, 98, 13997-14013. https:// doi.org/10. 1029/ 93JB01159.

Pandey, A., Chalapathi Rao., N.V., Chakrabarti, R., Pankaj, P., Pandit, D., Pandey, R., Sahoo, S., 2018. Post-collisional calc-alkaline lamprophyre from Kadiri greenstone belt: Evidence for the Neoarchean convergence related evolution of Eastern Dharwar Craton and its schist belts. Lithos, 320-321; 105-117. 
Peucat, J.-J., Mahabaleswar, M., Jayananda, M., 1993. Age of younger tonalitic magmatism and granulite metamorphism in the amphibolite-granulite transition zone of southern India (Krishnagiri area): comparison with older peninsular gneisses of Gorur- Hassan area. Journal of Metamorphic Geology 11, 879-888.

Peucat, J.-J., Vidal, P., Bernard-Griffiths, J., Condie, K.C.J, 1989. Sr, Nd and Pb isotope systematics in the Archaean low to high grade transition zone of southern India. Synaccretion vs post-accretion granulites. J. Geol. 97, 537-550.

Peucat, J-J., Bouhallier, H., Fanning, C.M., Jayananda, M., 1995. Age of Holenarsipur schist belt, relationships with the surrounding gneisses (Karnataka, south India). Journal of Geology 103, 701-710.

Peucat, J-J., Jayananda, M. Chardon, D., Capdevila, R., Fanning Marc. C., Paquette, JeanLouis., 2013. The lower crust of Dharwar craton, south India: Patchwork of Archean granulitic domains. Precambrian Research, 227, 4-29 http://dx.doi.org/10.1016/ j.precamres.2012.06.009.

Polat, A, 2012, Growth of Archean continental crust in oceanic island arcs. Geology 40, 383384.

Polat, A., Hoffmann, A.W., 2003. Alteration and geochemical patterns of 3.7-3.8 Ga Isua greenstone belt, West Greenland, Precambrian Research, 126, 197-218.

Prabhakar, B.C., Jayananda, M., Shareef, M., Kano, T., 2009. Synplutonic mafic injections into crystallizing granite pluton in the northern part of the eastern Dharwar craton: implications for the magma chamber processes. J. Geol. Soc. India 74, 171-188.

Prouteau, G., Scaillet, Pichavant, M., Maury, R.C., 2001. Evidence for mantle metasomatism by hydrous silicate melts derived from subducted oceanic crust. Nature, 410, 197-200.

Ramakrishnan, M., Viswanatha, M.N., Swami Nath, J., 1976. Basement-cover relationships of Peninsular Gneisses with high grade schists and greenstone belts of southern Karnataka. J. Geol. Soc. India 17, 97-111.

Rapp, R. P., Shimizu, N., Norman, M. D., Applegate, G. S. 1999. Reaction between slabderived melts and peridotite in the mantle wedge: experimental constraints at 3-8 GPa. Chemical Geology 160, 335-56.

Rapp, R.P., Shimizu, N., Norman, M.D., 2003. Growth of early continental crust by partial melting of eclogite. Nature 425, 605-609.

Ratheesh Kumar, R.T., Santosh, M., Yang, Q-Y, Iswar Kumar, C., Chen, N.S., Sajeev, K., 2016. Archean tectonics and crustal evolution of the BIligiri Rangan Block, Southern India. Precambrian Research, 275, 406-428.

Ravi Kumar, M., Arun Singh, Bhaskar Rao, Y.J., Srijayanthi, G., Satyanarayana, H.V., and Sarkar, D., 2018, Vestiges of Precambrian subduction in the south Indian shield? - A seismological perspective. Tectonophysics 740-741, 27-41.

Reymer, A., Schubert, G., 1984. Phanerozoic addition rates to the continental crust and crustal growth. Tectonics 3, 63-77.

Roberts, N.M.W and Santosh, M., 2018. Capturing the Mesoarchean Emergence of Continental Crust in the Coorg Block, Southern India. Geophysical Research Letters 10.1029/2018GL078114.

Roberts, N.M.W. \& Spencer, C.J. 2014. The zircon archive of continent formation through time. In: Roberts, N.M.W., Vankranendonk, M., Parman, S., Shirey, S. \& CLIFT, P.D. 
(eds) Continent Formation Through Time. Geological Society, London, Special Publications, 389,197-225,https://doi.org/10.1144/SP389.14

Rogers, A.J., Kolb, J., Meyer, F.M. and Armstrong, R.A. 2007. Tectono-magmatic evolution of the Hutti-Maski Greenstone Belt, India: Constrained using geochemical and geochronological data. Journal of Asian Earth Sciences 31, 55-70.

Rollinson, H.R., Windley, B.F., Ramakrishnan, M. 1981. Contrasting high and intermediate pressures of metamorphism in the Archaean Sargur Schists of southern India. Contributions to Mineralogy and Petrology 76, 420-429.

Russel, J., Chadwick, B., Krishna Rao, B., Vasudev, V.N., 1996. Whole rock $\mathrm{Pb} / \mathrm{Pb}$ isotopic ages of late Archean limestones, Karnataka, India. Precambrian Res. 78, 261-272.

Sajona, F.G., Maury, R.C., Pubellier, M., Leterrier, J., Bellon, H., Cotton, J., 2000. Magmatic source enrichment by slab derived melts in a young post-collision setting, Central Mindanao (Philippines), Lithos, 54, 173-206.

Santosh, M., Yang, Q-Y., Shaji, E., Ram Mohan, M., Tsunogae, T., Satyanarayanan, M., 2016. Oldest rocks from Peninsular India: Evidence for Hadean to Neoarchean crustal evolution. Gondwana Research. http://dx.doi.org/10.1016/j.gr.2014.11.003.

Santosh, M., and Shan-Shan Li, 2018, Anorthosites from an Archean continental arc in the Dharwar craton, southern India: Implications for terrane assembly and cratonization. Precambrian Research, 308, 126-147.

Santosh, M., Jayananda, M., and Mahabaleswar, B., 1991, Fluid evolution in the Closepet granite: a magmatic source for $\mathrm{CO} 2$ in charnockite formation at Kabbaldurga. Journal Geological Society of India 38, 55-65.

Santosh, M., Yang, Q-Y., Shaji, E., Tsunogae, T., Ram Mohan, M., Satyanarayanan, M., 2015. An exotic Mesoarchean microcontinent: The Coorg Block, southern India. Gondwana Research, 27, 165-195.

Sarma, D.S., McNaughton, N.J., Belusova, E., Ram Mohan, M., Fletcher, I.R., 2012. Detrital zircon U-Pb ages and Hf-isotope systematics from the Gadag Greenstone Belt: Archean crustal growth in the western Dharwar Craton, India. Gondwana Res. 22, 843-854.

Sarvothaman, H., 2001. Archaean high-Mg granitoids of mantle origin in the Eastern Dharwar Craton of Andhra Pradesh. Journal of the Geological Society of India 58, 261268.

Shimoda, G., Tatsumi, Y., Nohda, S., lshizaka, K., Jahn, B.M., 1998. Setouchi high-Mg andesites revisited; geochemical evidence for melting of subducting sediments. Earth Planet. Sci. Lett. 160, 479-492.

Shirey, S.B., Hanson, G.N., 1984. Mantle-derived Archaean monzodiorites and trachyandesites. Nature 310, 222-224.

Sizova, E., Gerya, T. and Brown, M, 2014. Contrasting styles of Phanerozoic and Precambrian continental collision. Gondwana Research 25, 522-545.

Sizova, E., Gerya, T., Stüwe, K., Brown, M., 2015. Generation of felsic crust in the Archean: a geodynamic modeling perspective. Precambrian Research 71, 198-224.

Slama, J., Kosler, J. et al. 2008. Plešovice zircon - a new natural reference material for U-Pb and $\mathrm{Hf}$ isotopic microanalysis. Chemical Geology, 249, 1-35, https://doi.org/10.1016/ j.chemgeo.2007.11.005. 
Smithies, R.H., 2000. The Archaean tonalite-trondhjemite-granodiorite (TTG) series is not an analogue of Cenozoic adakite: Earth and Planetary Science Letters 182, 115-125, doi:10.1016/S0012-821X(00)00236-3.

Smithies R.H., Champion D.C., and Cassidy K.F., 2003. Formation of Earth's Archaean continental crust. Precambrian Research, 127, 89-101.

Smithies, R.H., Champion, D.C., Van Kranendonk, M.J., Howard, H.M., Hickman, A.H., 2005. Modern-style subduction processes in the Mesoarchean geochemical evidence from the 3.12 Ga Whundo intra-oceanic arc. Earth and Planetary Science Letters 231 (3-4), 221-237.Smithies, R.H., Champion, D.C., Van Kranendonk, M.J., 2009. Formation of Paleoarchean continental crust through infracrustal melting of enriched basalt. Earth Planetary Science Letters, 281, 298-306.

Smithies, R.H., Champion, R.H., 2000. The Archean high-Mg diorite suite: Links to tonalitetrondhjemite-granodiorite magmatism and implications for early Archean crustal growth. Journal of Petrology, 41, 1653-1671.

Söderlund, Ulf, Patchett, P., Jonathan, Vervoort, J., Isachsen, Clark. 2004. The 176Lu decay constant determined by $\mathrm{Lu}-\mathrm{Hf}$ and $\mathrm{U}-\mathrm{Pb}$ isotope systematics of Precambrian mafic intrusions. Earth and Planetary Science Letters. 219. 311-324. 10.1016/S0012$821 \mathrm{X}(04) 00012-3$.

Soderlund, U., Bleeker, W., Demirer, K., Srivastava, R.K., Hamilton, M., Nilsson, M., Pesonen, L.J., Samal, A.M., Jayananda, M., Ernst, R., Srinivas, M., 2018. Emplacement ages of Paleoproterozoic mafic dyke swarms in eastern Dharwar craton, India: Implications for paleoreconstructions and support for a $\sim 30^{\circ}$ change in dyke trends from south to north. Precambrian Research, https://doi.org/10.1016/j.precamres.2018.12.017

Spencer, C.J., Roberts, N.M.W., Santosh, M., 2017. Growth, destruction, and preservation of Earth's continental crust. Earth-Science Reviews 172, 87-106.

Srinivasan, R., Ojakangas, R.W., 1986. Sedimentology of quartz-pebble conglomerates and quartzites of the Archaean Bababudan Group, Dharwar Craton, South India: evidence for early crustal stablity. J. Geol. 94, 199214.

Srivastava, R.K., M. Jayananda, Gulab C. Gautama, V. Gireesh, Amiya K. Samal 2014a. Geochemistry of an ENE-WSW to NE-SW trending 2.37 Ga mafic dyke swarm of the eastern Dharwar craton, India: Does it represent a single magmatic event?.

Stacey, J.S., Kramers, J.D., 1975. Approximation of terrestrial lead isotope evolution by a two-stage model. Earth and Planetary Science Letters, 26(2): 207-221.

Stern, R.A., 2001. A new isotopic and trace-element standard for the ion microprobe: preliminary thermal ionization mass spectrometry (TIMS) U-Pb and electron-microprobe data. Geological Survey Canada: 2016.

Stern, R.A., Bodorkos, S., Kamo, S.L., Hickman, A.H., Corfu, F., 2009. Measurement of SIMS instrumental mass fractionation of $\mathrm{Pb}$ isotopes during zircon dating. Geostandards and Geoanalytical Research, 33(2): 145-168.

Sun, S.-S., McDonough, W.F., 1989. Chemical and isotopic systematics of oceanic basalts: implications for mantle composition and processes. In: Saunders, A.D., Norry, M.J. (Eds.), Magmatism in the Ocean Basins. 42. Geological Society of London Special Publication, pp. 313-345. 
Swami Nath, J., Ramakrishnan, M. (Eds.), 1981. Early Precambrian Supracrustals of Southern Karnataka. Geological Survey of India, Memoir 112, p. 350.

Swami Nath, J., Ramakrishnan, M. \& Viswanatha, M.N. 1976. Dharwar stratigraphic model and Karnataka craton evolution. Records of the Geological Survey of India, 107, 149175 .

Tatsumi, Y., 2006. High-Mg andesites in Setouchi volcanic belt. Southwestern Japan: analogy to Archean magmatism and continental crust formation. Annual Reviews of Earth and Planetary Sciences, 34, 467-499.

Taylor, S.R., Gordon, M.P., 1977. Geochemical application of spark source mass spectrography. III. Element sensitivity, precision and accuracy. Geochimica Cosmochimica. Acta 41, 1375-1380.

Taylor, S.R., McLennan, S.M., 1995. The geochemical evolution of the continental crust. Rev. Geophys. 33, 241-265, http://dx.doi.org/10.1029/95RG00262

Thebaud, N., Rey, P.F., 2013. Archean gravity driven tectonics on hot and flooded continents, Controls on long-lived mineralized hydrothermal systems away from the continental margins. Precambrian Research, 229, 93-104.

Van Achterbergh, E., Ryan, C.G., Jckson, S.E. \& Griffin, W.L. 2001. Data reduction software for LA-ICP-MS: appendix. In: Sylvester P.J. (ed.) Laser Ablation - ICP-Mass Spectrometry in the Earth Sciences: Principles and Applications. Mineralogical Association of Canada (MAC) Short Course Series, 29, 239-243.

Venkata Dasu, S.P., Ramakrishnana, M., Mahabaleswar, B., 1991. Sargur-Dharwar relationship around the Komatiite-rich Jayachamarajapura greenstone belt in Karnataka. J. Geol. Soc. India 38, 577-592.

Vijaya Rao, V., Murty, A.S.N., Dipankar Sarkar, Bhaskar Rao, Y.J., Prakash Khare, Prasad, A.S.S.S.R.S., Sridher, V., Raju, S., Rao, G.S.P., Karuppannan, Prem Kumar, N., and Mrinal K. Sen, 2015. Crustal velocity structure of the Neoarchean convergence zone between the eastern and western blocks of Dharwar Craton, India from seismic wideangle studies, Precambrian Research 266, 282-295.

Wang, J.Y., Santosh, M., 2019. Eoarchean to Mesoarchean crustal evolution in the Dharwar craton, India. Evidence from detrital zircon U-Pb and Hf isotopes. Gondwana Research, $72,1-14$.

Wang, Y., Zang, Y., Zhao, G., Fan, W., Xia, X., Zhang, F., Zhang, A., 2009. Zircon U-Pb geochronological and geochemical constraints on the petrogenesis of the Taishan sanukitoids (Shandong): Implications for Neoarchean subduction in the Eastern block, North China Craton. Precambrian Research, 174, 273-286.

Wu, F.-Y., Yang, Y.-H., Xie, L.-W., Yang, J.-H., Xu, P., 2006. Hf isotopic compositions of the standard zircons and baddeleyites used in $\mathrm{U}-\mathrm{Pb}$ geochronology. Chem. Geol. 234, 105-126.

Wiedenbeck, M., Alle, P. et al., 1995. Three natural zircon standards for U-Th-Pb, Lu-Hf, trace element and REE analyses. Geostandard Newsletters, 19, 1-23, https://doi.org/10.1111/j.1751-908X.1995.tb00147.x

Williams, I.S., 1998. U-Th-Pb geochronology by ion microprobe. In: McKibben, M.A., Shanks III, W.C., Ridley, W.I. (Eds.), Applications of Micro analytical Techniques to Understanding Mineralizing Processes 7, 1-35. 
Wyman, D.A., 2018. Do cratons preserve evidence of stagnant lid tectonics? Geoscience Frontiers, 9, 3-17.

Xiong, X.L., Han, J.W., Wu, J.H., 2007. Phase equilibrium and trace element partitioning between minerals and melt in the metabasalt system: constraints on the formation conditions of TTG/adakite magmas and the growth of early continental crust. Earth Sci. Frontiers 14, 151-158.

Yang, J.-H., Chung, S.-L., Zhai, M.-G., Zhou, X.-H., 2004. Geochemical and Sr-Nd-Pb isotopic compositions of mafic dikes from the Jiaodong Peninsula, China: evidence for vein-plus-peridotite melting in the lithospheric mantle. Lithos 73, 145-160.

Yang, Q.Y., and Santosh, M., 2015. Zircon U-Pb geochronology and Lu-Hf isotopes from the Kolar greenstone belt, Dharwar craton, India: Implications for crustal evolution in an ocean-trench-continental transect. Journal of Asian Earth Sciences 113 (2), 797-811.

Zacharaiah. J.K., Hanson, G.N., Rajamani, V., 1995. Post-crystallization disturbance in the neodymium and lead isotope systems of metabasalts from Ramagiri schist belt in southern India. Geochimica et Cosmochemica Acta, 59: 3189-3203.

Zacharaiah. J.K., Rajamani, V., Hanson, G.N., 1997. Petrogenesis and source characteristics of meta-tholeiites from the Archean Ramagiri schist belt, eastern part of Dharwar craton, India. Contribution to Mineralogy and Petrology 129, 87-104.

Zachariah J.K., Mohanta MK, Rajamani V., 1996a. Accretionary evolution of the Ramagiri Schist Belt, eastern Dharwar craton. J Geol Soc India 47: 279-291.

Zhou, Y., Zhao, T., Zhai, M., Gao, J., Sun., Sun., Q., 2014. Petrogenesis of the Archean tonalite-trondhjemite-granodiorite (TTG) and granites in the Lushan area, southern margin of the North China craton: Implications for crustal accretion and transformation. Precambrian Research, 255, 514-537. 


\section{Figure captions}

Fig. 1. Geological sketch map of the Dharwar Craton showing the three crustal blocks with strain fabrics and shear zone patterns (modified after Chardon et al., 2008, 2011; Peucat et al.,2013; Jayananda et al., 2013a).

Fig.2. Geological sketch map of the NW-SE crustal corridor (Hanagal - Madnapalle) displaying the different gneisses, greenstone sequences and granitoid plutons present in the area (modified after Chardon et al., 2011; Peucat et al. 2013).

Fig.3. Representative field photographs of lithologies in the Central block: (a) Migmatitic gneiss in an abandoned quarry at the $46 \mathrm{~km}$ marker stone along the Challakere -Bellary road (near telecom tower). (b) Melt-filled shear zone traversing metapelite undergoing melting where large sillimanite crystals are rimmed by spinel-quartz. (c) Dark grey flat gneiss along the western boundary of the Closepet batholith near Rolla village. (d) Dark grey flat gneiss traversed by melt-filled shears, $2 \mathrm{~km}$ east of Palasamudram along the Lepakshi -Kadiri road. (e) Quartz monzonite of the Sira magmatic complex with leucocratic veins extending along a flat magmatic foliation. (f) Coeval quartz monzonite and monzogranite showing diffuse contact with a biotite-rich rim and both cut by a later felsic vein, at $2 \mathrm{~km}$ west of Puttaparthi village. (g) Porphyritic monzogranite with MME at Reddicheruvukatta along the GorantlaKadiri road. (h) Anatectic granite dyke cutting across dark grey gneiss along the western boundary of the Closepet batholith (10 km south of Hangal). (i) Anatectic granite containing large angular remnants of mafic lower crust along the shear zone at the western margin of the Closepet batholith, about $1 \mathrm{~km}$ south of Kundurpi village. (j) Syn-plutonic mafic dyke defining magmatic flow in anatectic granite, about $8 \mathrm{~km}$ north of Madakasira along the Pavagada road.

Fig.4. Representative field photographs of lithologies in the Eastern block: (a) Banded dark grey transitional TTG gneiss at about $3 \mathrm{~km}$ west of Vepuraka railway station. (b) Diatexitic gneiss $3 \mathrm{~km}$ north of Horsely Hills Cross along the Madanapalle - Kadiri road. (c) Large quarry displaying interlayered dark grey banded transitional TTG, porphyritic monzogranite and diatexite, 5-km north of Madanapalle along the Kadiri road. (d) Dark grey monzodiorite with MME, $1 \mathrm{~km}$ north of Billur along the Bagepalli road. (e) Diatexitic gneisses together with quartz-monzonite define magmatic flow with biotite-rich rim along the contact $(4 \mathrm{~km}$ marker stone along the Gollapalli-Mudivedu road). (f) Fresh exposure displaying magma mingling with hybrid enclaves forming pillow-like structures $(1 \mathrm{~km}$ south of Tanakallu along the Madanapalle-Kadiri road).

Fig. 5. Interpretative cross-section of the studied corridor from Hangal to Madanapalle showing lithological associations and fabrics.

Fig. 6. Photomicrographs of representative mineral assemblages from the Central block (crossed polars). (a) Quartz-plagioclase-K-feldspar-biotite assemblage in older migmatitic gneiss from the western boundary of the Closepet batholith (exposure near telecom tower). (b) Quartz-plagioclase-K-feldspar- hornblende-biotite in dark grey banded gneiss at Ravadi quarry (c) Quartz monzonite with quartz-plagioclase-K-feldspar-clinopyroxene-hornblendebiotite from Pavagada town quarry. (d) Monzogranite showing quartz-plagioclase-Kfeldspar-hornblende-biotite from $2 \mathrm{~km}$ west of Puttaparthi village. (e) Syn-plutonic dyke from Madakasira showing quartz-plagioclase-K-feldspar-clinopyroxene-hornblende-biotite. (f) 
Anatectic granite showing bimodal quartz-K-feldspar-biotite at about $3 \mathrm{~km}$ SE of Pavagada along the Hindupur road. Mineral abbreviations: Kfl- K-feldspar, Plg-plagioclase, Cpxclinopyroxene, Qtz-quartz; Bt, Bio-biotite. Amp -Amphibole.

Fig. 7. Photomicrographs of representative mineral assemblages from the Eastern block: (a) Dark grey banded gneiss from $2 \mathrm{~km}$ west of Vepuraka, showing quartz-plagioclase-Kfeldspar-hornblende-biotite. (b) Quartz monzonite from the eastern margin of the Kadiri greenstone belt showing quartz-plagioclase-K-feldspar-hornblende-biotite. (c) Syn-plutonic dyke (near Tanakallu) showing quartz-plagioclase-K-feldspar-hornblende-biotite. (d) QuartzK-feldspar-biotite in anatectic granite from Horsley Hills.

Fig. 8.1a-8.1d - U-Pb concordia diagrams of migmatitic TTG and dark grey banded gneisses from the Central block. CL images of representative analysed grains are also provided in the figures. 8.1a - U-Pb concordia diagram of zircons analysed from migmatitic TTG (EDC TTG 2b); $8.1 \mathrm{~b}$ - U-Pb concordia diagram of transitional TTGs from sample 17 CL01); 8.1c Zircon U-Pb concordia diagram of dark grey banded gneiss (KO 32); 8.1d - Zircon U-Pb concordia diagram for transitional TTG (KO20). See the text for details.

Fig. 8.2a to $2 \mathrm{f}$. U-Pb concordia diagrams for zircons analysed from sanukitoids, syn-plutonic mafic dyke and anatectic granite from the Central block. CL images of representative analysed zircon grains are also presented in the figures. 8.2a-U-Pb concordia diagram of zirons analysed from sanukitoid (PAV-VES 01a); 8.2b - U-Pb concordia diagram of zircons analysed from sanukitoid (KO18); 8.2c - U-Pb concordia diagram of zircons analysed from sanukitoid (KO19a); 8.2d - U-Pb concordia diagram of zircon analysed from granitoid (KO15); 8.2e - U-Pb concordia diagram of zircon analysed from synplutonic dyke (PAVVES $01 \mathrm{~d}) ; 8.2 \mathrm{f}-\mathrm{U}-\mathrm{Pb}$ concordia diagram of zircon analysed from anatectic granite (KO22). See the text for details.

Fig.8.3a to 3d. U-Pb concordia diagrams for transitional TTGs, sanukitoids and anatectic granite from the eastern block. CL images of representative zircon grains are also provided in the figures. 8.3a - U-Pb Concordia diagram of zircon analysed from transitional TTGs (KO8); 8.3b - U-Pb concordia diagram of zircon analysed from transitional TTGs (KO7); $8.3 \mathrm{c}-\mathrm{U}-\mathrm{Pb}$ concordia diagram of granitoid from sample (KO10); 8.3d - U-Pb concordia diagram of granitoid from sample (KO29a). See the text for details.

Fig. 9 (a). Normative Ab-An-Or triangular diagram (after O'Connor, 1965; updated by Barker, 1979) with fields from Barker (1979); (b). Na-K-Ca triangular plot (after Barker and Arth, 1976) discriminating the calc-alkaline differentiation trend of sanukitoids, anatectic granite from the trondhjemite trend of the TTGs. It also shows the transitional character of the younger transitional TTGs; (c). $\mathrm{Al}_{2} \mathrm{O}_{3} /\left(\mathrm{CaO}+\mathrm{Na}_{2} \mathrm{O}+\mathrm{K}_{2} \mathrm{O}\right.$ mol) versus $\mathrm{K}_{2} \mathrm{O} / \mathrm{Na}_{2} \mathrm{O}$ plot showing the samples plotting in the fields of TTG, sanukitoid and biotite granite; (d). $\mathrm{Al}_{2} \mathrm{O}_{3} /\left(\mathrm{FeO}^{\mathrm{t}}+\mathrm{MgO}\right)$ versus $\mathrm{CaO} /\left(\mathrm{Na}_{2} \mathrm{O}+\mathrm{K}_{2} \mathrm{O}\right)$ plot (after Laurent et al., 2014) showing the transitional character of transitional TTGs with respect to the sanukitoids and biotite-granite.

Fig. 10. Key major element Harker diagrams for transitional TTGs, sanukitoids, anatectic granites, and syn-plutonic dykes.

Fig.11. Chondrite normalized and primitive mantle normalized diagrams for rocks from the Central block. (a) Chondrite normalized REE patterns of transitional TTGs; (b) Primitive mantle normalized multi-element spider diagram (Sun and Mc Donough,1989) of transitional 
TTGs; (c) Chondrite normalized REE patterns of sanukitoids; (d) Primitive mantle normalized multi-element spider diagram of sanukitoids; (e) Chondrite normalized REE patterns of anatectic granites; (f) Primitive mantle normalized spider diagram of anatectic granites; (g) Chondrite normalized REE patterns of group 1 syn-plutonic mafic dykes; (h) Primitive mantle normalized multi-element spider diagram of group 1 syn-plutonic dykes; (i) Chondrite normalized REE patterns of group 2 syn-plutonic dykes; (j) Primitive mantle normalized multi-element spider diagram of group 2 syn-plutonic dykes.

Fig.12. Chondrite normalized and primitive mantle normalized diagrams for rocks from the Eastern block. (a) Chondrite normalized REE patterns of transitional TTGs; (b) Primitive mantle normalized multi-element spider diagram of transitional TTGs; (c) Chondrite normalized REE patterns of sanukitoids; (d) Primitive mantle normalized multi-element spider diagram of sanukitoids; (e) Chondrite normalized REE patterns of anatectic granites; (f) Primitive mantle normalized spider diagram of anatectic granites; (g) Chondrite normalized REE patterns of synplutonic mafic dykes; (h) Primitive mantle normalized multielement spider diagram of syn-plutonic dykes.

Fig.13. (a) Initial ${ }^{176} \mathrm{Hf} /{ }^{177} \mathrm{Hf}$ versus zircon ages plot for the transitional TTGs, sanukitoids syn-plutonic mafic dykes and anatectic granites; (b) $\varepsilon \mathrm{Hf}_{(\mathrm{T})}$ versus zircon ages obtained in this study and from published data (Bidyananda et al., 2016); (c) $\varepsilon \mathrm{Nd}_{(\mathrm{T})}$ versus zircon ages of rocks from the present study and from published data (Krogstad et al., 1995; Peucat et al., 1993; Jayananda et al., 2000; Moyen, 2000; Dey et al., 2014).

Fig. 14. (a) $3^{*} \mathrm{CaO}-\mathrm{Al}_{2} \mathrm{O}_{3} /\left(\mathrm{FeO}^{\mathrm{t}}+\mathrm{MgO}\right)-5^{*}\left(\mathrm{~K}_{2} \mathrm{O} / \mathrm{Na}_{2} \mathrm{O}\right)$ triangular plot (Laurent et al., 2014) depicting the sources of transitional TTGs, sanukitoids, syn-plutonic dykes and anatectic granites; (b) $\mathrm{Sr}+\mathrm{Ba}$ versus $\mathrm{FeO}^{\mathrm{t}}+\mathrm{MgO}$ plot (Laurent et al., 2014) showing enrichment of sources from transitional TTGs to sanukitoids.

Fig.15. (a) Sr/Y versus Y binary plot (after Defant and Drummond, 1990) showing the role of mineral phases in the source residue. (b) $(\mathrm{La} / \mathrm{Yb})_{\mathrm{N}}$ versus $(\mathrm{Yb})_{\mathrm{N}}$ plot (Martin, 1986) characterizing residual garnet or amphibole. The majority of samples plot in the area without residual garnet or with only $7-15 \%$ residual garnet.

Fig. 16. $\mathrm{Nb} / \mathrm{Ta}$ versus $\mathrm{Zr} / \mathrm{Sm}$ plot (Foley et al., 2002) showing residual amphibole and ilmenite in an arc source residue, but without any rutile.

Fig. 17. Summary of zircon age data from this study and published data to highlight Archean crustal evolution in the Central and Eastern Dharwar Craton.

Fig.18. $(\mathrm{Hf} / \mathrm{Sm})_{\mathrm{N}}$ versus $(\mathrm{Ta} / \mathrm{La})_{\mathrm{N}}$ plot (La Flèche et al., 1998) showing dominantly meltrelated enrichment, with minor fluid-related enrichment, of the mantle sources involved in generation of the transitional TTGs, sanukitoids and syn-plutonic dykes.

Fig.19. Model showing westward convergence of hot oceanic lithosphere during the assembly of the micro-blocks. Eventual slab break-off led to asthenosphere upwelling inducing widespread mantle melting resulting in juvenile magmatic additions resulting from lateral flow of ductile hot orogenic crust on hot weaker mantle. This led to 3D mass distribution and formation of orogenic plateaux with subdued topography as indicated by strain fabric data and strong seismic reflectivity along the E-W crustal profile. 
2249

12250

22251

${ }_{4}^{3} 2252$

52253

62254

72255

8 2256

102257

112258

122259

132260

$15^{2261}$

162262

172263

182264

192265

212266

222267

232268

242269

26

27

28

29

30

31

32

33

34

35

36

37

38

39

40

41

42

43

44

45

46

47

48

49

50

51

52

53

54

55

56

57

58

59

60

61

62

63

64

65

\section{Supplementary Data}

Appendix: Analytical methods for zircon U-Pb geochronology

Supplementary table 1. Zircon U-Pb data for the transitional TTGs, sanukitoids, syn-plutonic dykes and anatectic granites.

Supplementary table 2. In situ Hf isotope data for the transitional TTGs, sanukitoids, synplutonic dykes and anatectic granites.

Supplementary table 3. Major and trace element data for transitional TTGs, sanukitoids, synplutonic dykes and anatectic granites.

Supplementary table 4. Results for whole-rock $\mathrm{Sm}-\mathrm{Nd}$ isotope measurements by thermal ionization mass spectrometry (TIMS). 


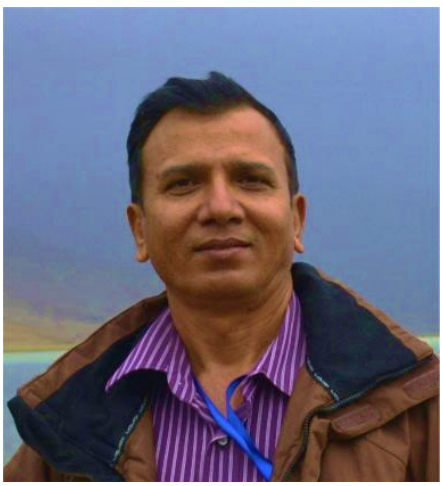

M. Jayananda currently Professor at Centre for Earth, Ocean and Atmospheric Sciences, University of Hyderabad (India). His research interests include early earth dynamics, continental growth, craton formation and shift from anoxic to oxygenated environments. He has more than 100 publications to his credit. In recognition of his research contributions, he was conferred Sir C.V.Raman Young Scientist Award (1999), National Mineral Award (2000) and M.R. Srinivasa Rao Award for Petrology (2000), B. Rama Rao Award (2007), B.P Radhakrishna Prize (2004, 2010) of the Geological Society of India, He has been elected as Fellow of Indian Academy of Sciences and National Academy of Sciences (India). Prof. Jayananda has worked in several laboratories in France and Taiwan as an Invited Professor, Visiting Scientist and JSPS Fellow in Japan. He has participated in international science projects funded by CNRS-INSU, IUGS-IGCP, JSPS and CEFIPRA. He was the Editor-in Chief of the IUGS flagship journal Episodes (2010-2013), currently EditorHimalayan Geology, Editorial Board Member- Precambrian Research, and Journal of Asian Earth Sciences.

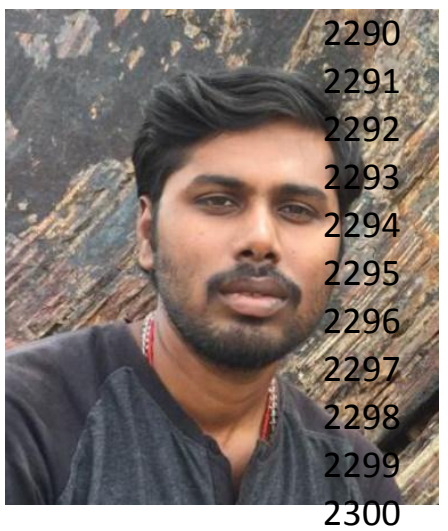

K.R. Aadhiseshan obtained his MSc degree from Bharathidasan University and $\mathrm{PhD}$ from University of Delhi (India). He is focusing research on crustal evolution in the Dharwar craton particularly on the basement rocks across the Chitradurga boundary shear zone addressing accretionary history of the juvenile crust, reworking and cratonization processes including assembly of micro-blocks. He has carried out extensive work on the eastern Dharwar craton focussing on magmatism, continental growth and craton formation. His research interest includes tectonics of the evolving Archean Earth and craton formation.

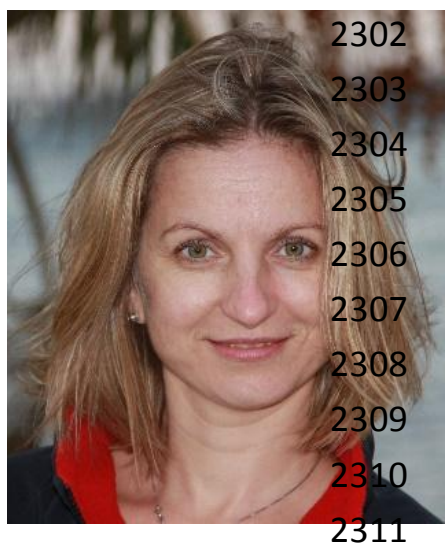

Monika A. KUSIAK is an Associate Professor in the Department of Polar and Marine Sciences of the Institute of Geophysics, Polish Academy of Sciences, in Warsaw. Her research is concentrated on the U-Th-Pb geochronology of accessory minerals (zircon, monazite, xenotime) in evolving magmatic systems and resetting of isotope systematics by metamorphic, hydrothermal and diagenetic processes. Her current investigations focus on applying a variety of isotopic techniques to zircon grains from ancient rocks, mostly obtained from Polar Regions, in order to understand the behavior of elements at the nano- as well as the micro-scale. She is particularly interested in early Earth processes. Monika is an alumni of the Japanese Society for the Promotion of Science, Foundation for Polish Sciences, Marie Skłodowska-Curie Actions and the Alexander von Humboldt Foundation. 


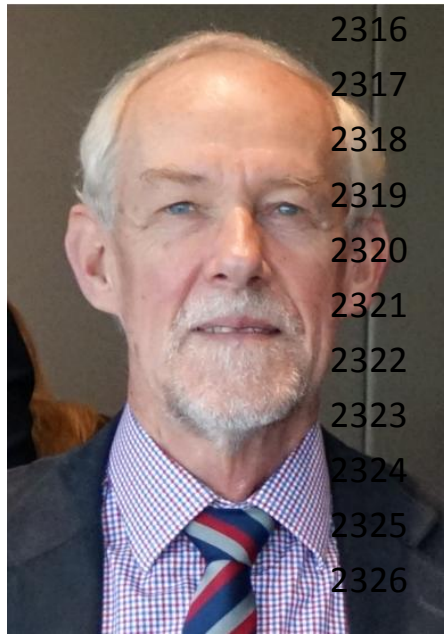

Simon Wilde is Professor of Precambrian Geology and a John Curtin Distinguished Professor at in the School of Earth \& Planetary Sciences at Curtin University in Perth, Western Australia. He applies field investigations, petrology, geochemistry and geochronology to the global study of continental crustal evolution. His main focus in recent years has been the investigation of the scant record of Hadean activity on Earth, comparing this to the earliest crustal rocks preserved on all continents. He also investigates the role of magmatism in the amalgamation and destruction of supercontinents. He is a ThomsonReuters/Clarivate Analytics High-Cited Researcher.

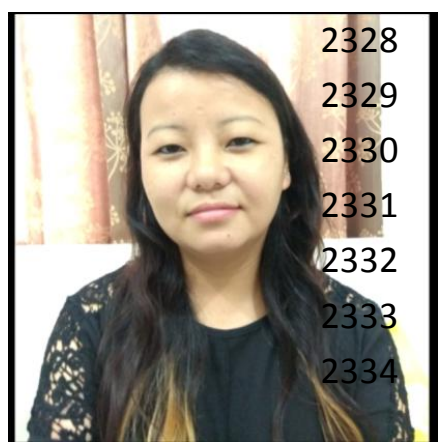

Koweteu Sekhamo is currently working as an Assistant Professor at Patkai Christian College, Dimapur, Nagaland State (India). She has obtained her Master's degree from Bangalore University and $\mathrm{PhD}$ degree from University of Delhi on Neoarchean magmatism in the Eastern Dharwar craton. Her current research interest includes magmatism in different tectonic settings, early earth dynamics and continental growth.

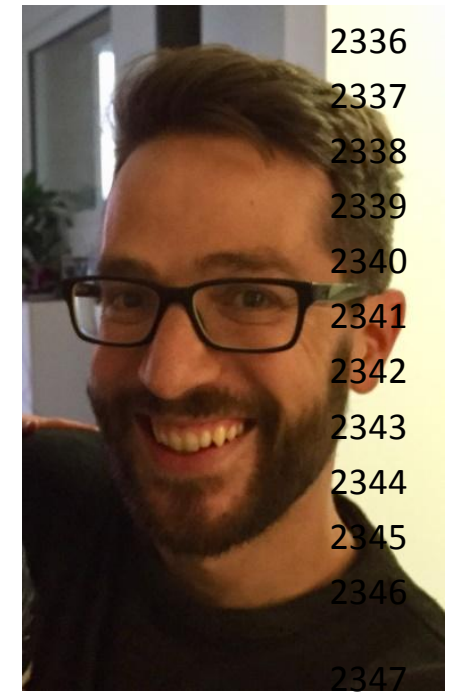

Martin Guitreau is a postdoctoral fellow at Laboratoire Magmas et Volcans of the Université Clermont Auvergne (France). He obtained a $\mathrm{PhD}$ from Ecole Normale Supérieure de Lyon (France) in 2012 after what he conducted postdoctoral research at the University of New Hampshire (USA) from 2012 to 2014, at the University of Manchester (UK) from 2014 to 2015, and at Laboratoire Magmas et Volcans since 2015. He is an isotope geochemist specialized in radiogenic systems such as Lu-Hf and $\mathrm{U}-\mathrm{Pb}$, notably in zircon, but he also integrates geochemistry, petrology, and field work to tackle key questions about Precambrian geology. 
M. Santosh is Professor at the China University of Geosciences Beijing (China), Specially Appointed Foreign Expert of China, Professorial Fellow at the University of Adelaide, Australia and Emeritus Professor at the Faculty of Science, Kochi University, Japan. PhD (Cochin University of Science and Technology, India), D.Sc. (Osaka City University, Japan) and D.Sc. (University of Pretoria, South Africa). He is the Founding Editor of Gondwana Research as well as the founding Secretary

2369 R.V. Gireesh is a geologist in Karnataka state department of 2370 Mines and Geology. He has served as an Assistant Professor 2371 in Suratkal University and Central University of Karnataka. 2372 He has obtained MSc degree from University of Mysore and $2373 \mathrm{PhD}$ from University of Bangalore. He has worked 2374 Neoarchean calc-alkaline magmatism with special focus on 2375 magma chamber dynamics and interaction of coeval felsic and mafic magmas. His interest include magmatism with associated mineralization in different tectonic settings. 


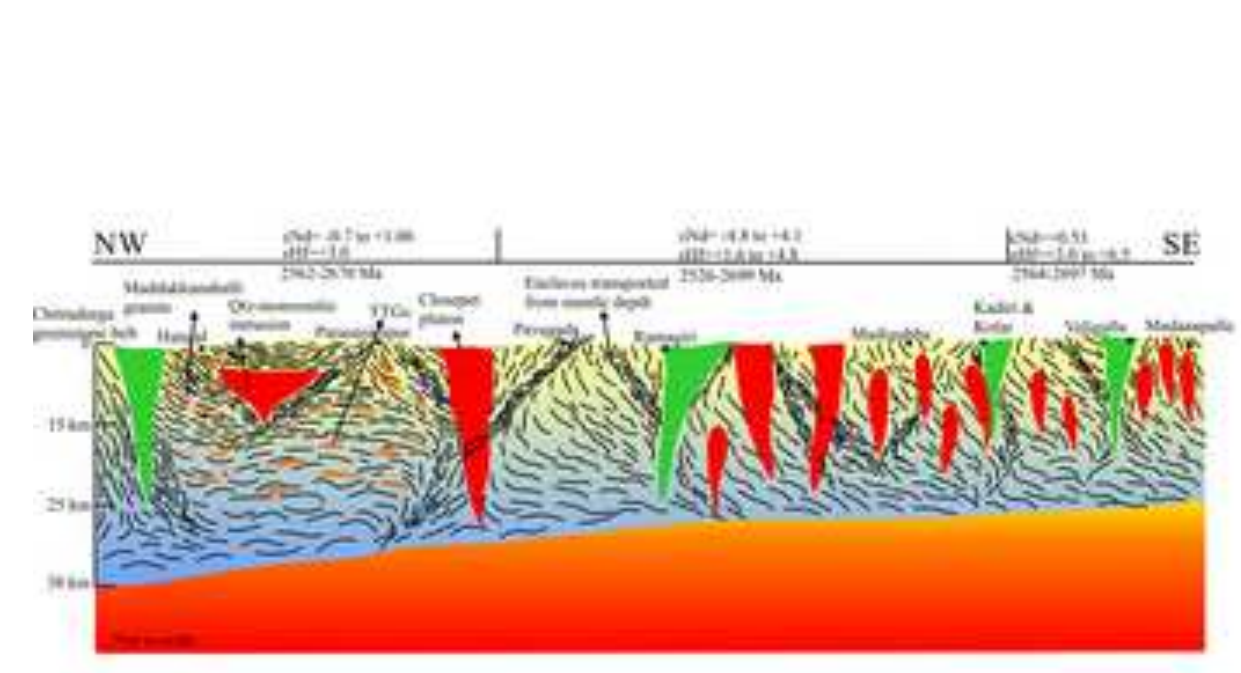

Figure: Interpretative cross-section of the studied corridor.

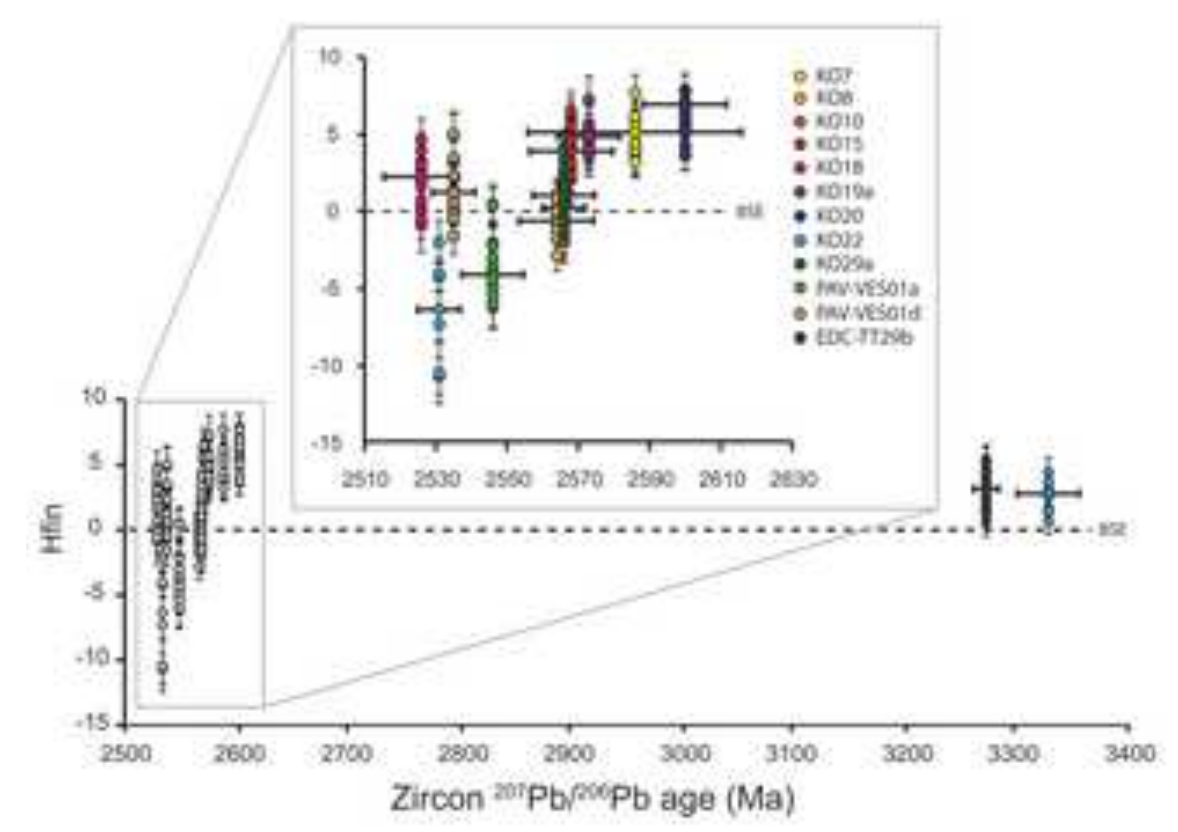

Figure: $\varepsilon H f(t)$ vs zircon ages indicating source mantle and crustal signatures.

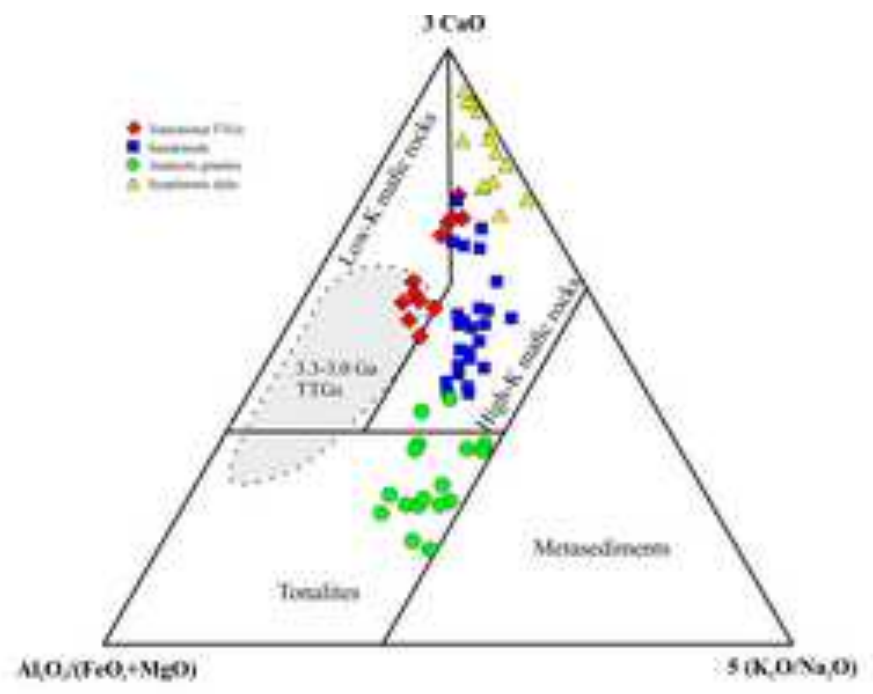

Figure: Ternary diagram (Laurent et al 2014) indicating the source rocks of gneisses and granitoids.

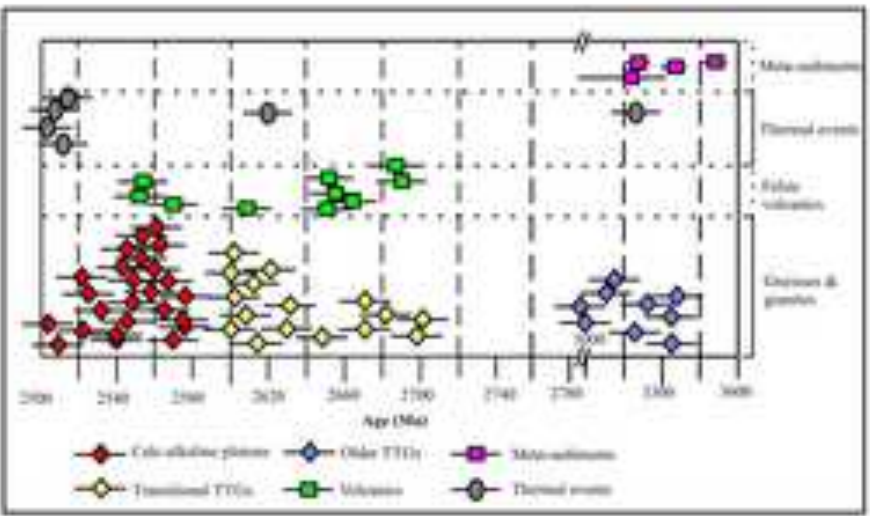

Figure showing multi-stage crustal growth, thermal events and cratonization. 


\section{Research Highlights}

Multi-stage Archean crustal growth ca. 3360-3200 Ma, ca. 3000-2960 Ma, ca. 2700$2600 \mathrm{Ma}$ and ca. 2570-2520 Ma.

Secular changes in the composition of granitoids through Neoarchean suggest increasing involvement of enriched peridotitic mantle.

$>$ Convergence of oceanic lithosphere and eventual slab breakoff lead to asthenosphere upwelling.

Lateral flow of hot orogenic crust lead to orogenic plateau formation with subdued topography. 


\section{Figure}

Click here to download high resolution image

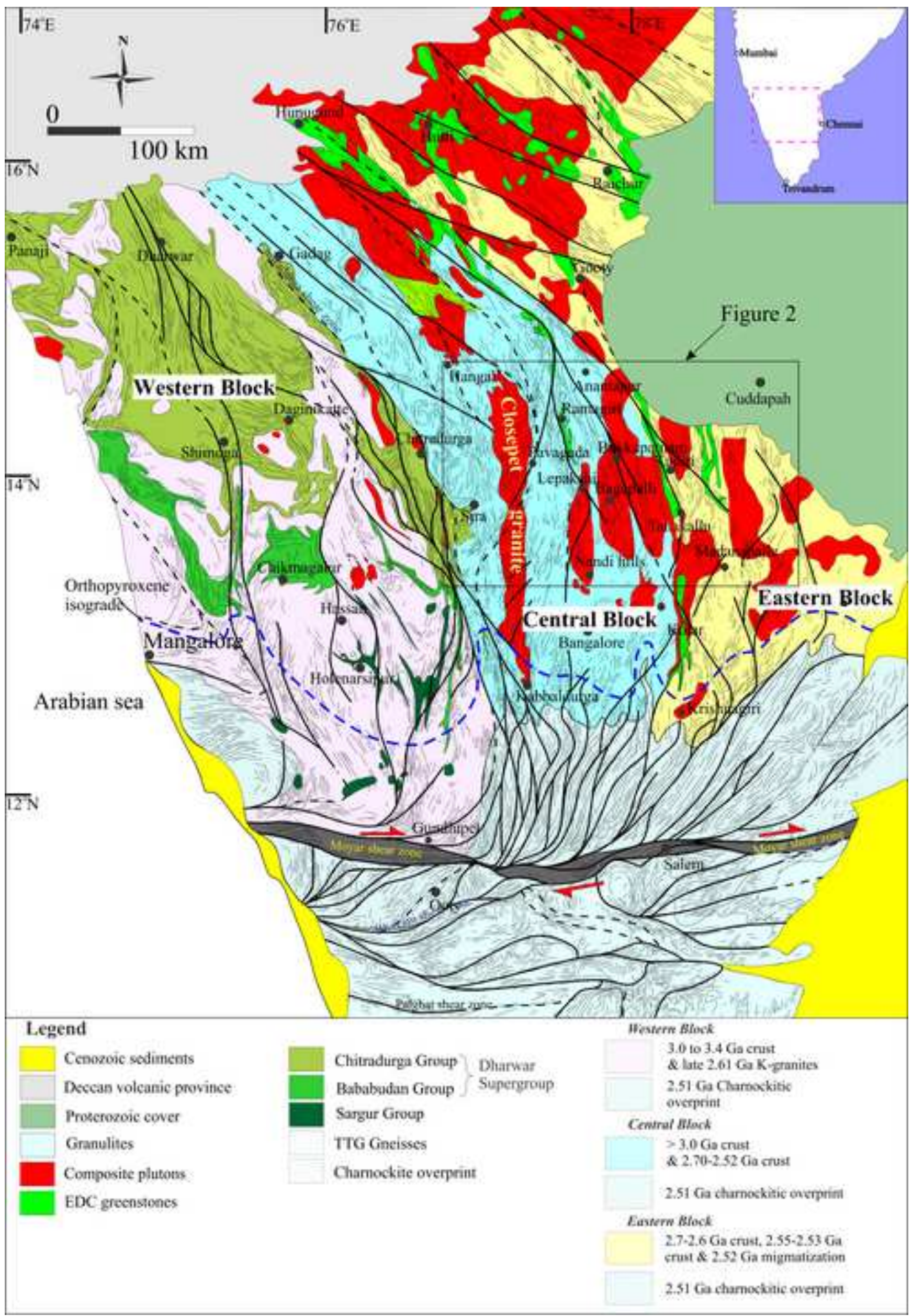




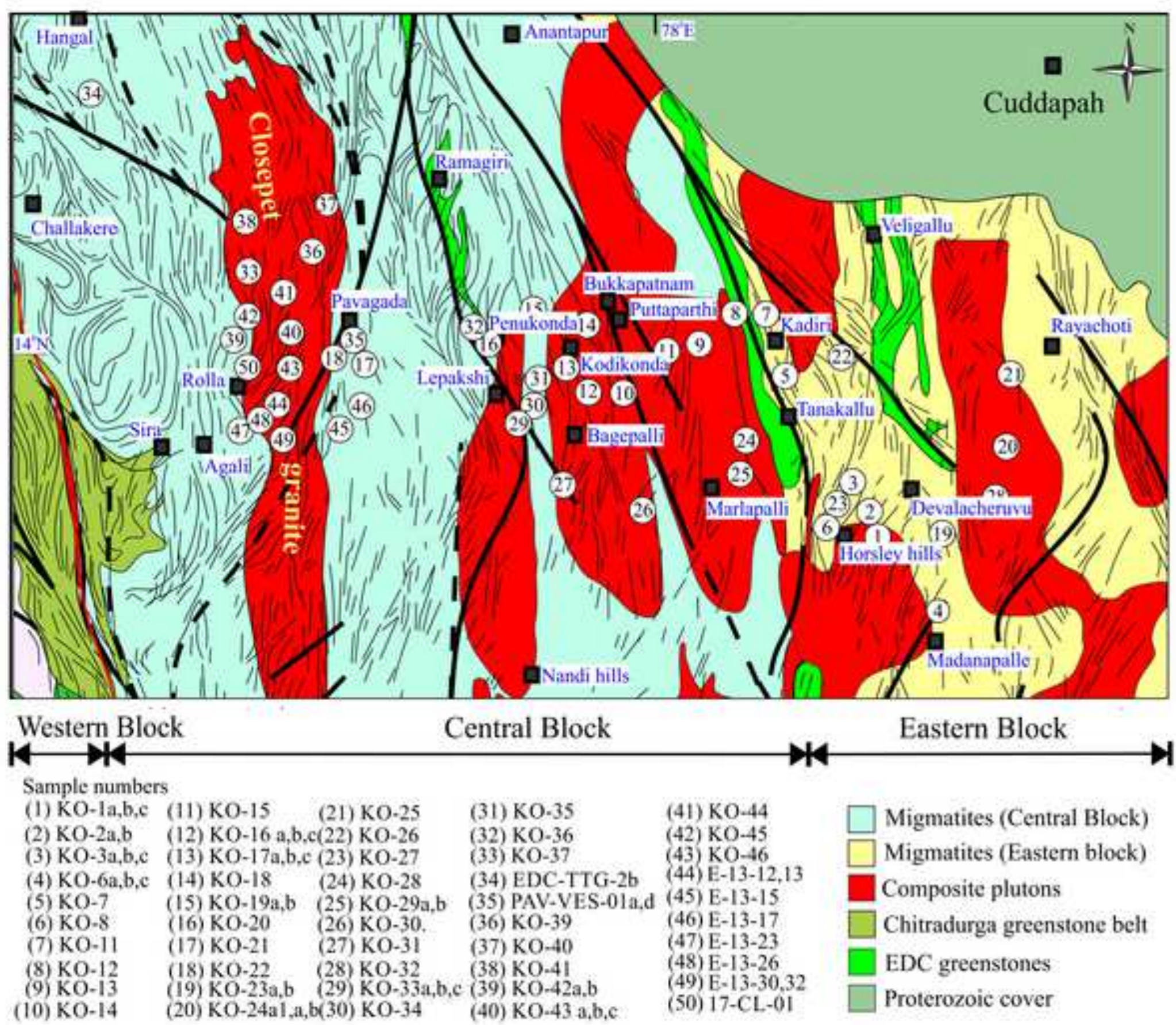

(50) $17-\mathrm{CL}-0 \mathrm{I}$

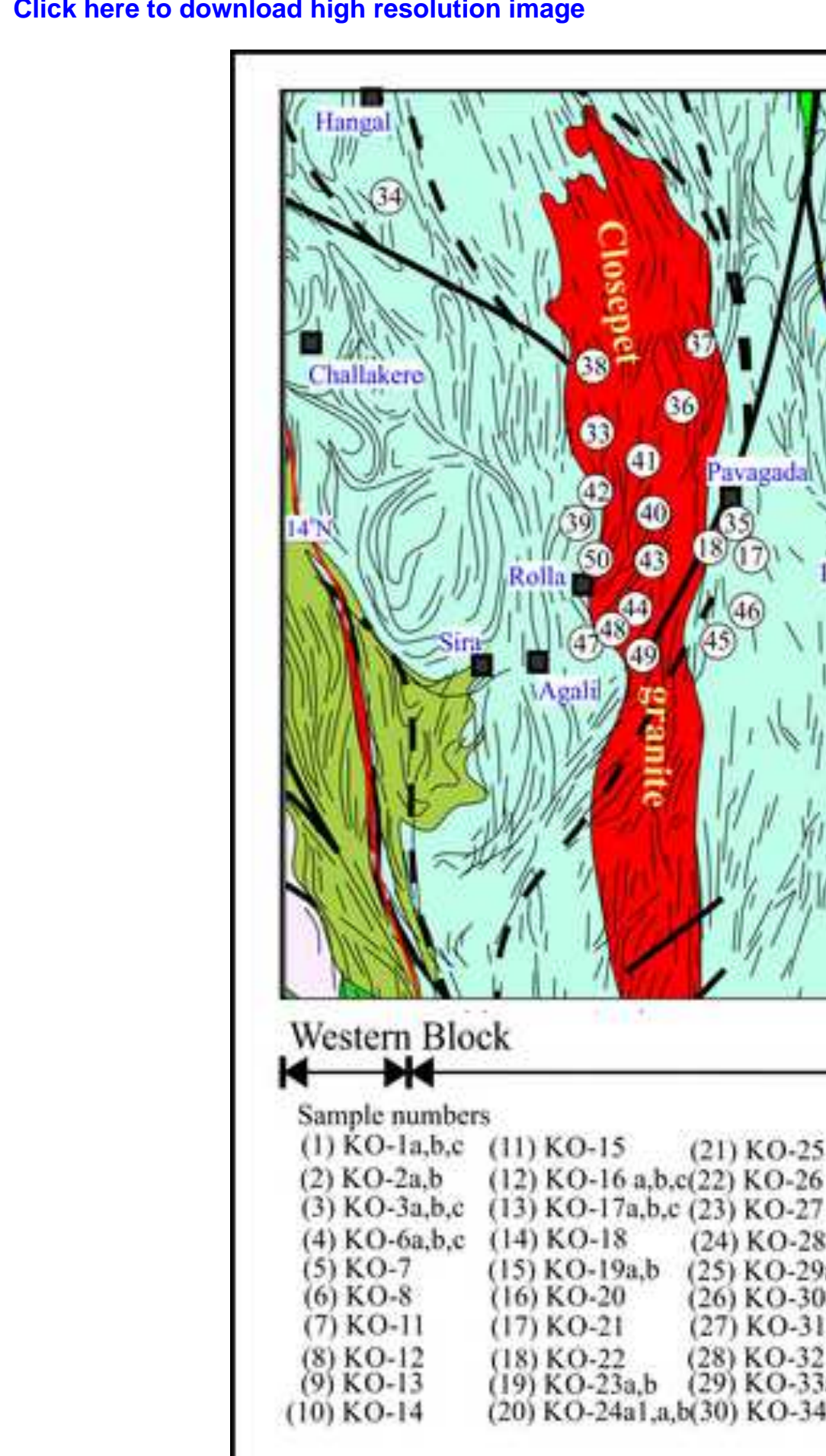

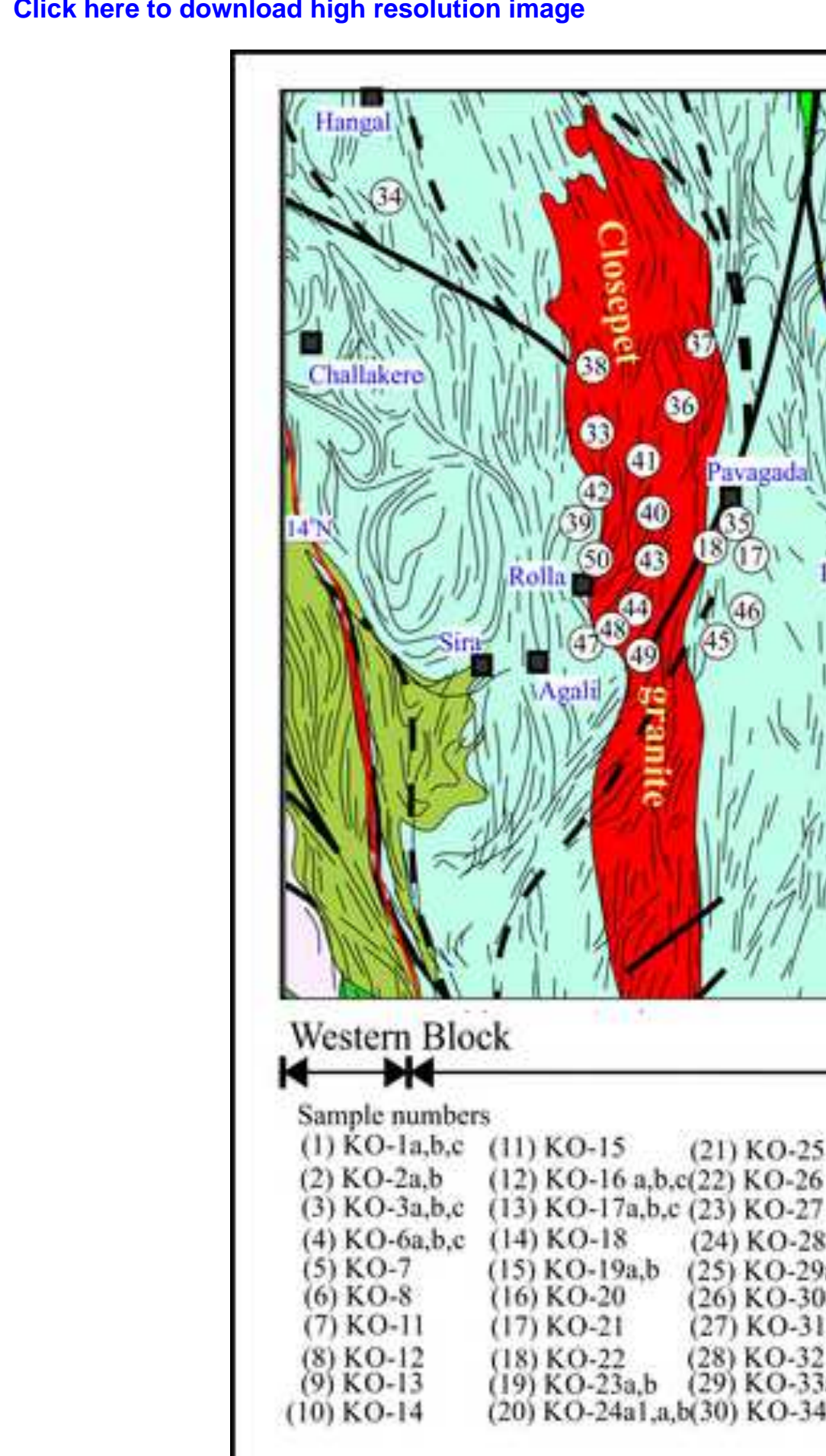

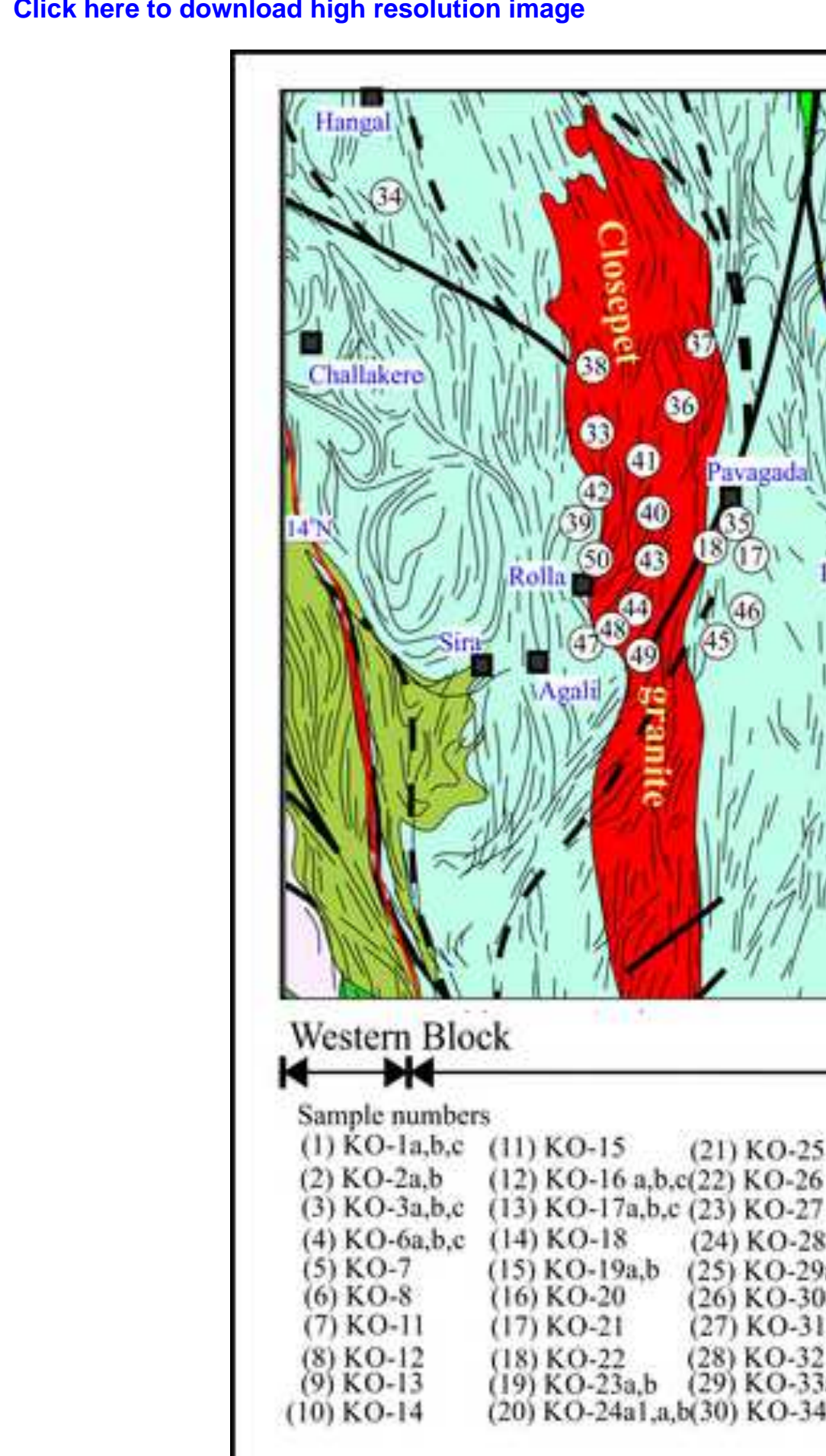

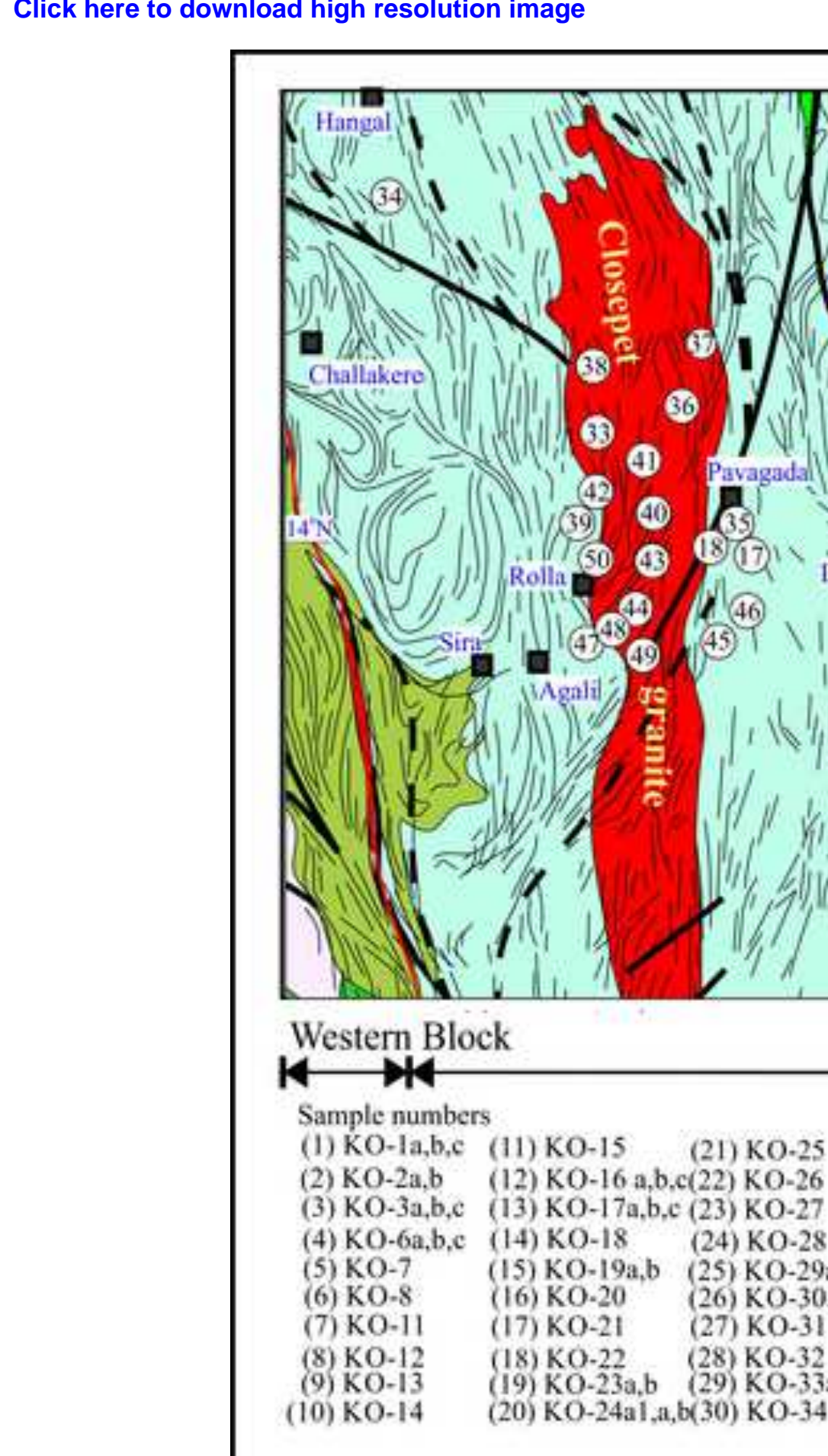

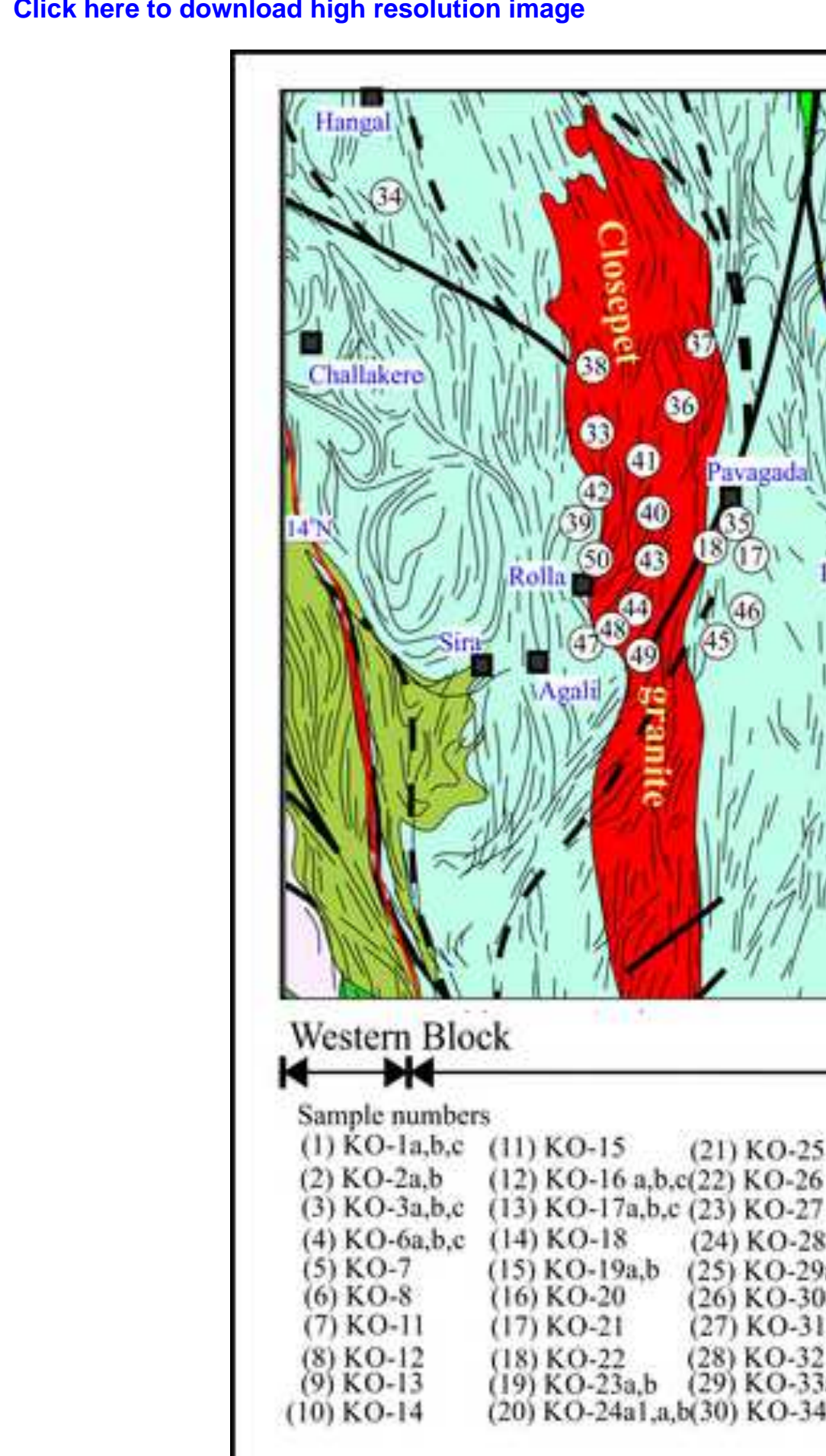

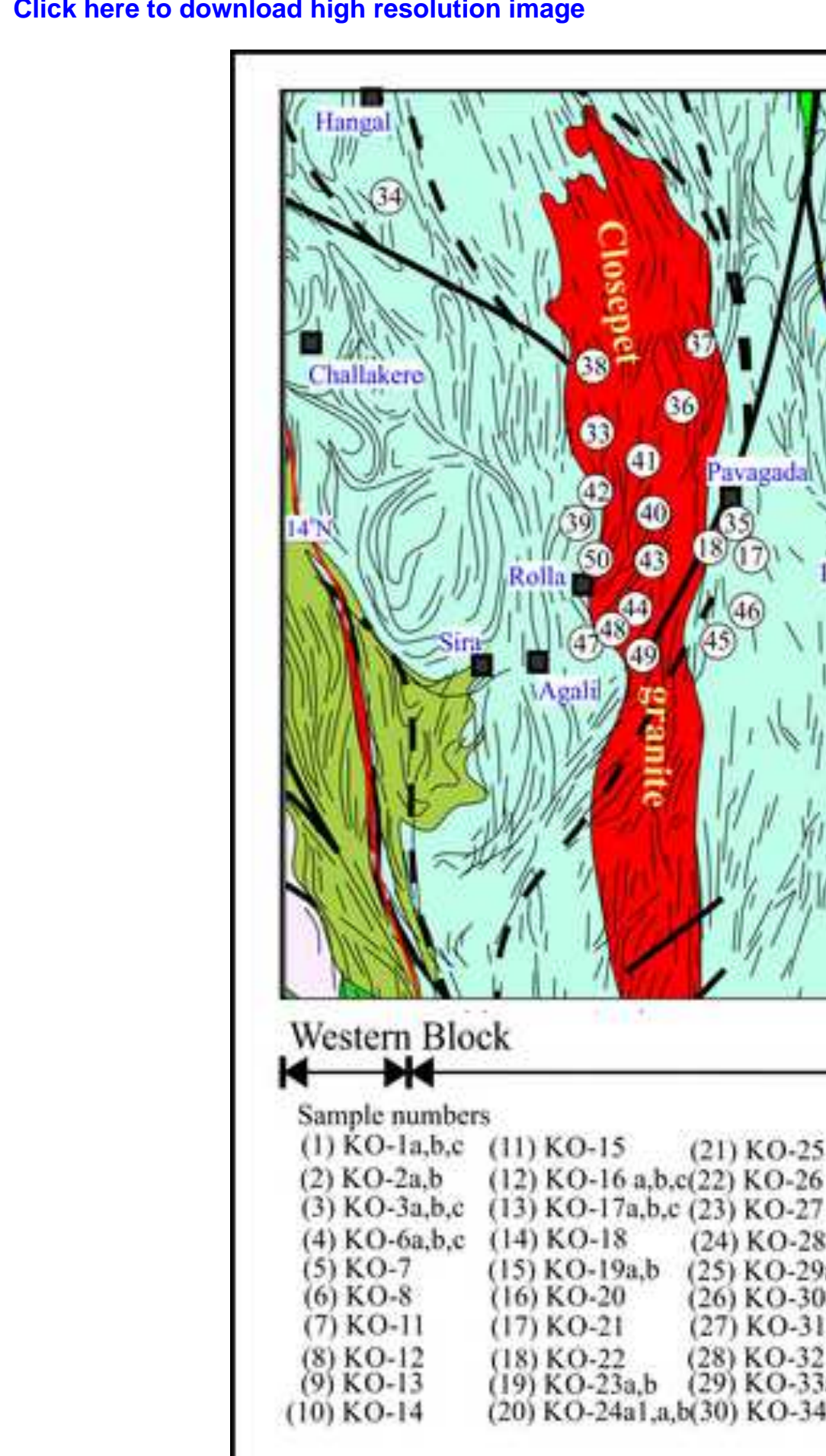

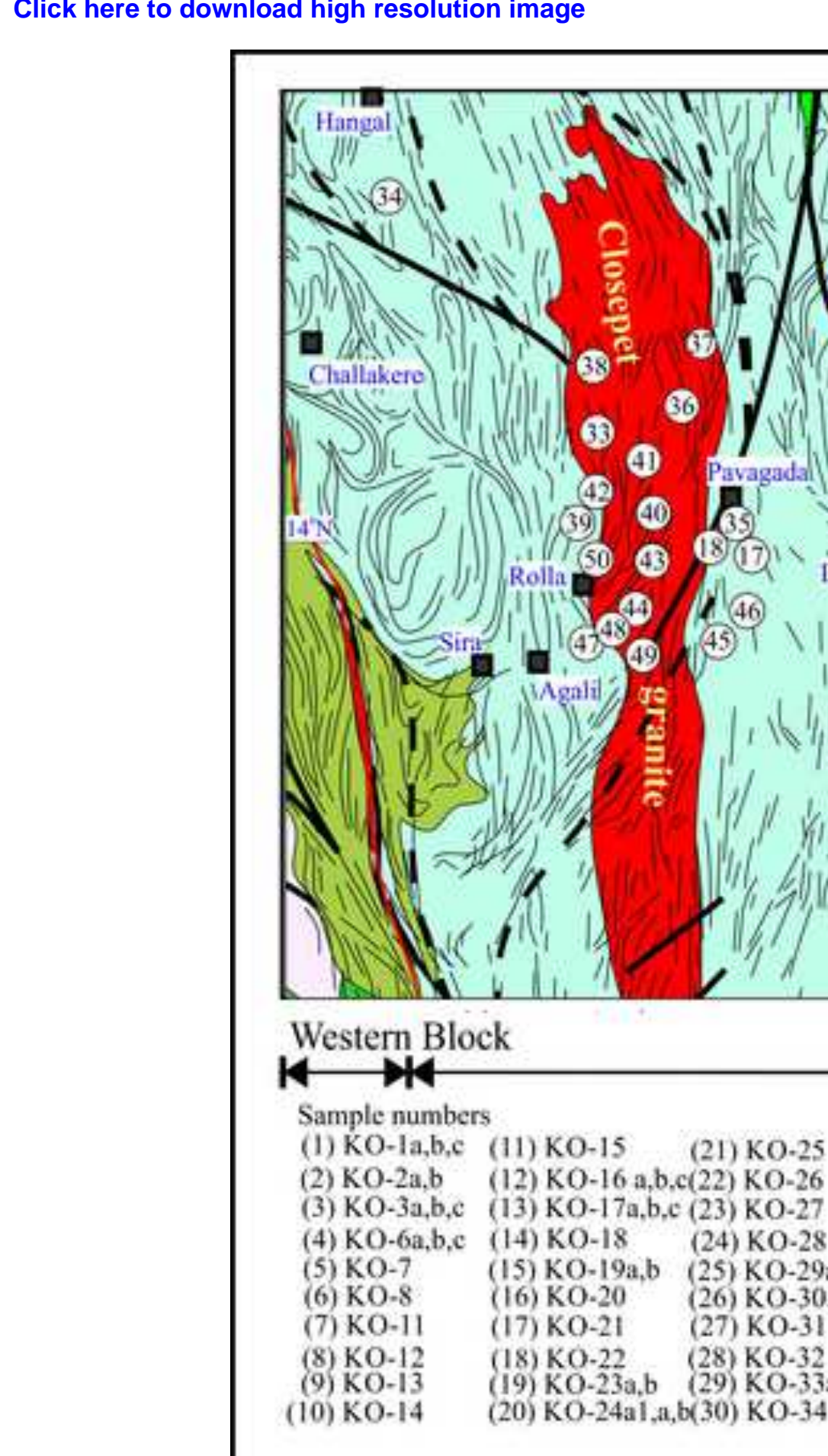

(40) KO. 43 a,b,c

(41) $\mathrm{KO}-44$
(42) $\mathrm{KO}-45$

$43) \mathrm{KO}_{4} 46$

(35) PAV VES-0IAd

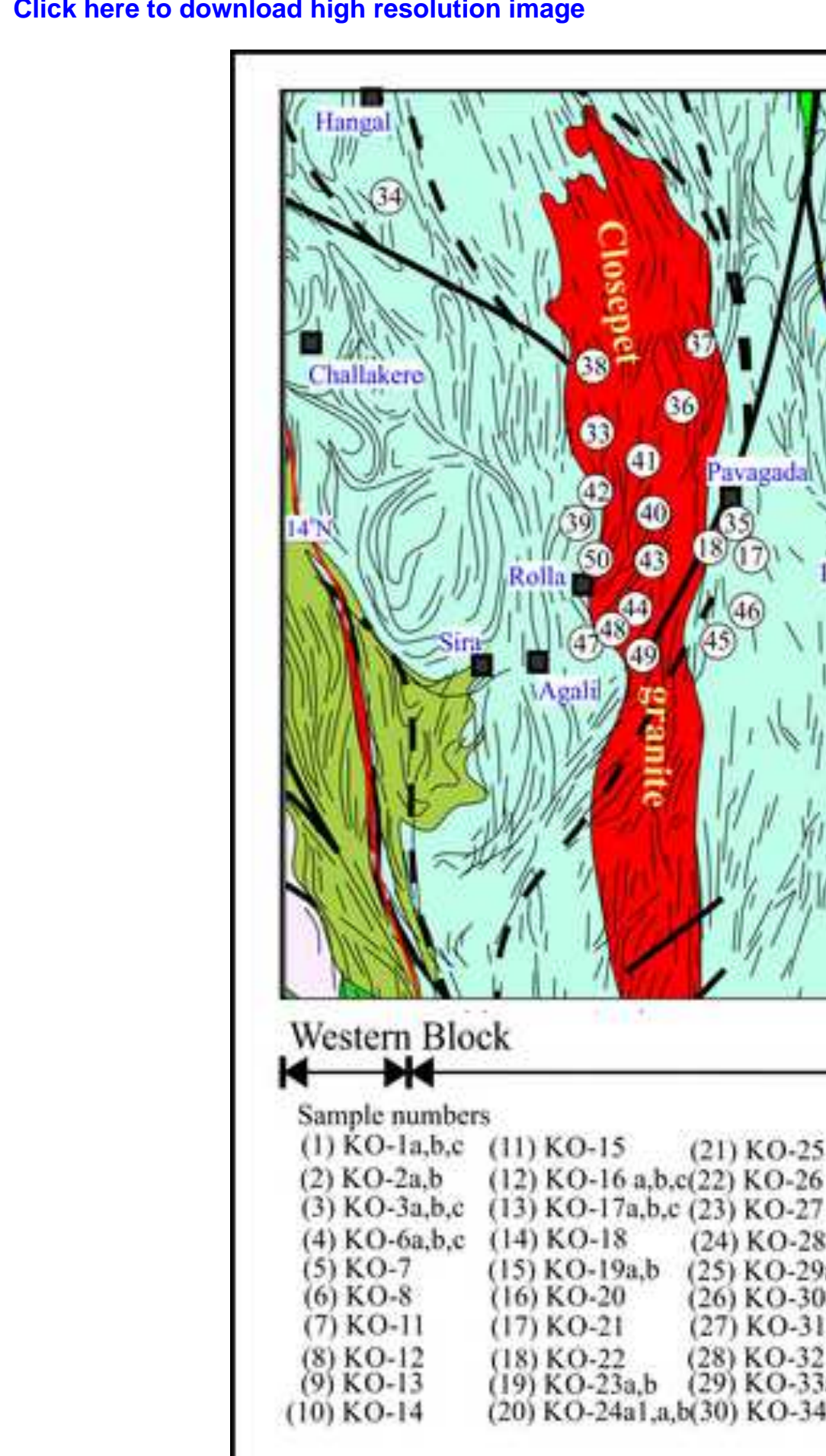

$\square$ Migmatites (Central Block) Migmatites (Eastern block) Composite plutons

Chitradurga greenstone belt EDC greenstones Proterozoic cover 


\section{Figure}

Click here to download high resolution image
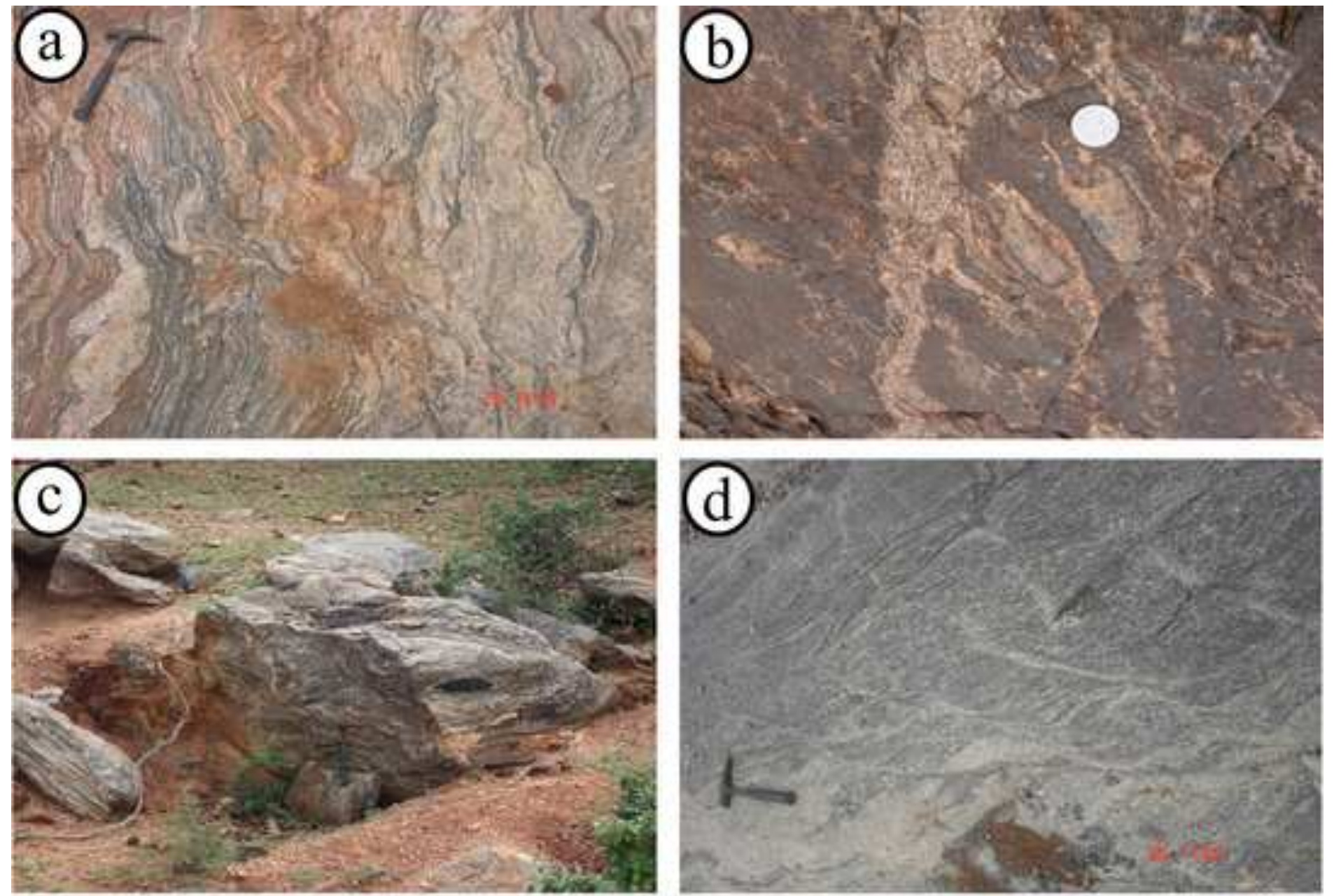

\section{(C)}

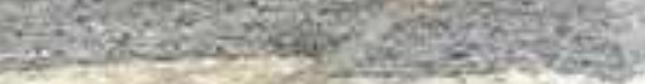

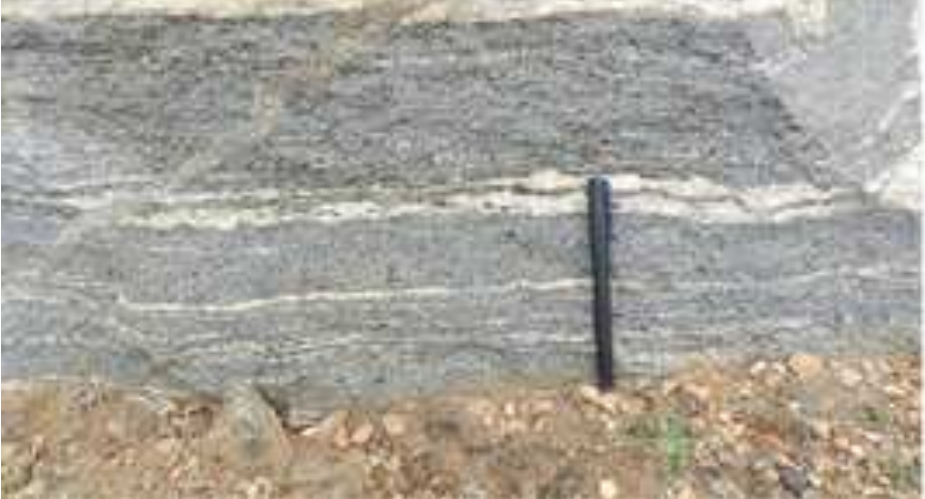

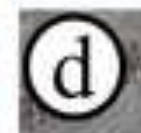

(d)
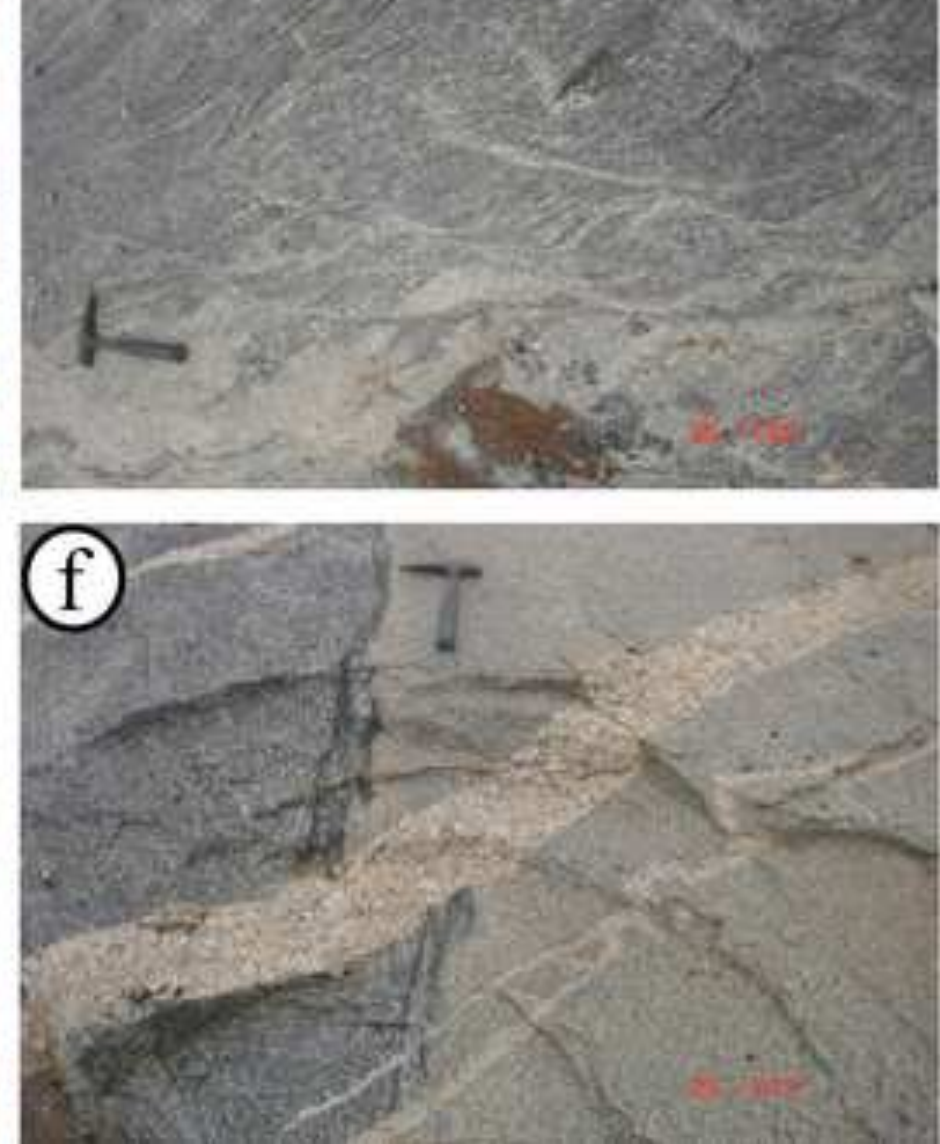

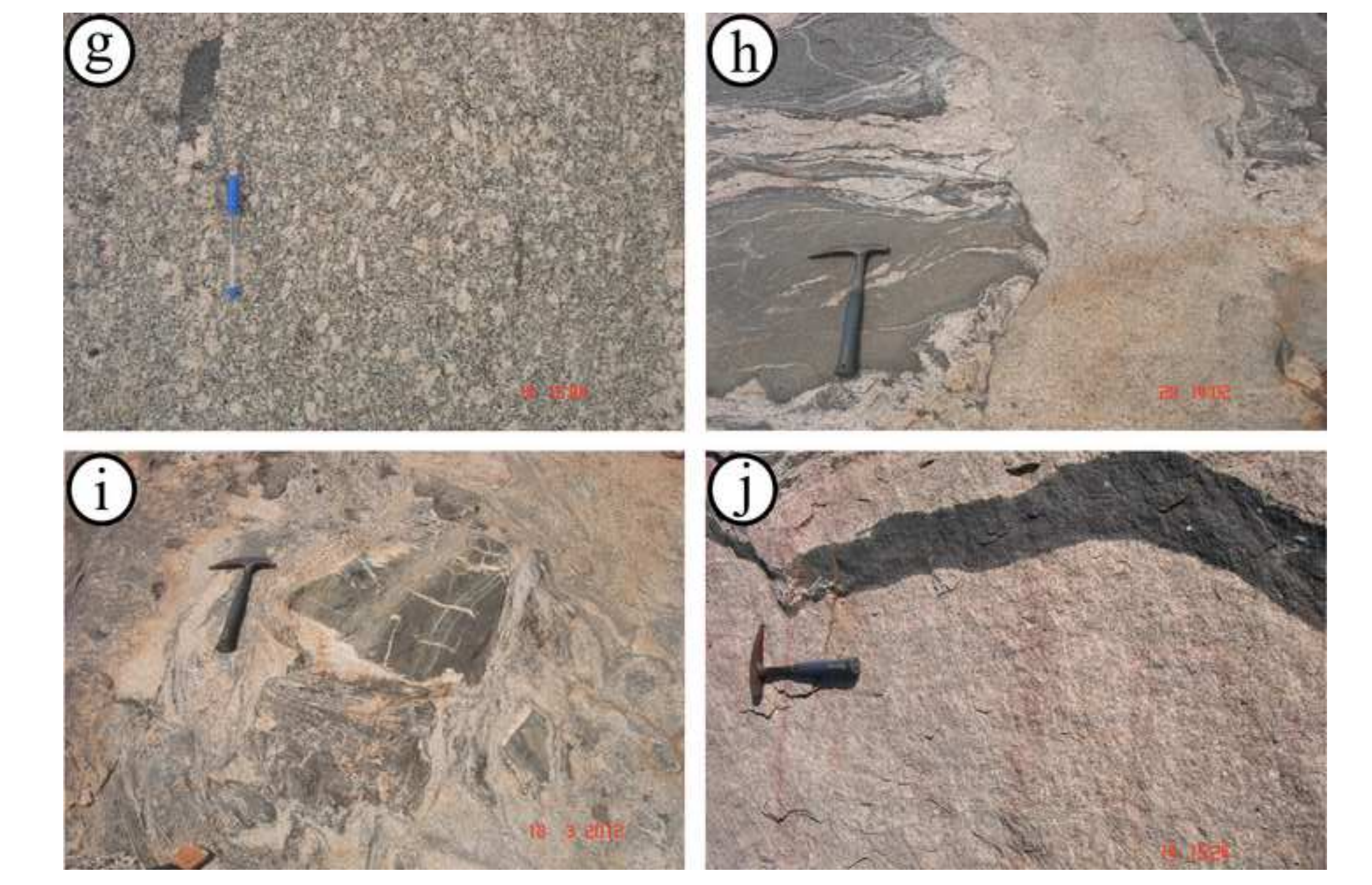

ro to dowenload high rocolution imaco

click here to download high resolution image 
Click here to download high resolution image
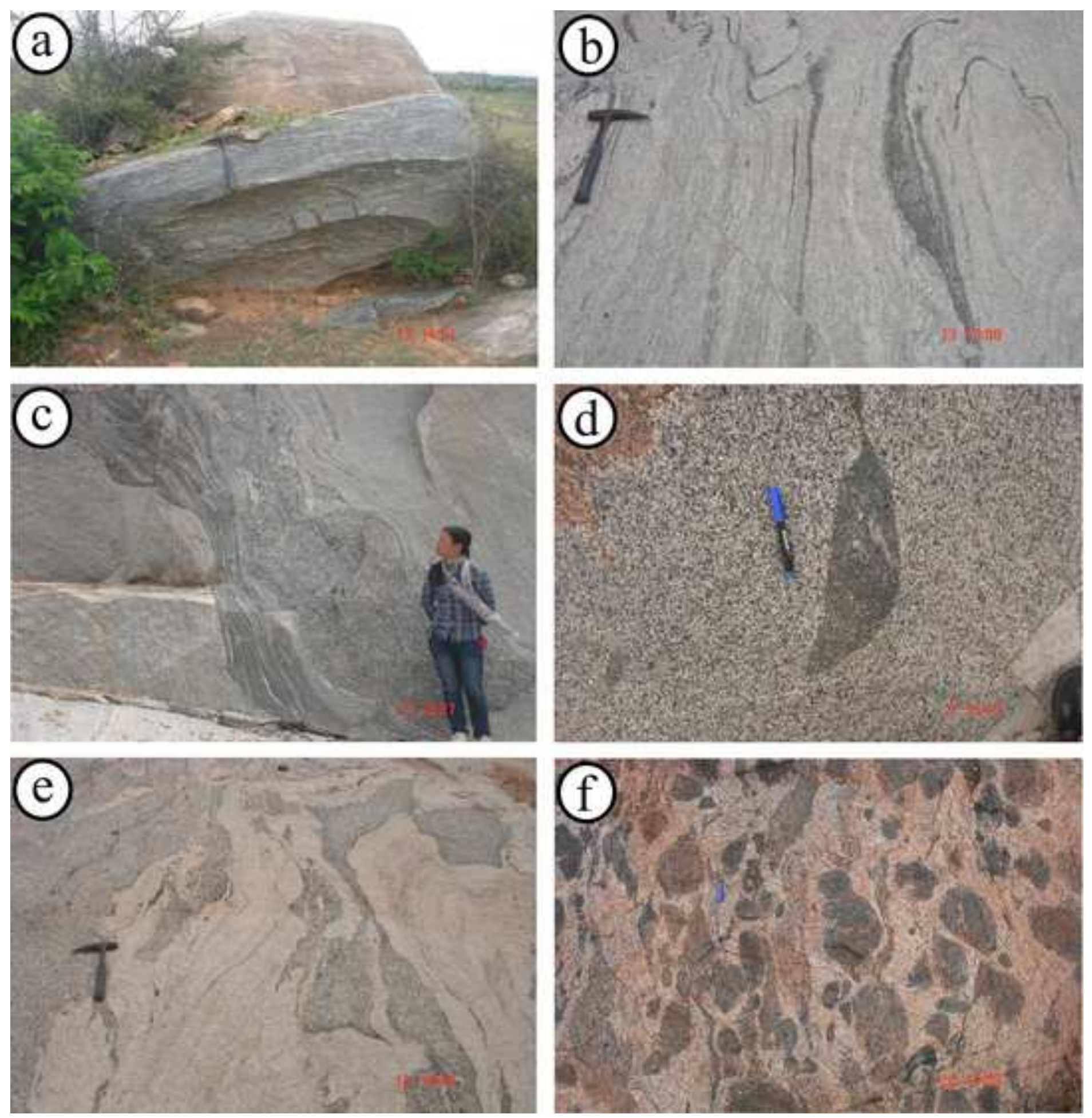

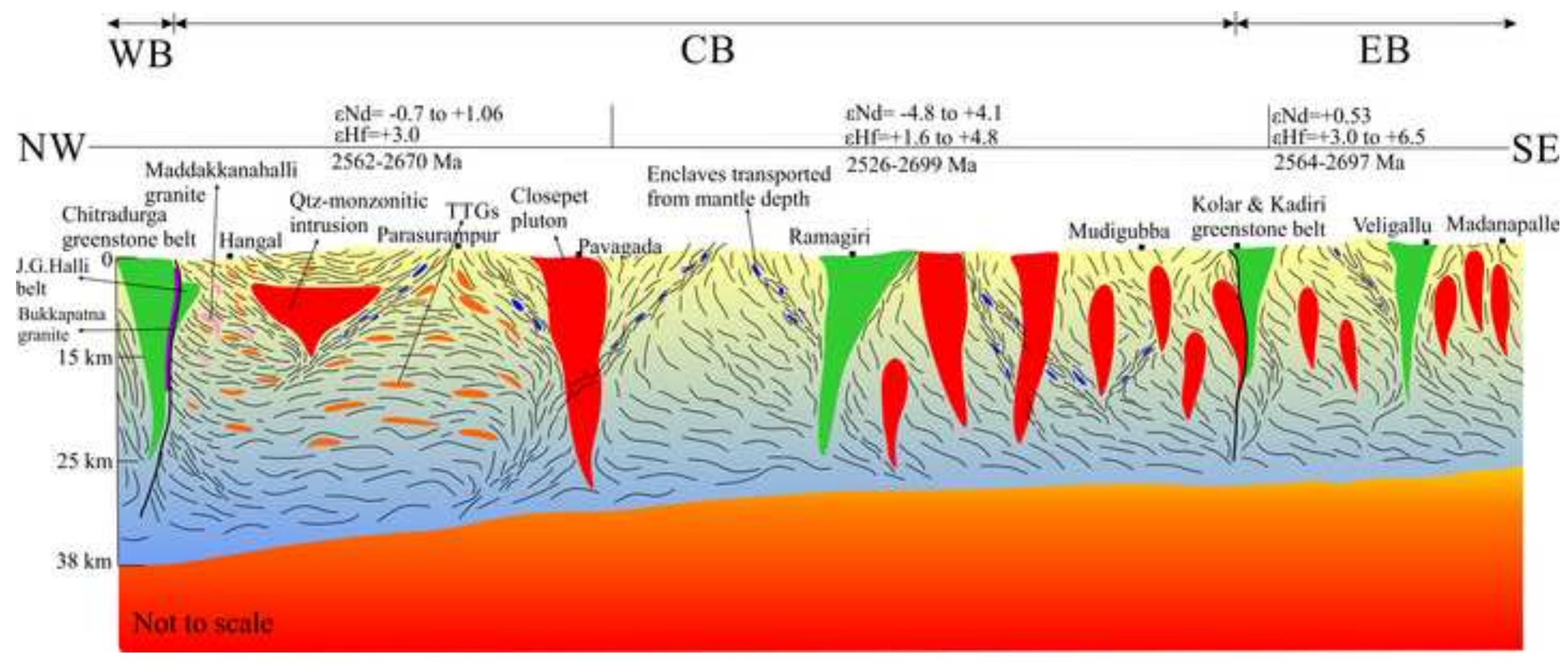
Click here to download high resolution image
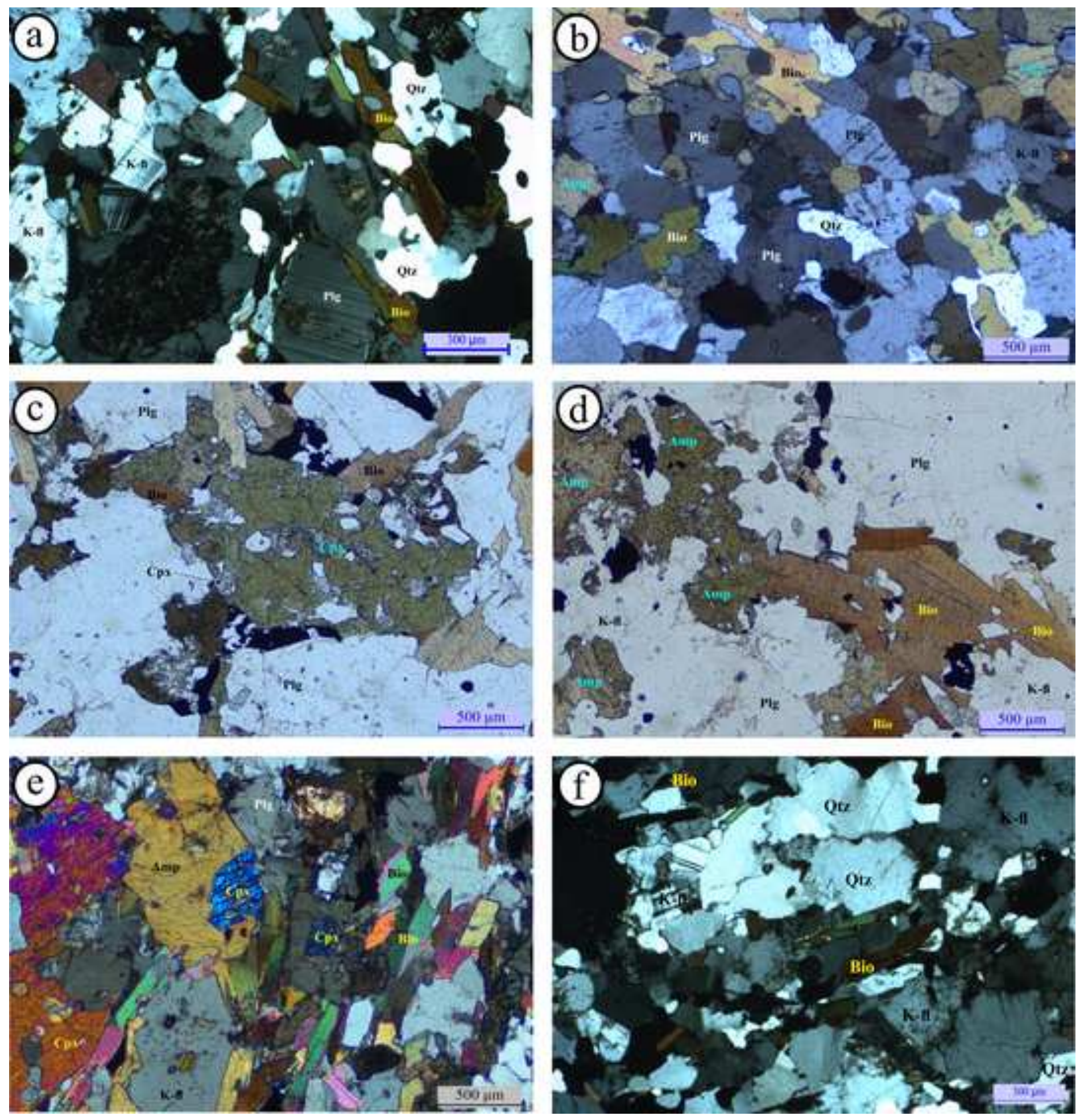
Click here to download high resolution image
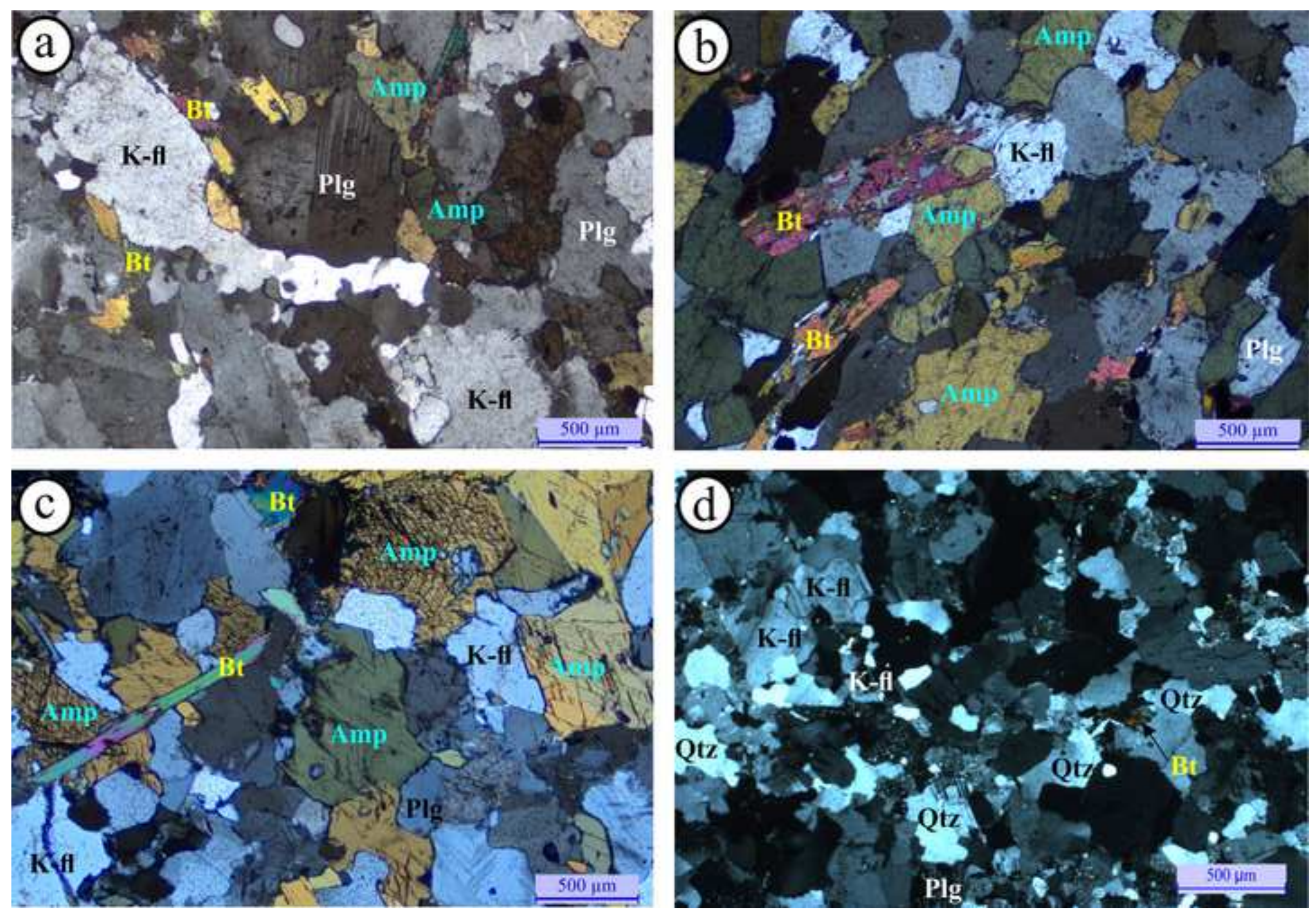

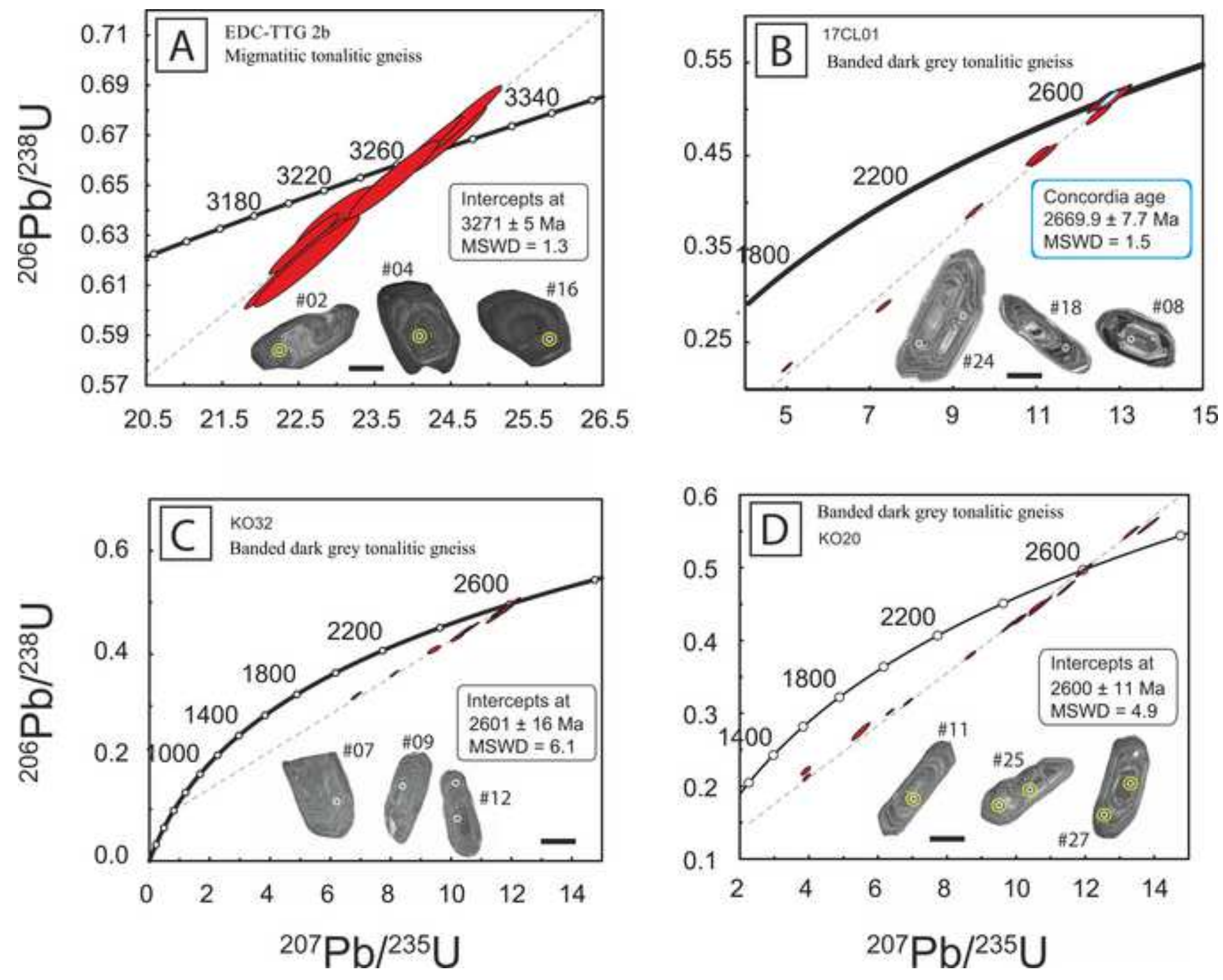

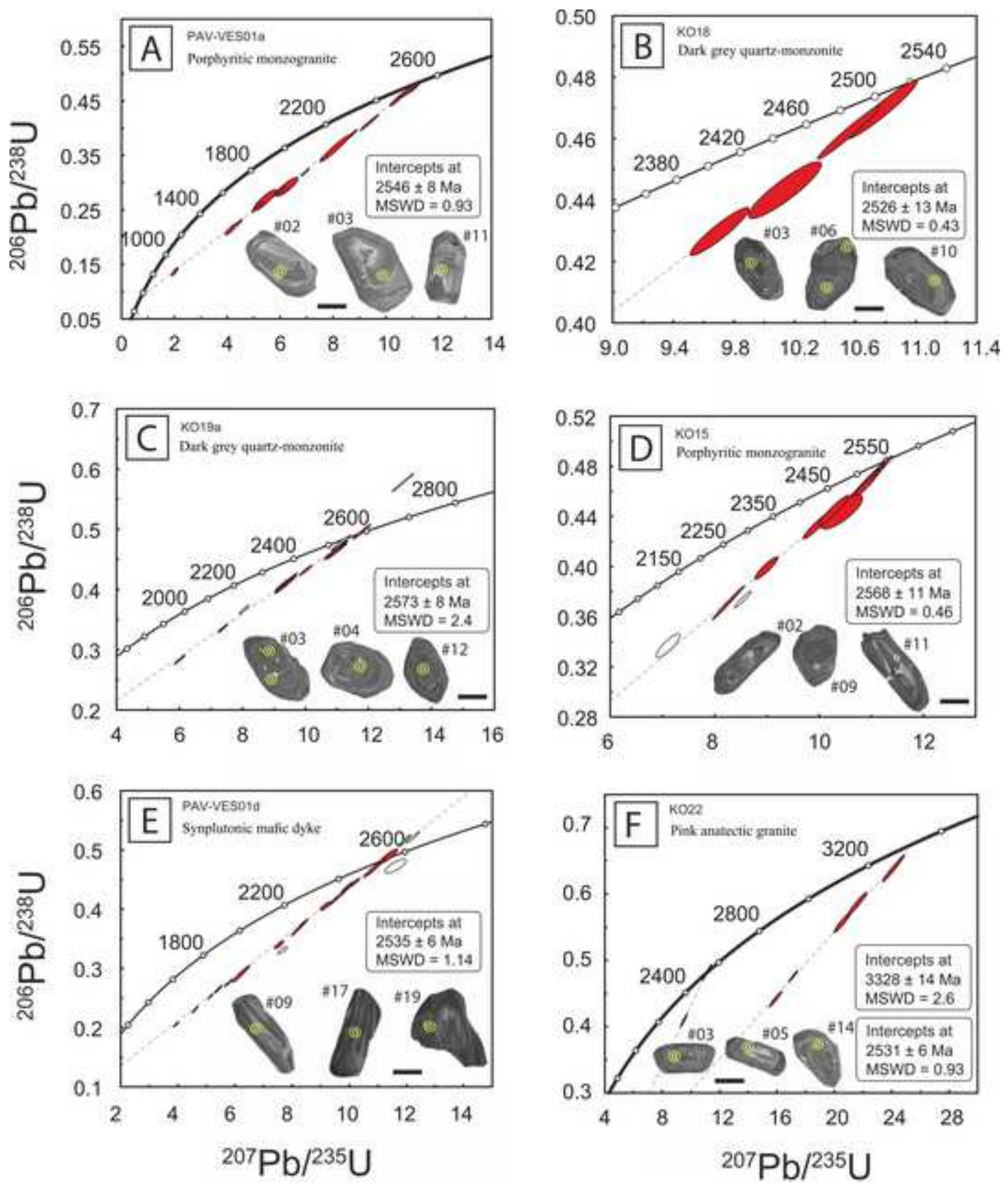

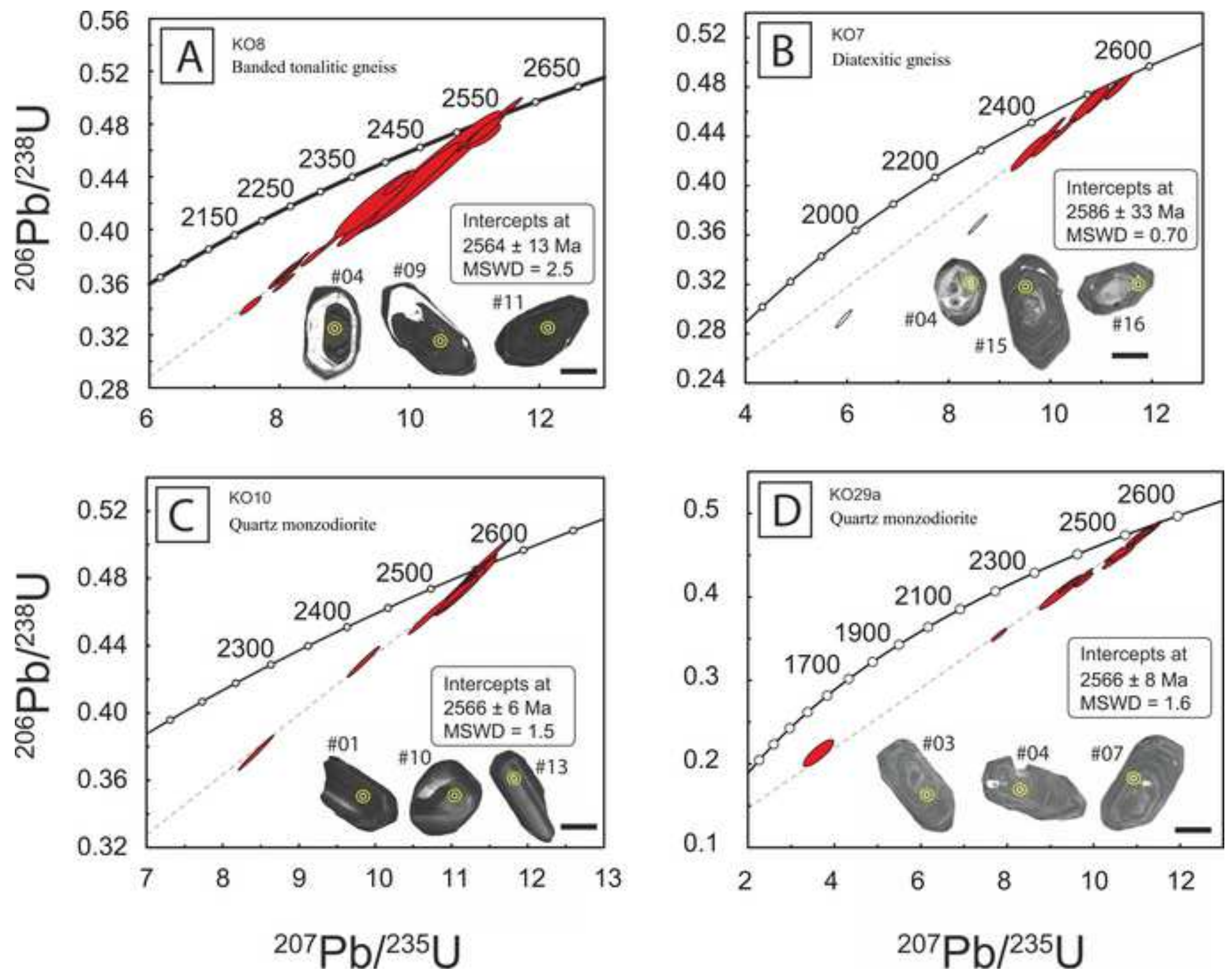


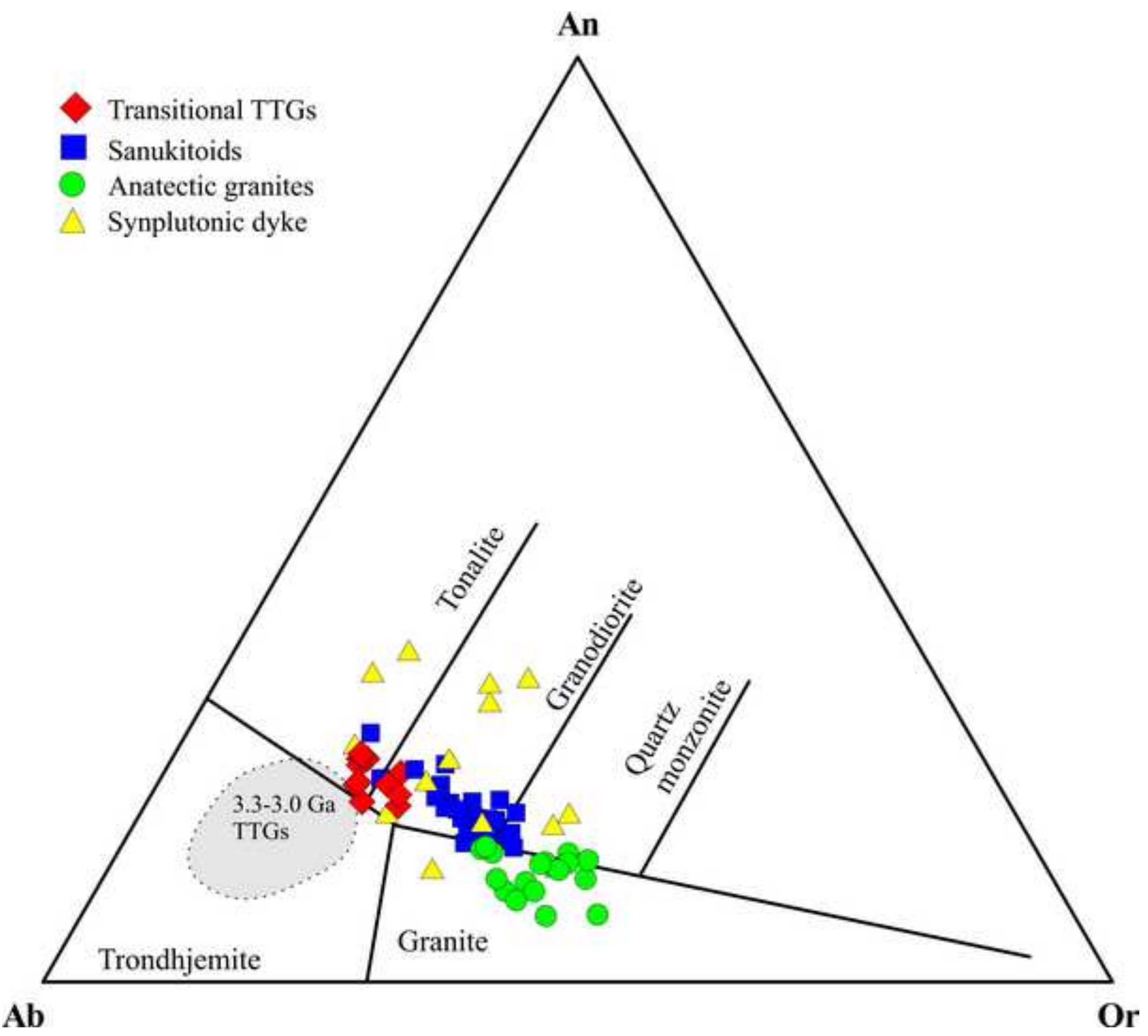




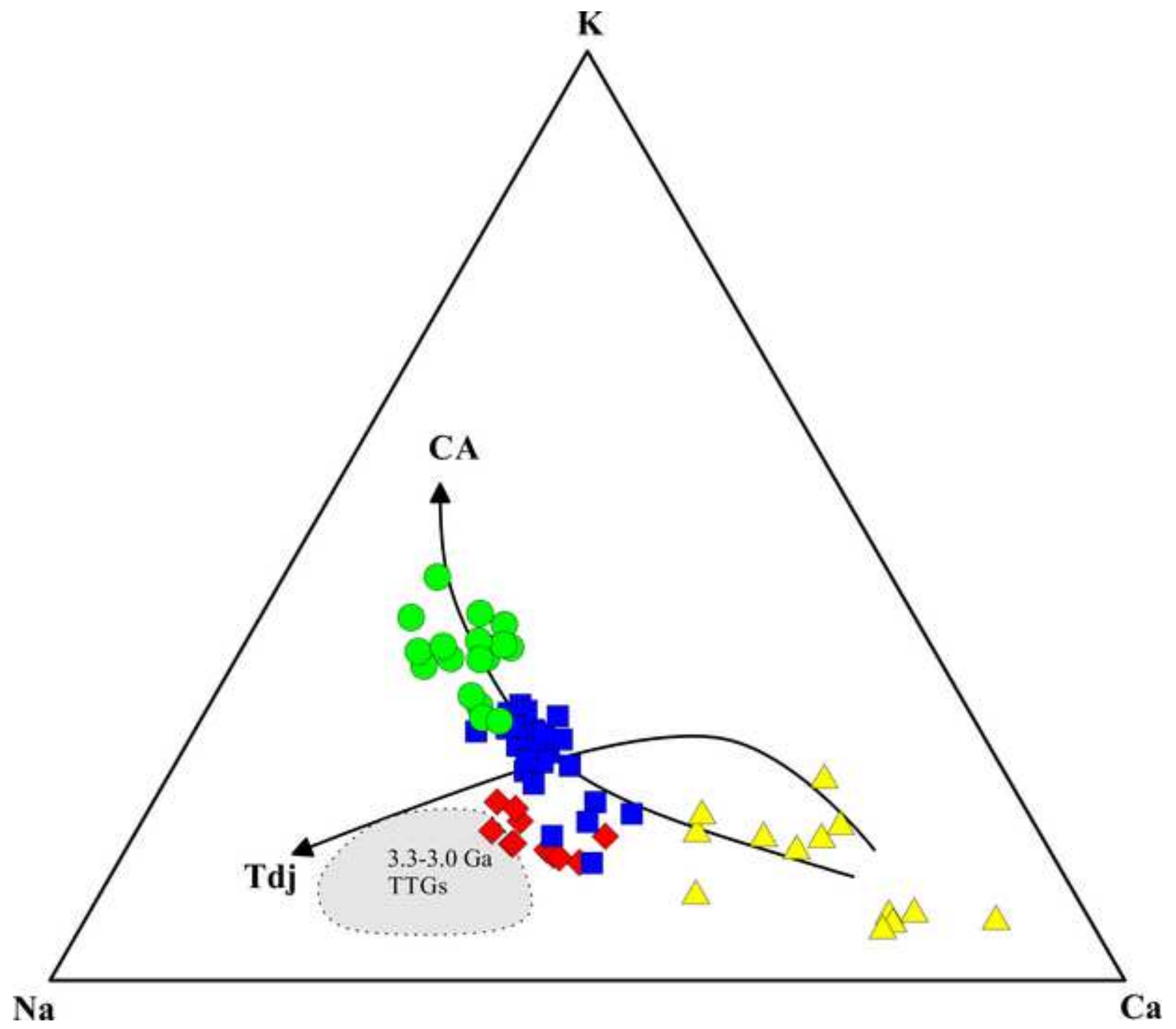


Click here to download high resolution image

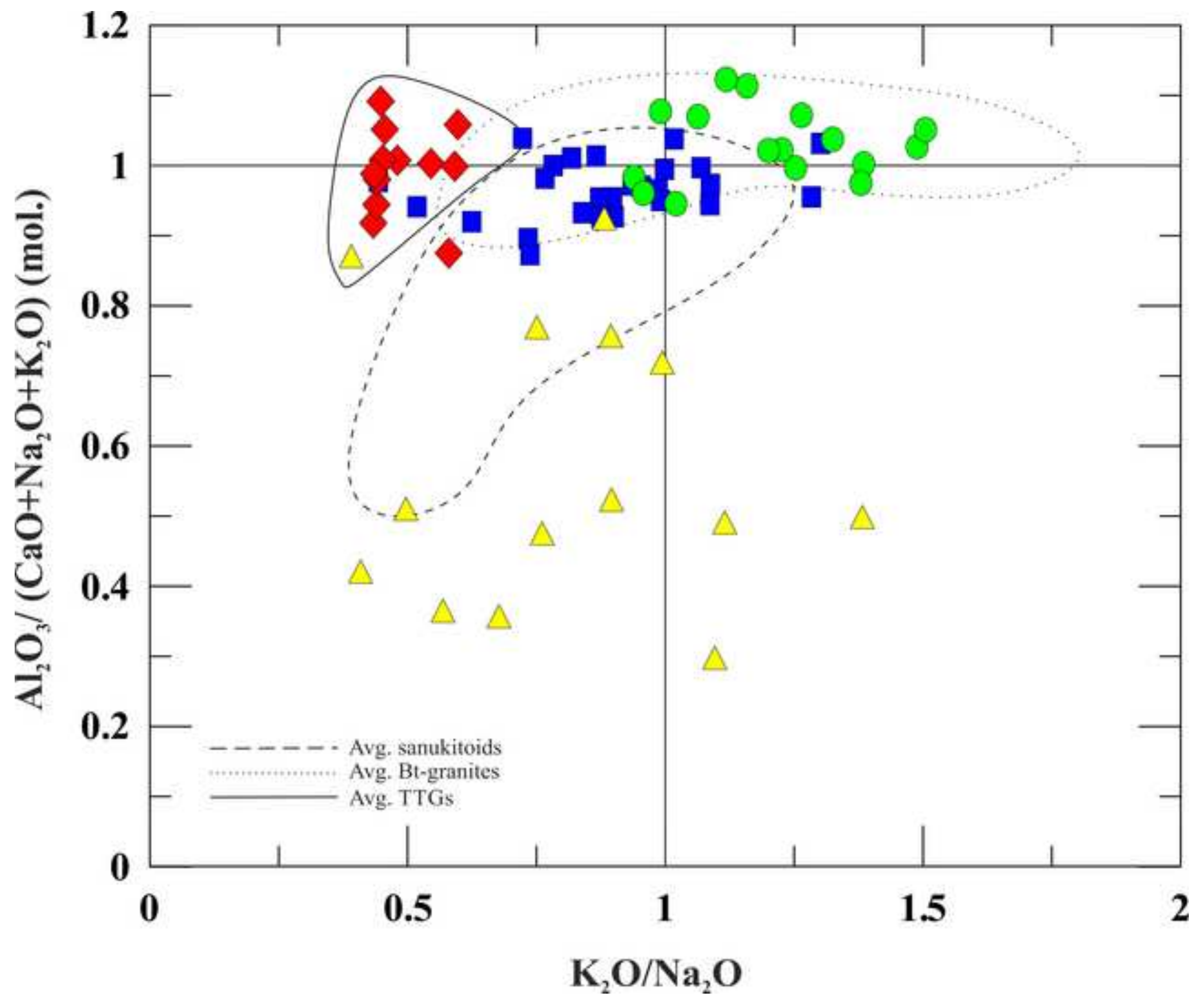




\section{Figure}

Click here to download high resolution image

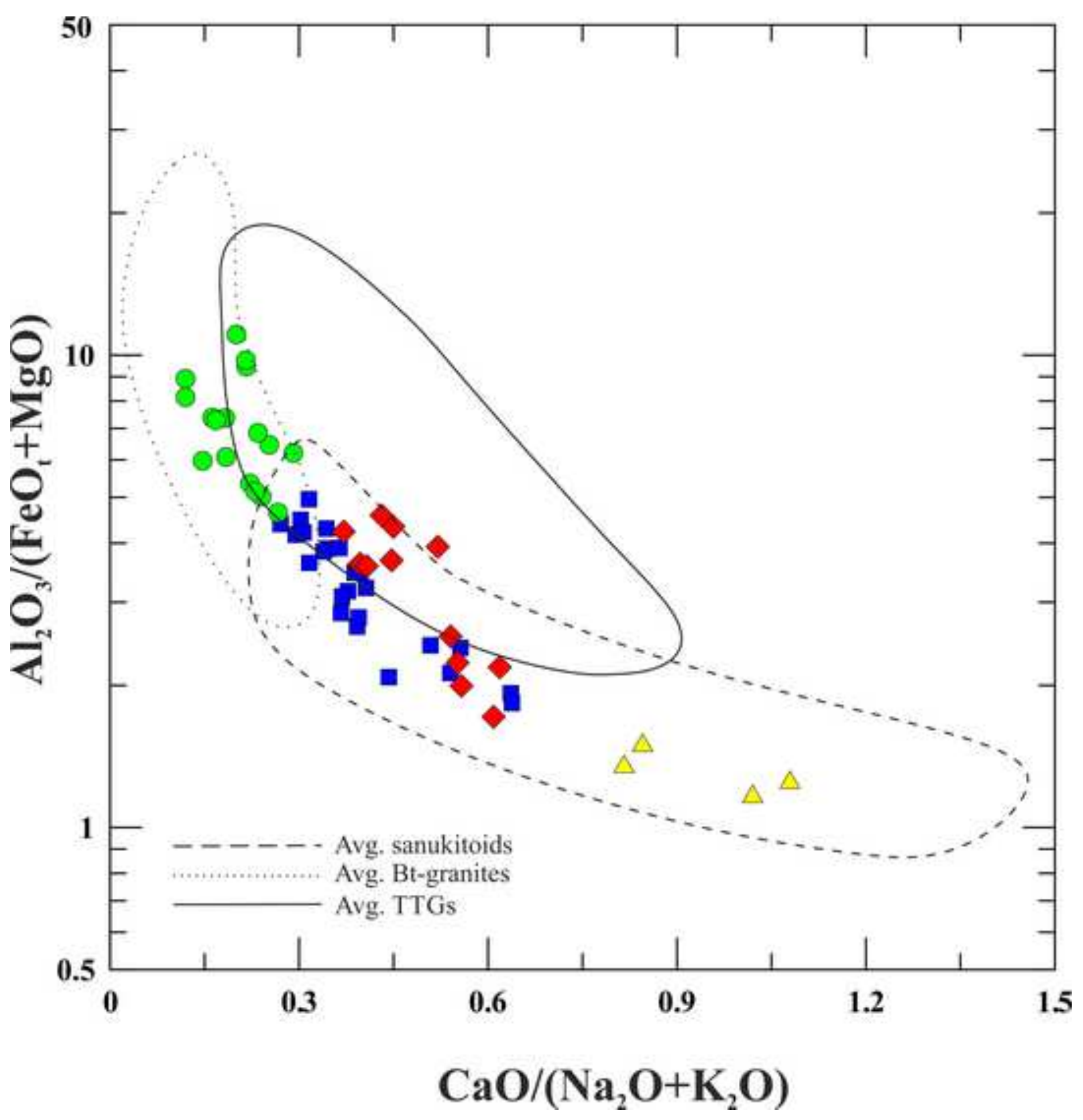


Click here to download high resolution image
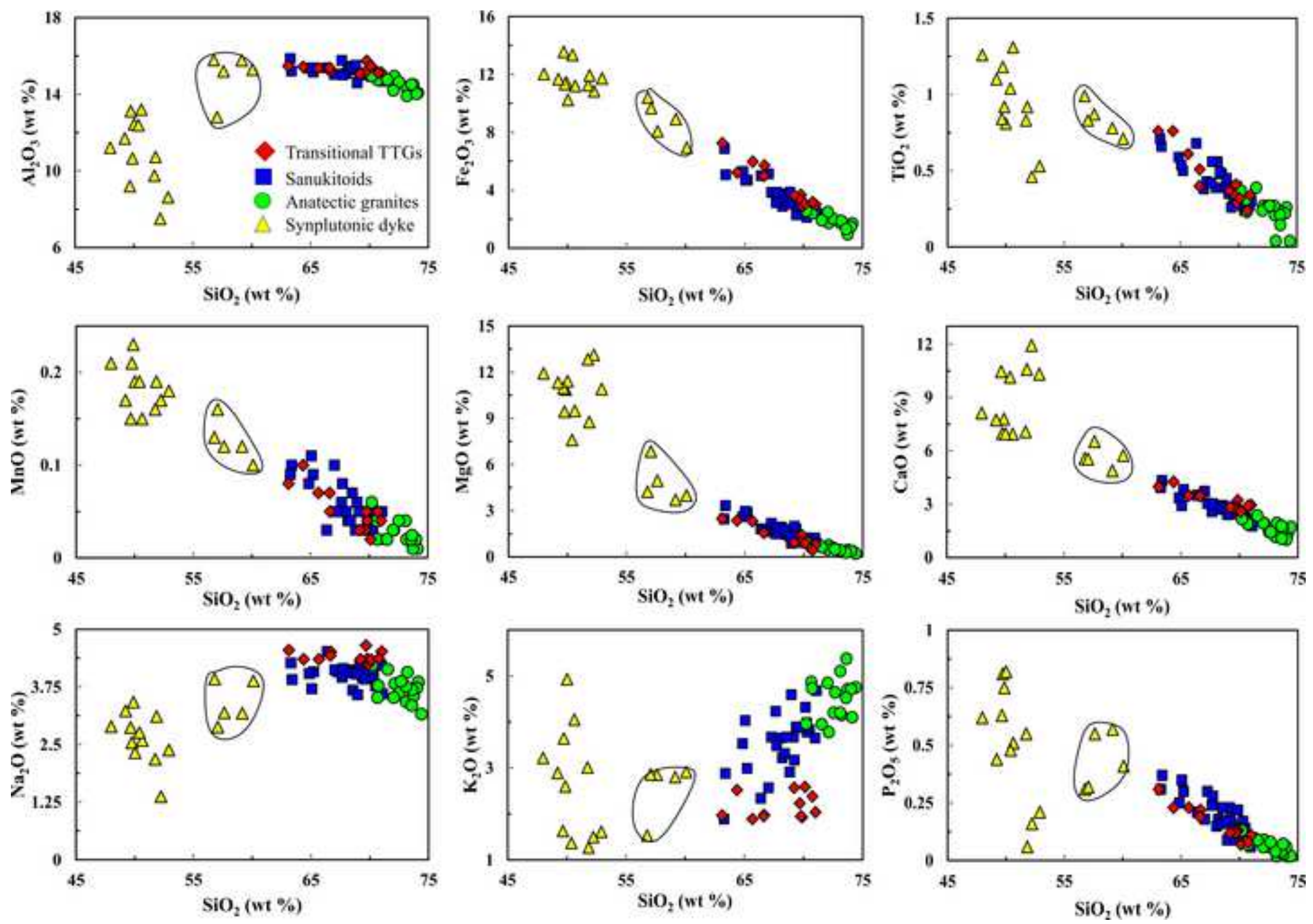

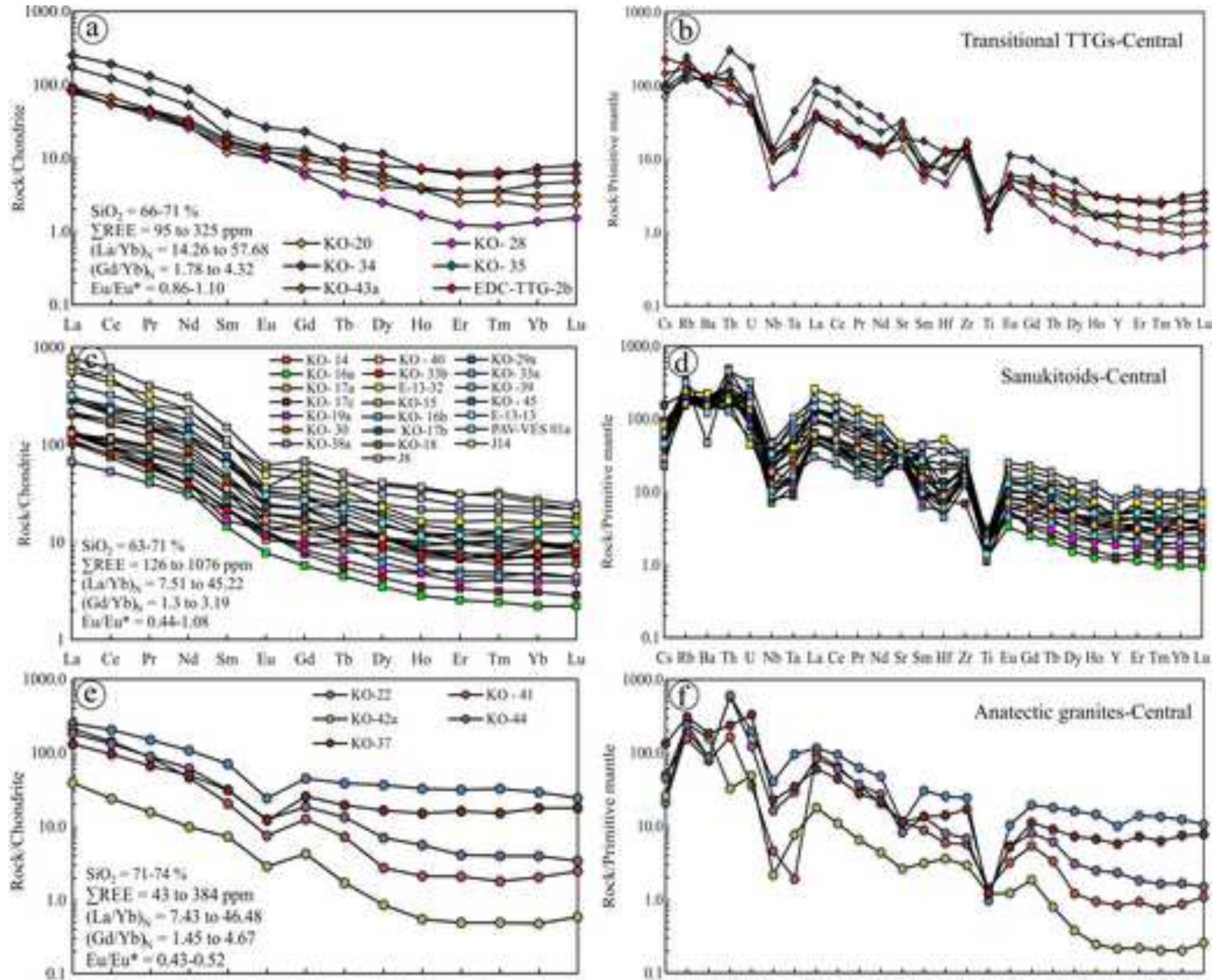

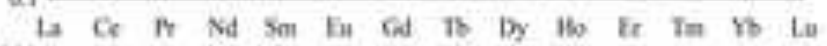
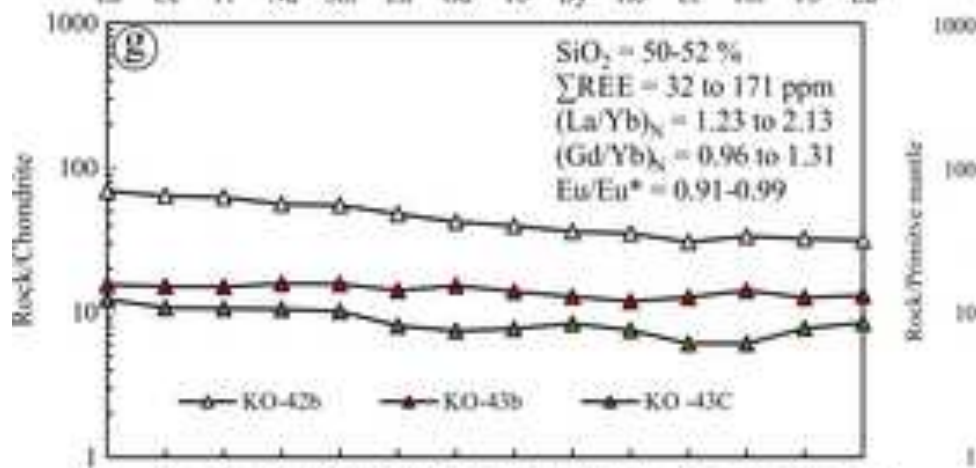

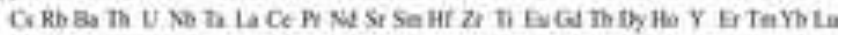
1000

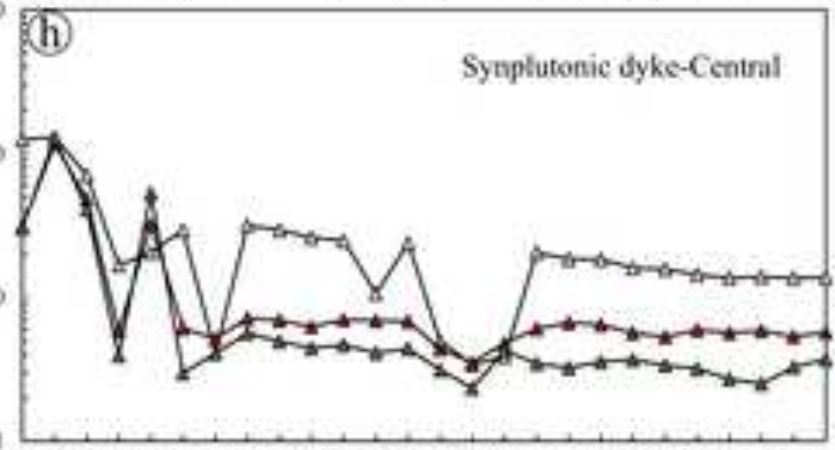

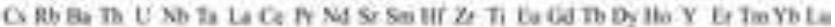
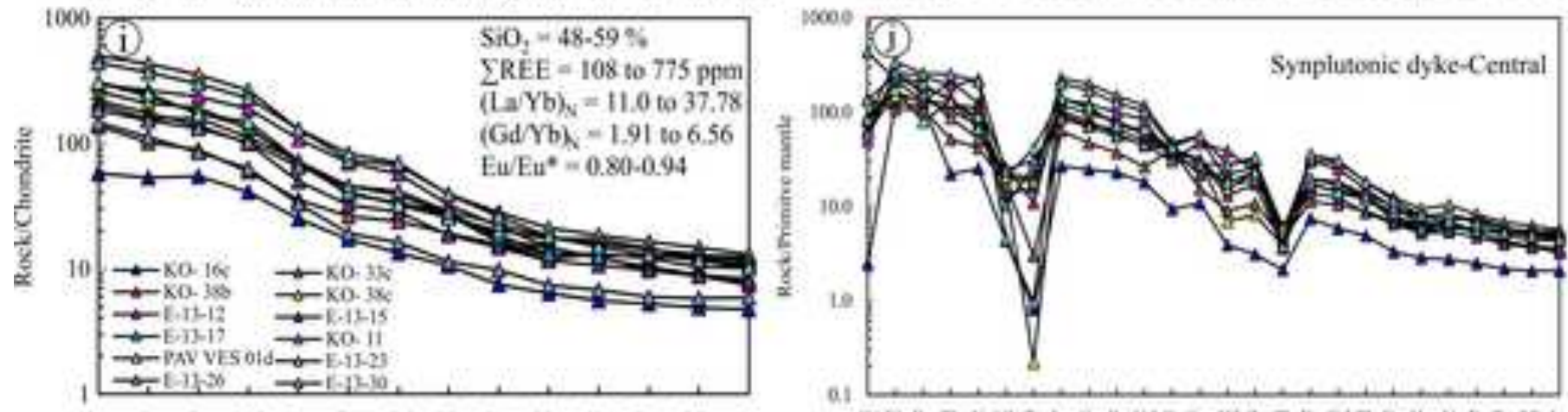

La Ce it Nd Sm Eu Gd To Dy Ho Er Tm Yb Lu

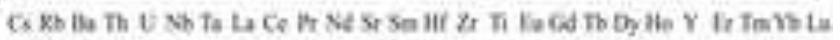



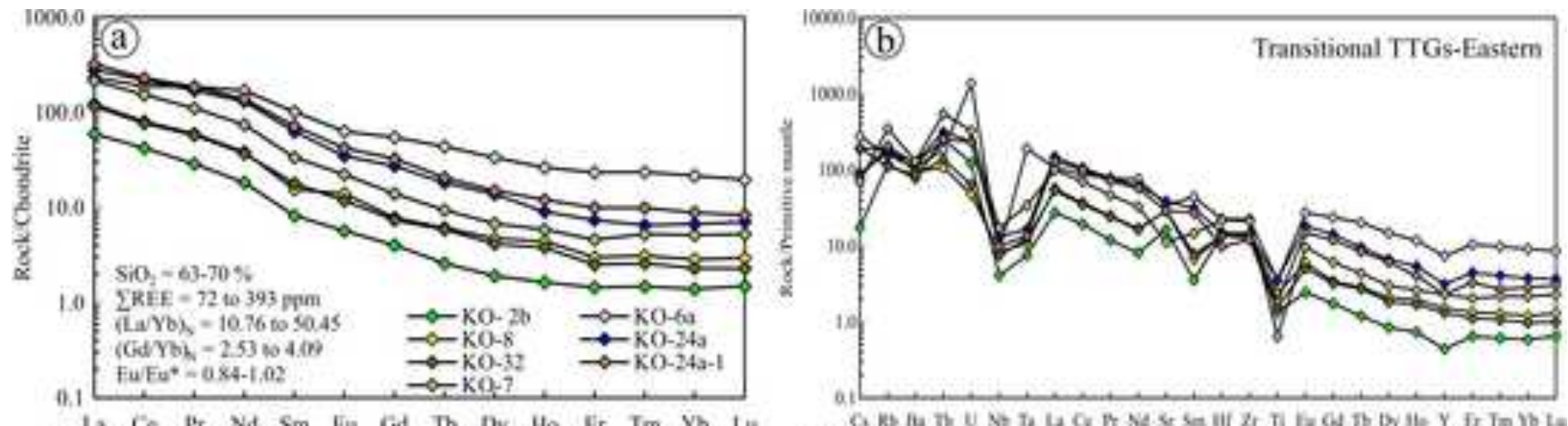

La $\mathrm{Ce}$ Pr Nd Sm Ela Gd Tb Dy Ho Er Tm Yb Le
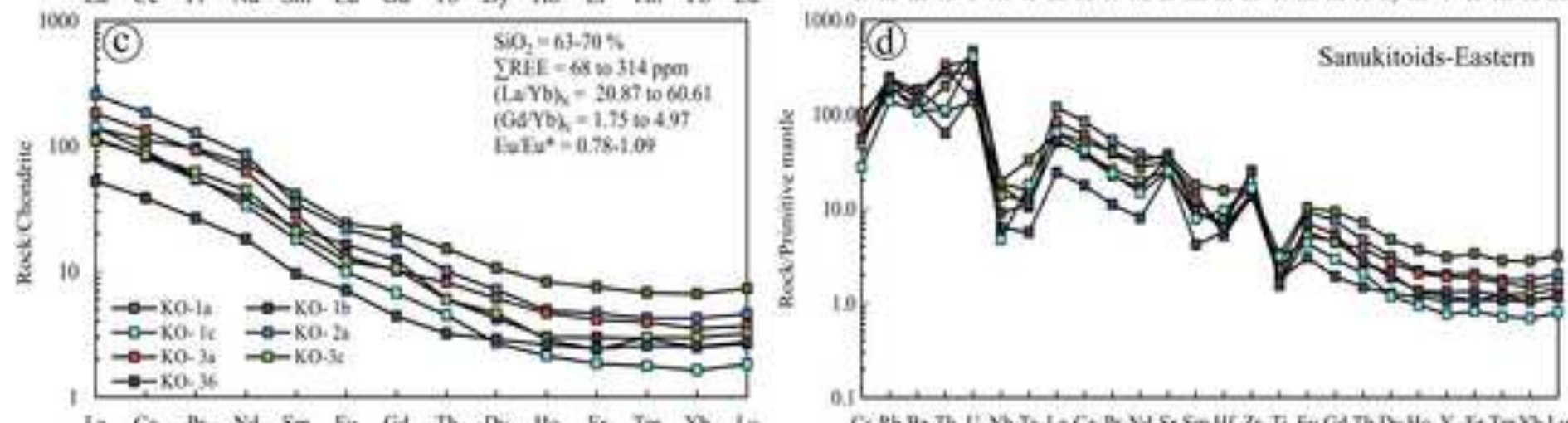

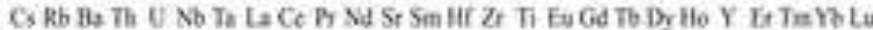
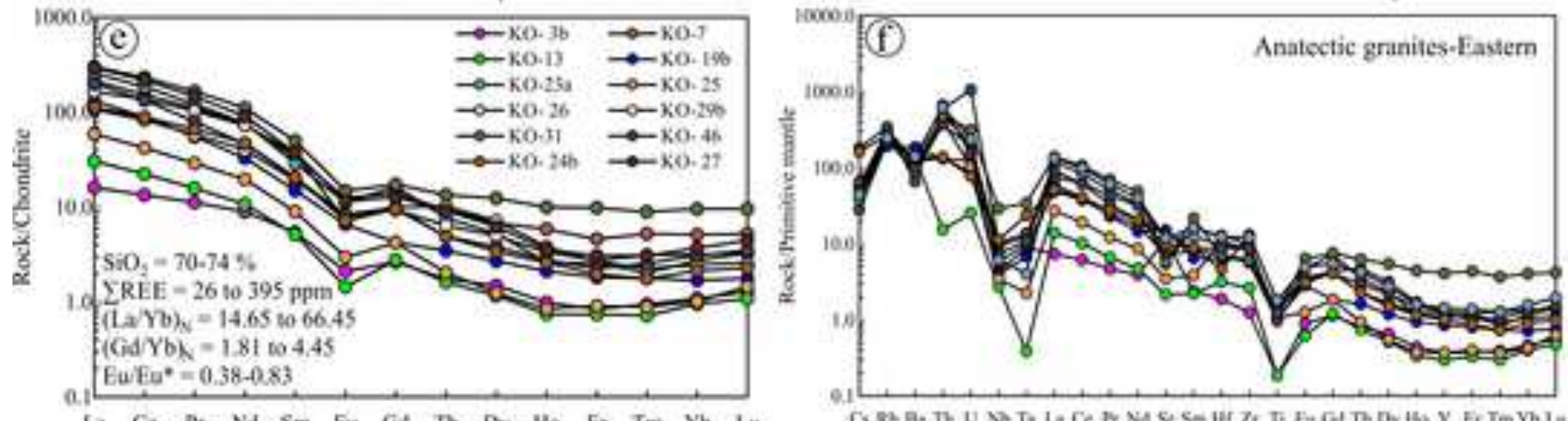

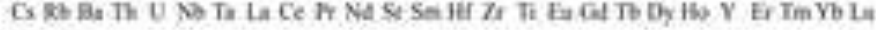
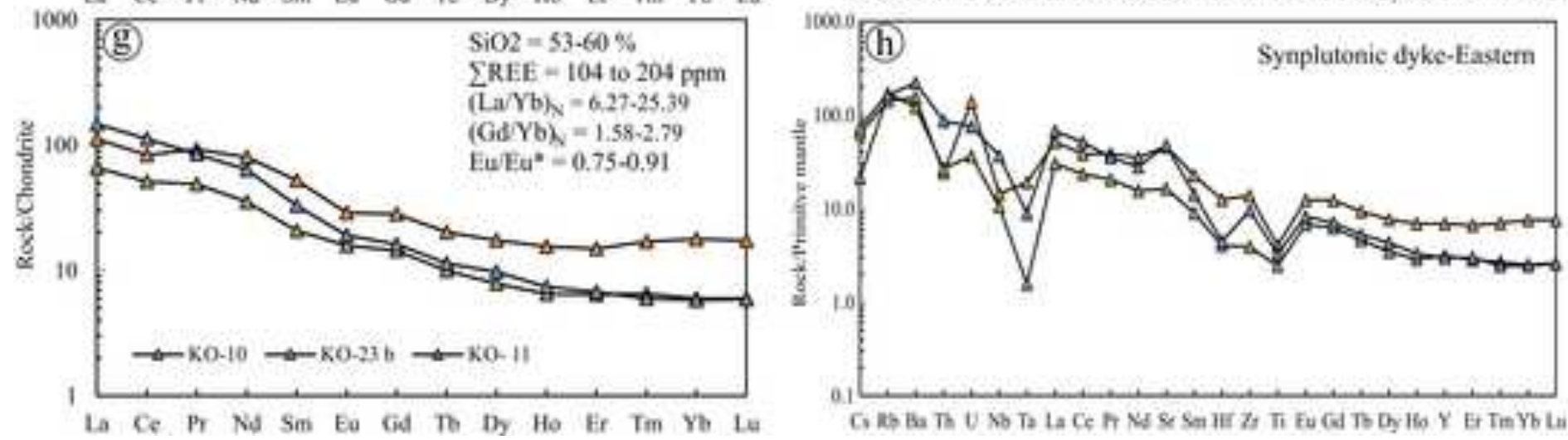

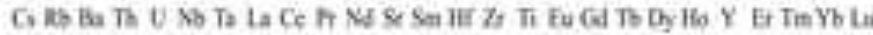


Click here to download high resolution image

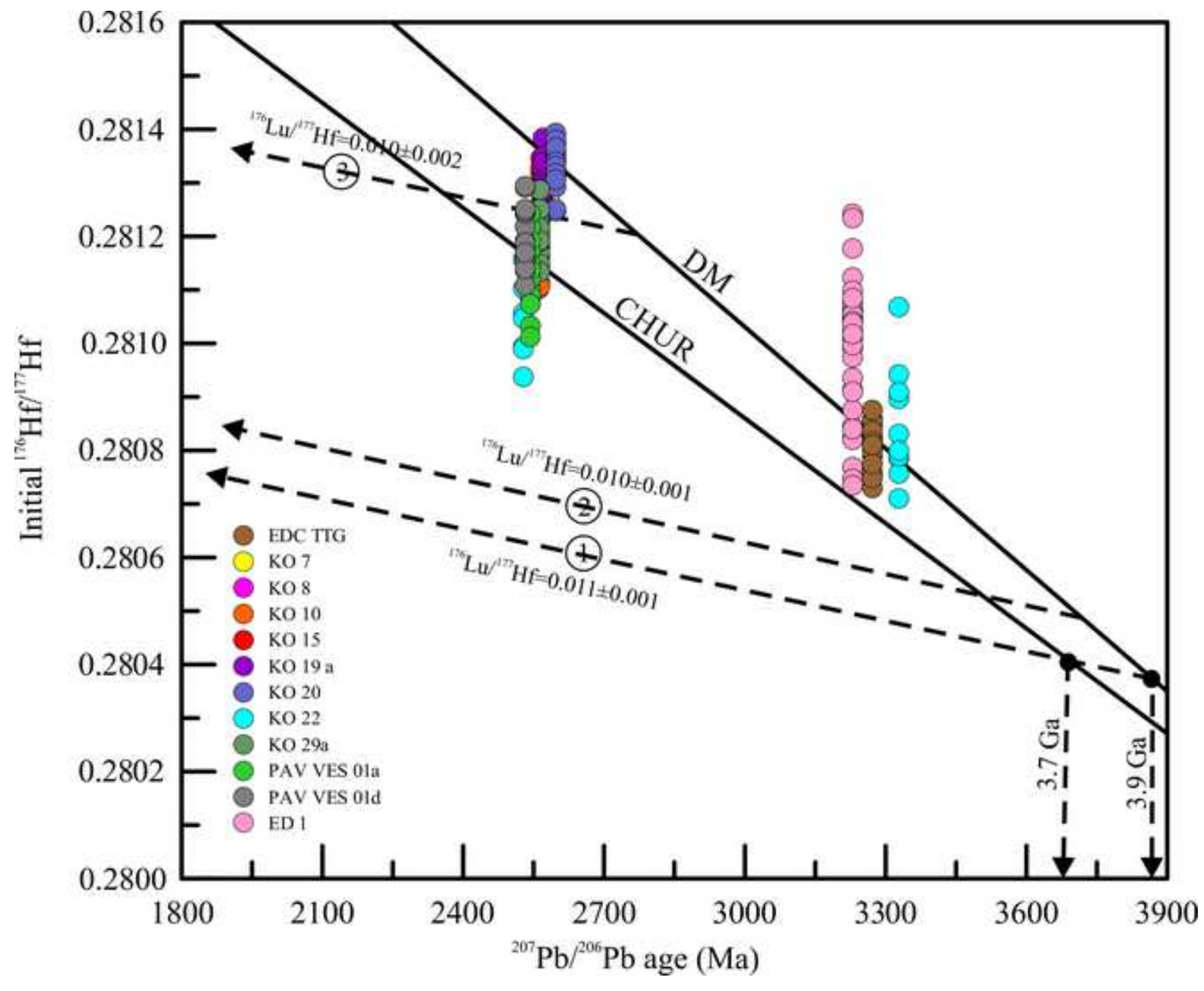




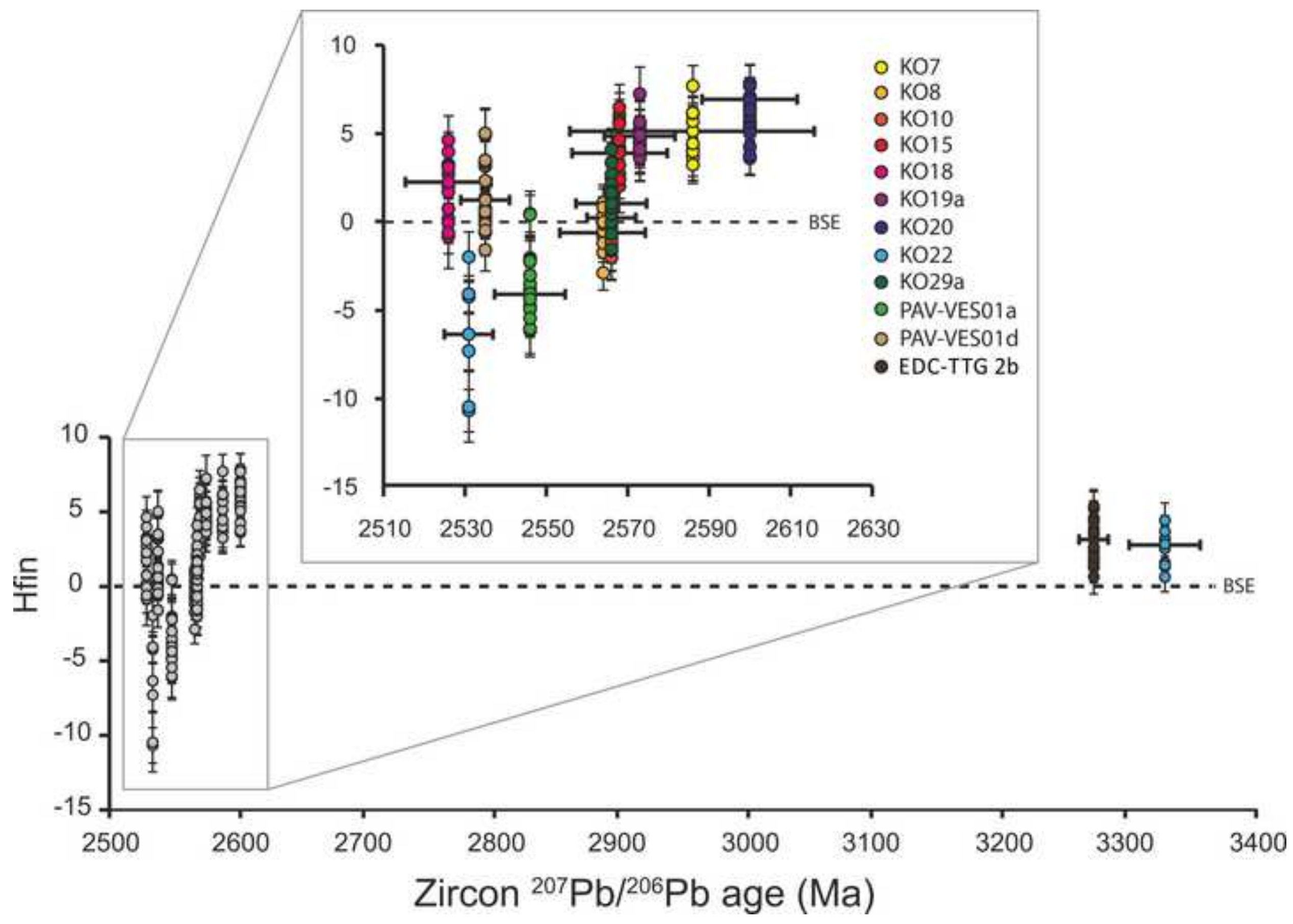




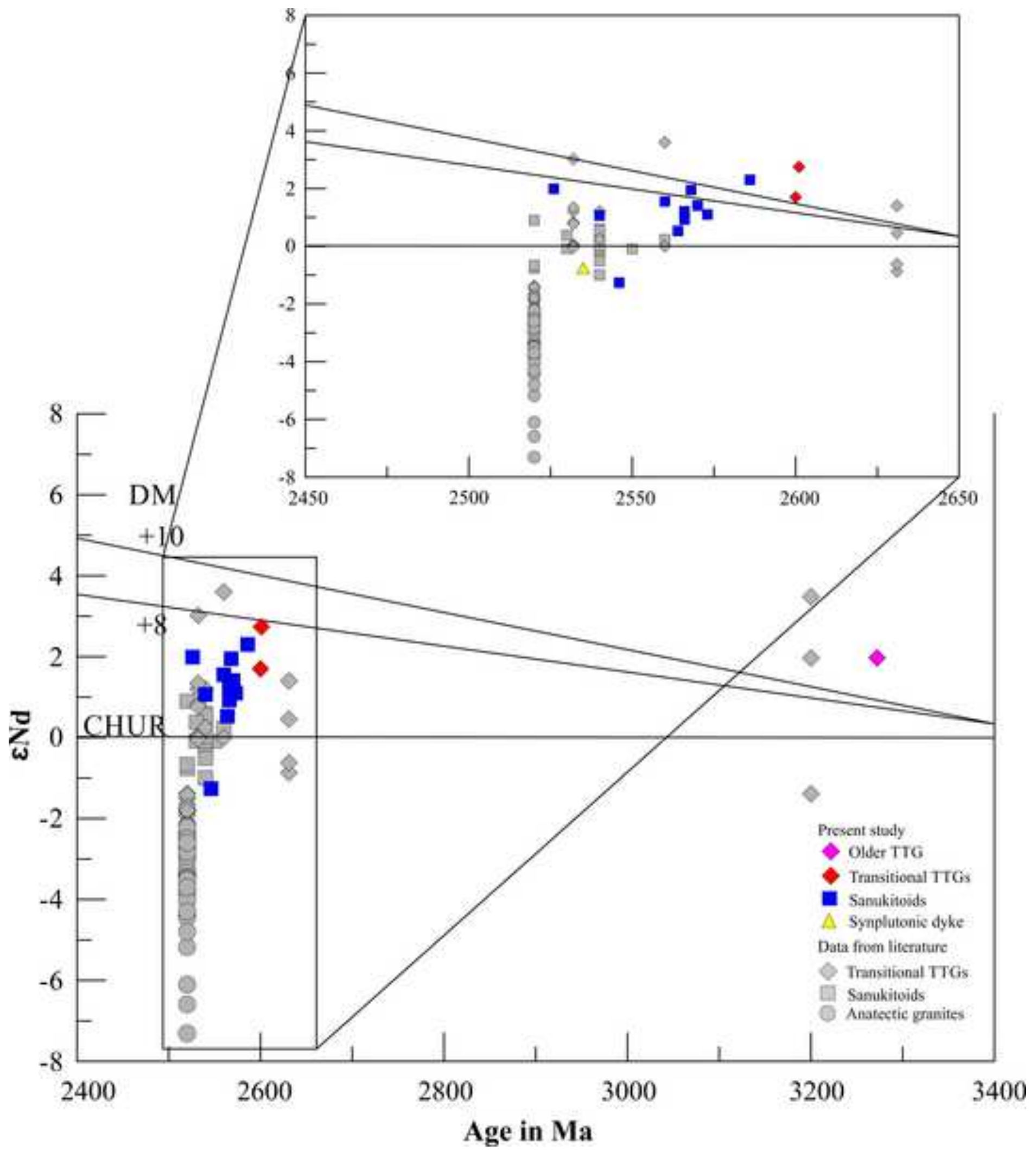


Transitional TTGs

Sanukitoids

Anatectic granites

$\triangle$ Synplutonic dyke

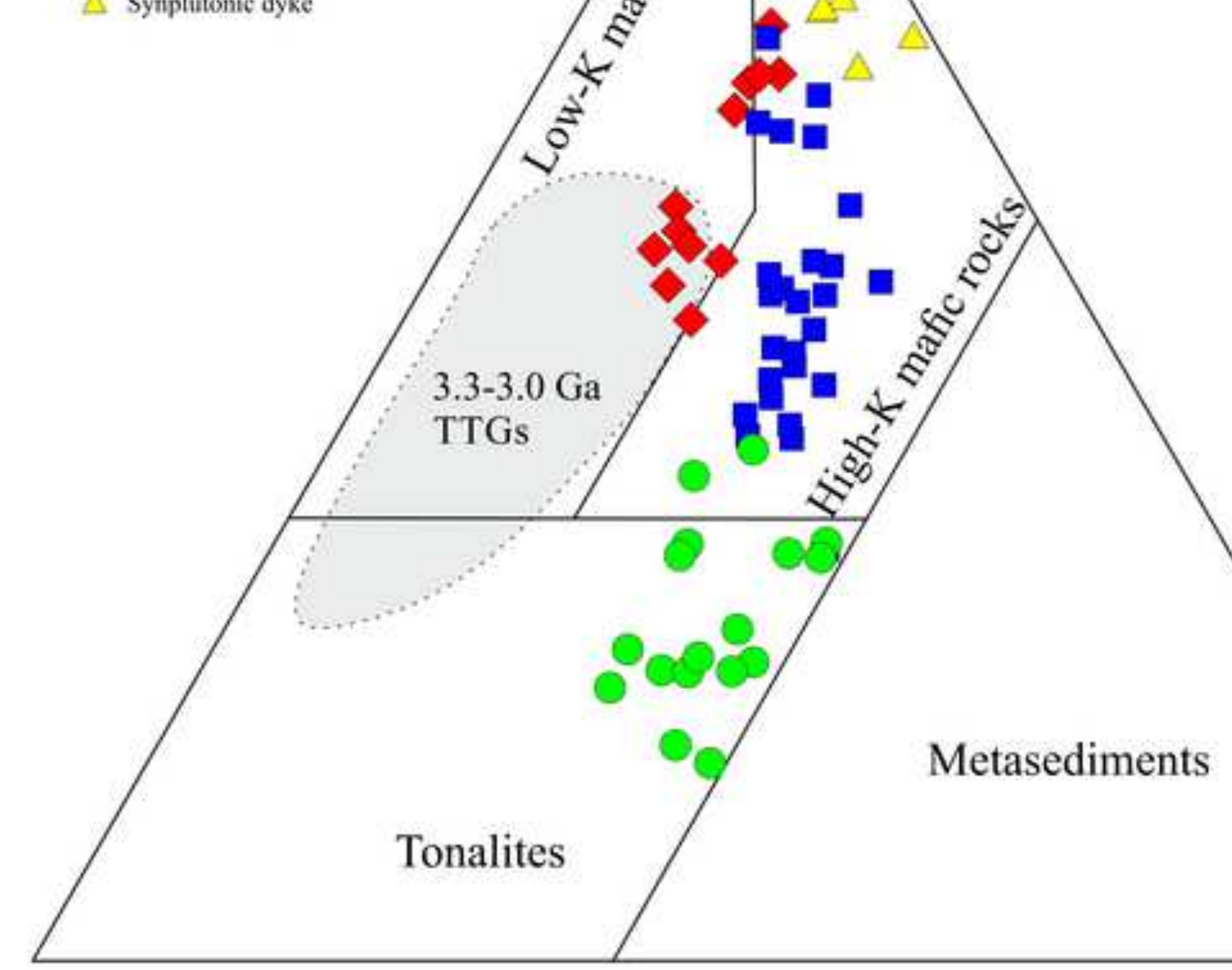




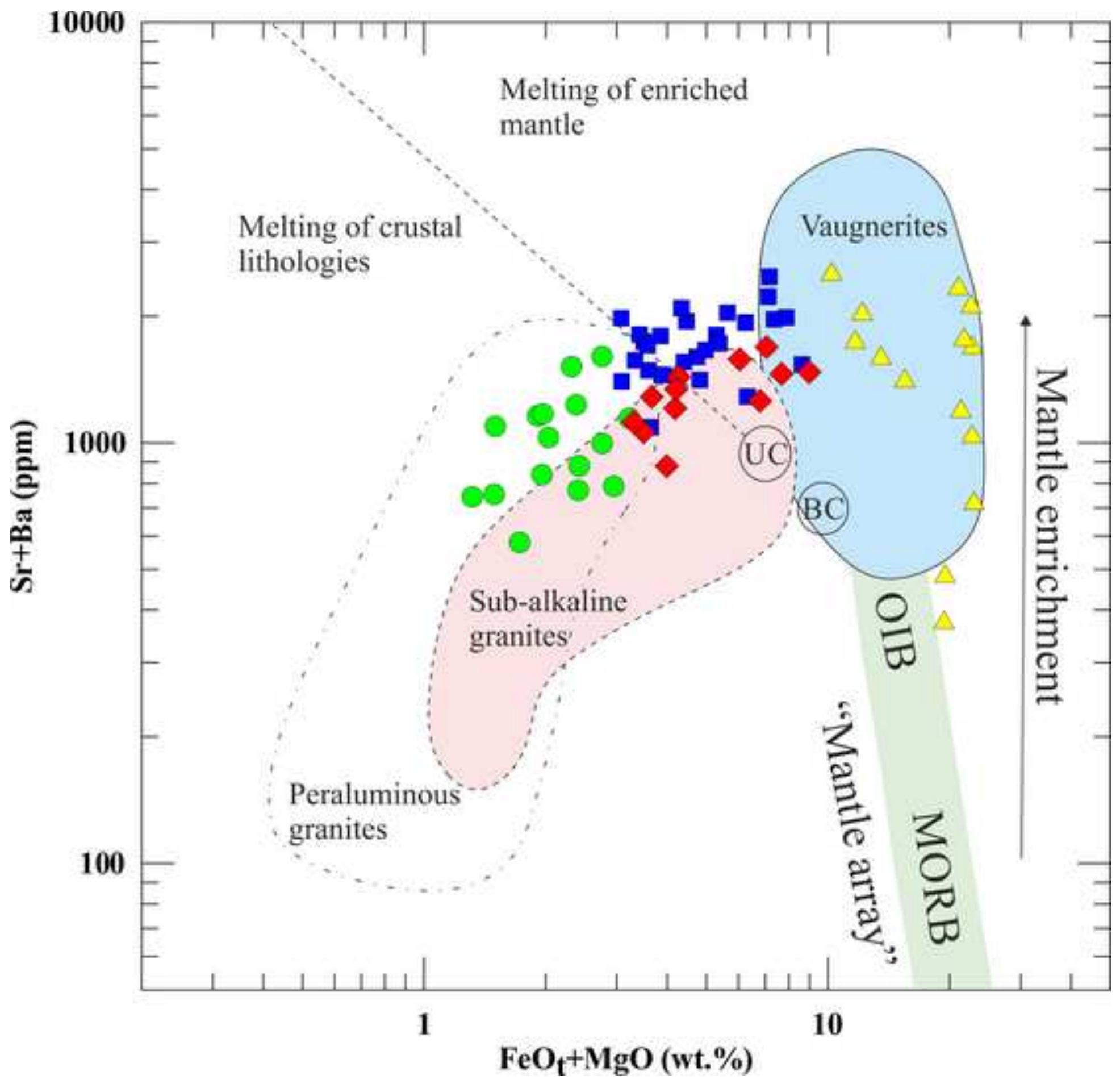




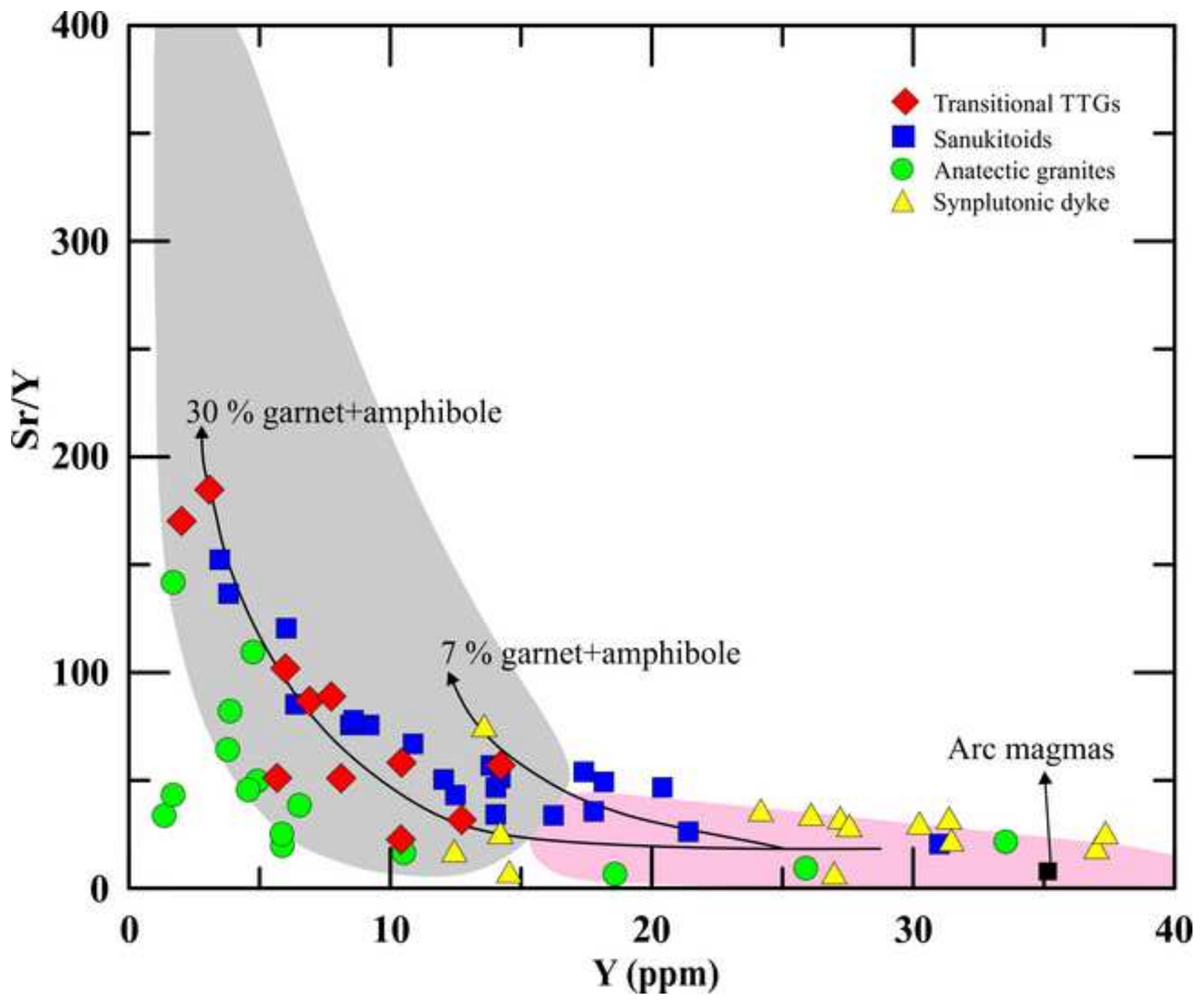


Click here to download high resolution image

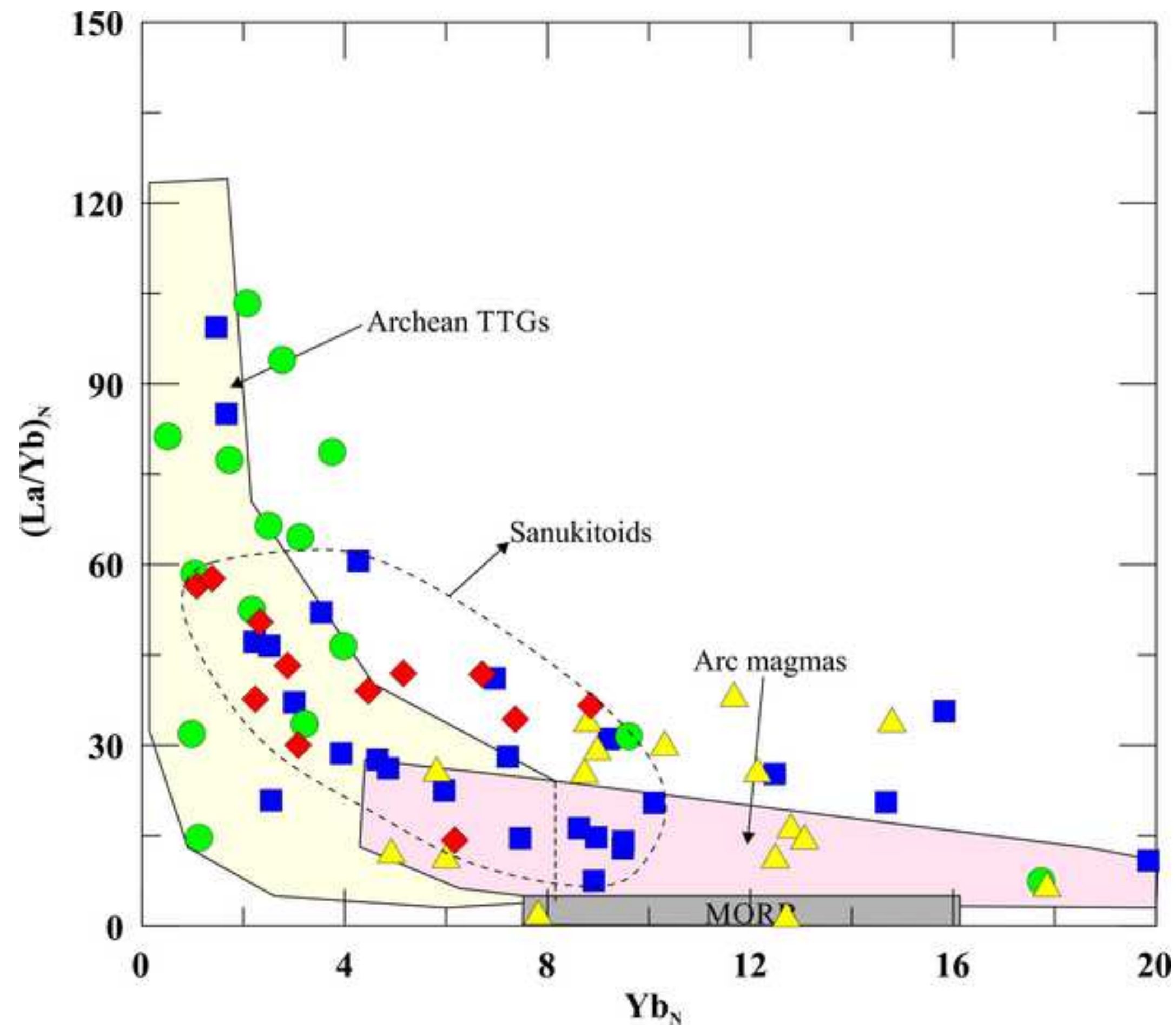




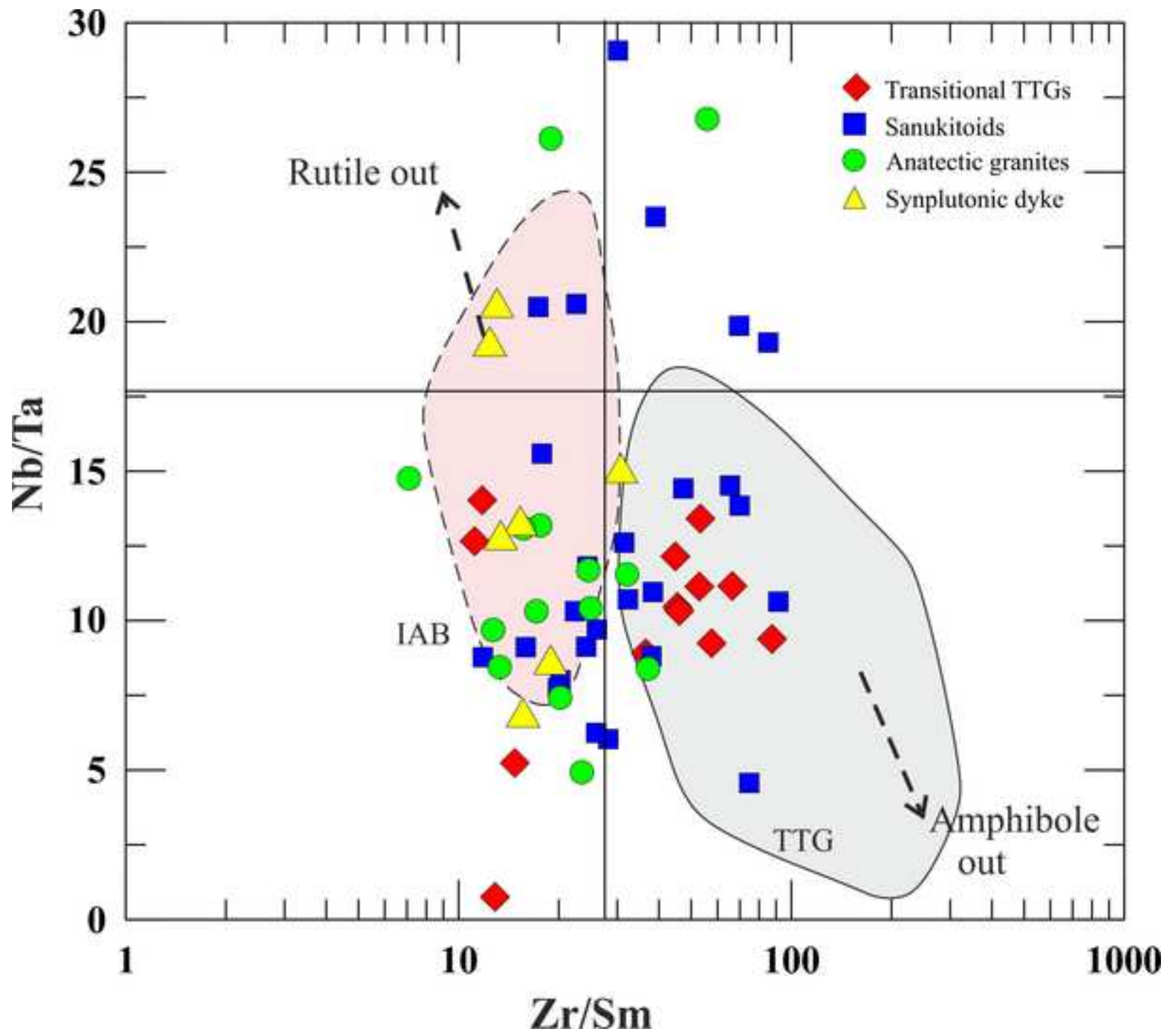




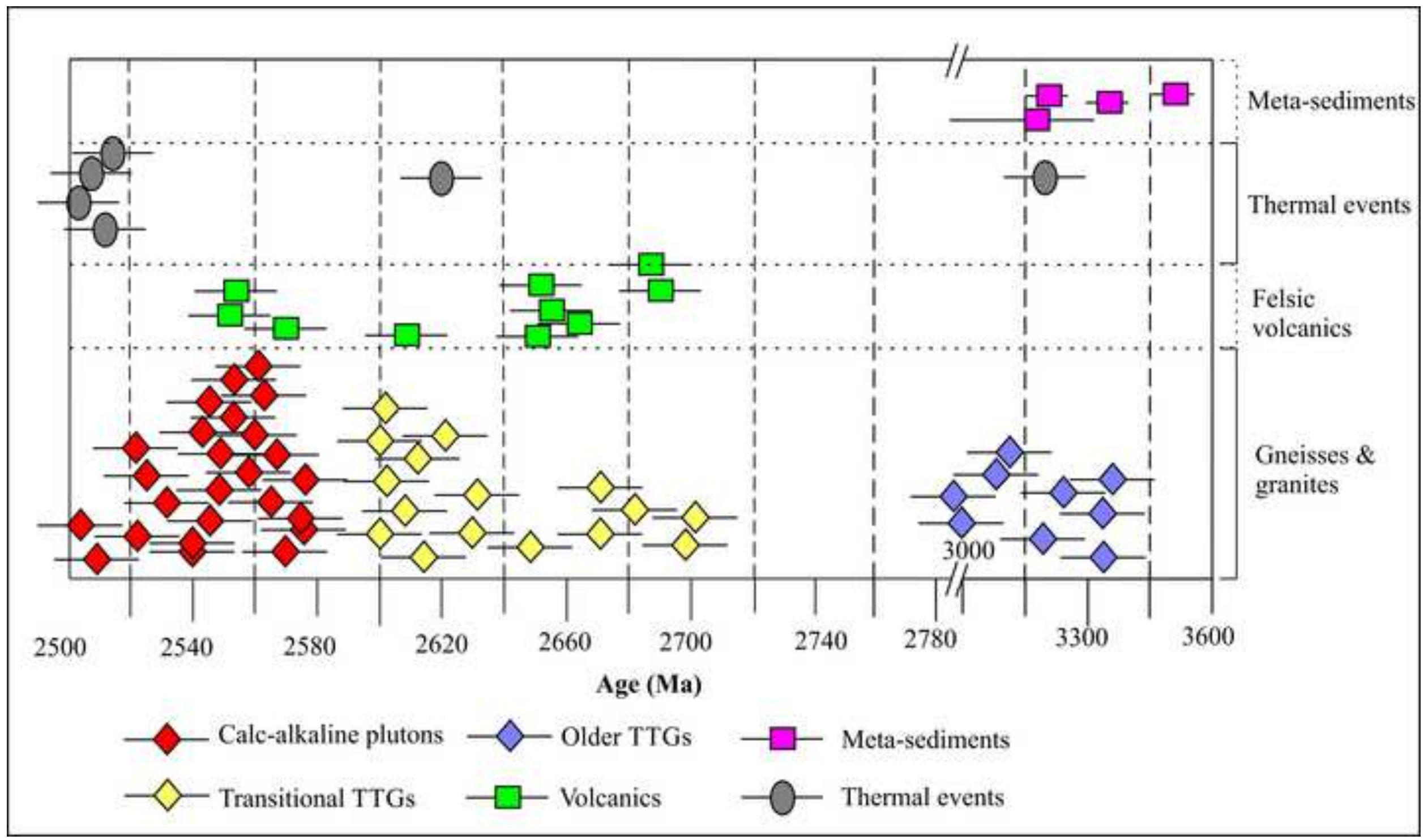


Click here to download high resolution image

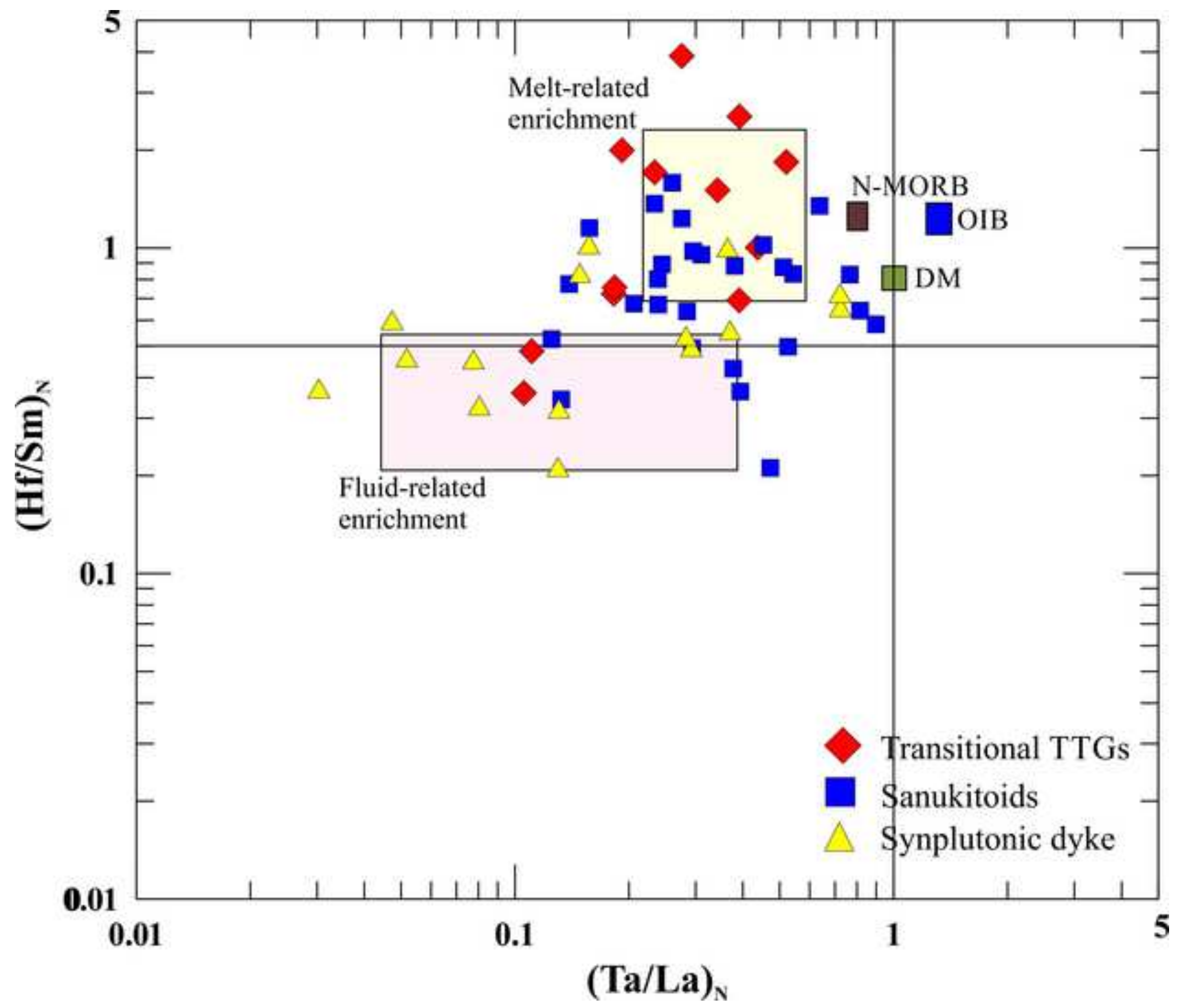

$(\mathrm{Ta} / \mathrm{La})_{\mathrm{N}}$ 


\section{Click here to download high resolution image}
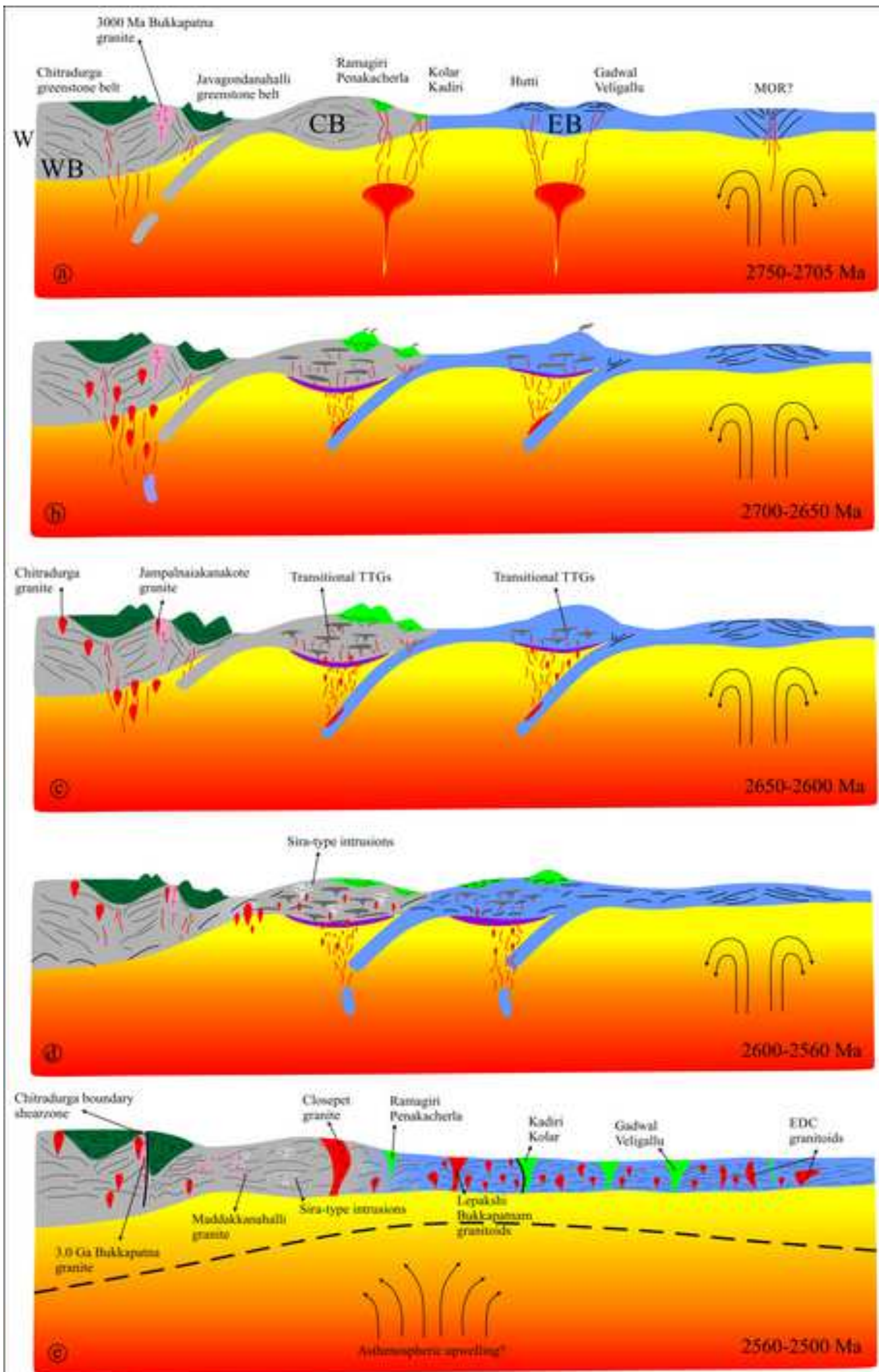